\begin{tabular}{|c|c|c|}
\hline Beitr. Ent. & Keltern & ISSN 0005-805X \\
\hline $\mathbf{5 8}(2008) 1$ & S. $15-95$ & 15.07 .2008 \\
\hline
\end{tabular}

\title{
Xiphydriidae of the Philippines, Insular Malaysia, Indonesia, Papua New Guinea, New Caledonia, and Fiji
}

\section{(Hymenoptera)}

With 121 figures

\section{DAVID R. SMITH}

\section{Summary}

Woodwasps of the family Xiphydriidae from the Philippines, insular Malaysia, Indonesia, Papua New Guinea, New Caledonia, and Fiji are reviewed. Twenty-six species in six genera are keyed, described, and illustrated. Two species are recorded from the Philippines, three species from insular Malaysia, eight species from Indonesia, nine species from Papua New Guinea, four species from New Caledonia, and one species from Fiji. Taxa described are Lissoxiphyda, n. gen., L. kiunga, n. sp. (Papua New Guinea), L. lucida, n. sp. (Papua New Guinea), L. morobe, n. sp. (Papua New Guinea), L. rufipes (F. SмIтH, 1859), n. comb. (Indonesia: Aru), L. shinoharai, n. sp. (Indonesia: Sulawesi), L. simbai, n. sp. (Papua New Guinea), L. tripotini, n. sp. (New Caledonia); Calexiphyda, n. gen., C. blanki, n. sp. (New Caledonia), C. caledonia, n. sp. (New Caledonia), C. crocea, n. sp. (New Caledonia); Indoxiphia MaA, 1949, I. darlingi, n. sp. (Indonesia: Kalimantin), I. falcata, n. sp. (Papua New Guinea: New Ireland), I. fijiensis, n. sp. (Fiji), I. laeviceps (F. SMITH, 1861) (Indonesia: Ambon, Buru; Papua New Guinea), I. maai, n. sp. (Papua New Guinea), I. papuaensis, n. sp. (Papua New Guinea), I. quadricincta (Benson, 1935) (Indonesia: Java), I. schiffi, n. sp. (Papua New Guinea), I. sumatra, n. sp. (Indonesia: Sumatra); Obesaxiphyda, n. gen., O. banahao, n. sp. (Philippines), O. borneensis (RoHwer, 1921), n. comb. (Malaysia: Sabah); Hyperxiphia MAA, 1949, H. cyanea (MocsÁRY, 1891) (Indonesia: Java), H. flavicornis (Rohwer, 1921), n. comb. (Malaysia: Sabah), H. sulawesi, n. sp. (Indonesia: Sulawesi); Lataxiphyda, n. gen., L. erythropus (Cameron, 1903), n. comb. (Malaysia: Sarawak), L. paraerythropus, n. sp. (Malaysia: Selangor), L. pyrura (RoHwer, 1921), n. comb. (Philippines). Two males for which names were proposed are placed as unassociated in their respective genera, Calexiphyda novacaledonica (Jennings and Austin, 2007), n. comb., and Indoxiphia testacea (Mocsáry, 1900), n. comb. Cingalixiphia MAA, 1949, is a new synonym of Indoxiphia MAA, 1949, and Palpixiphia MaA, 1949, is a new synonym of Hyperxiphia MAA, 1949. Hyperxiphia formosana (Enslin, 1911) and Obesaxiphyda heritierae (RoHwer, 1921) are new combinations.

\section{Zusammenfassung}

Die Schwertwespen (Xiphydriidae) der Philippinen, der Malaysischen Inseln, Indonesiens, PapuaNeuguineas, Neukaledoniens und der Fiji-Inseln werden revidiert. Sechsundzwanzig Arten aus sechs Gattungen werden beschrieben, abgebildet, und für diese ein Bestimmungsschlüssel erstellt. Zwei Arten werden von den Philippinen nachgewiesen, drei von den Malaysischen Inseln, acht aus Indonesien, neun von PapuaNeuguinea, vier aus Neukaledonien und eine von den Fiji-Inseln. Die behandelten Taxa sind: Lissoxiphyda, n. gen., L. kiunga, n. sp. (Papua-Neuguinea), L. lucida, n. sp. (Papua-Neuguinea), L. morobe, n. sp. (PapuaNeuguinea), L. rufipes (F. SмIтH, 1859), n. comb. (Indonesien: Aru), L. shinoharai, n. sp. (Indonesien: Sulawesi), L. simbai, n. sp. (Papua-Neuguinea), L. tripotini, n. sp. (Neukaledonien); Calexiphyda, n. gen., C. blanki, n. sp. (Neukaledonien), C. caledonia, n. sp. (Neukaledonien), C. crocea, n. sp. (Neukaledonien); Indoxiphia MAA, 1949, I. darlingi, n. sp. (Indonesien: Kalimantan), I. falcata, n. sp. (Papua-Neuguinea: Neuirland), I. fijiensis, n. sp. (Fiji), I. laeviceps (F. SмIтн, 1861) (Indonesien: Ambon, Buru; PapuaNeuguinea), I. maai, n. sp. (Papua-Neuguinea), I. papuaensis, n. sp. (Papua-Neuguinea), I. quadricincta 
(Benson, 1935) (Indonesien: Java), I. schiffi, n. sp. (Papua-Neuguinea), I. sumatra, n. sp. (Indonesien: Sumatra); Obesaxiphyda, n. gen., O. banahao, n. sp. (Philippinen), O. borneensis (Rohwer, 1921), n. comb. (Malaysia: Sabah); Hyperxiphia MAA, 1949, H. cyanea (MocsárY, 1891) (Indonesien: Java), H. flavicornis (Rohwer, 1921), n. comb. (Malaysia: Sabah), H. sulawesi, n. sp. (Indonesien: Sulawesi); Lataxiphyda, n. gen., L. erythropus (CAMEron, 1903), n. comb. (Malaysia: Sarawak), L. paraerythropus, n. sp. (Malaysia: Selangor), L. pyrura (RoHwer, 1921), n. comb. (Philippinen). Zwei nicht genauer deutbare Männchen, für die bereits Namen existieren, werden den folgenden Gattungen zugeordnet: Calexiphyda novacaledonica (Jennings und Austin, 2007), n. comb., und Indoxiphia testacea (Mocsáry, 1900), n. comb. Cingalixiphia MaA, 1949, ist ein neues Synonym von Indoxiphia MaA, 1949, und Palpixiphia MaA, 1949, ein neues Synonym von Hyperxiphia MAA, 1949. Hyperxiphia formosana (Ensurn, 1911) und Obesaxiphyda heritierae (RoHWER, 1921) sind neue Kombinationen.

\section{Key Words}

Symphyta, Xiphydriidae, woodwasps, southeastern Asia, Indo-Australia, Philippines, insular Malaysia, Indonesia, Papua New Guinea, New Caledonia, Fiji.

\section{Introduction}

Xiphydriidae occur in most major regions of the world, except subsaharan Africa. Their distinctive, elongate, cylindrical bodies, dome-shaped heads, and long "necks" make them a curious topic. SмITH (1978) listed 94 species in 22 genera, but several genera and 16 species have been described subsequently for a current total of 28 genera and 120 species (TAEger \& Blank 2006). Species of the Nearctic and Palearctic regions are relatively well known, but the tropical fauna, though rich in diversity, is unexplored. Specimens are not commonly collected in the tropics, and many species are known from one or a few specimens. When found, because of their rarity and peculiar morphology, each specimen often stimulates the topic of a separate publication.

Here, I review the species of the Philippines, the Malaysian states in northern Borneo, Indonesia, Papua New Guinea, and the islands of New Caledonia and Fiji. Only ten species previously have been described from this region, one from the Philippines, three from insular Malaysia, four from Indonesia, one from Papua New Guinea, and one from New Caledonia. Since about 1970 when this study was initiated, I have accumulated only an additional 50 specimens from this region. Progress is slow, and the probability of obtaining additional material within the foreseeable future is obscure; thus, I feel a review is in order to provide a basis for future work on the xiphydriid fauna of this region.

Where known, larvae of xiphydriids are wood borers in weakened or dying limbs of woody plants. Those of the Nearctic and Palearctic Xiphydria Latreille bore in limbs of Acer, Alnus, Betula, Carpinus, Prunus, Salix, Tilia, and other deciduous trees (Sмітн 1976, 1978). Little is known of Neotropical species, except one, Derecyrta araucariae Meске (Меске et al. 2001), which was reared from dead limbs of Araucaria angustifolia (Bertol.) Kuntze (Araucariaceae) in southern Brazil. Species in Chile have been taken in Nothofagus and Fitzroya forests (Sмiтн 1988, 1995a). In New Zealand, Moaxiphia duniana (Gourlay) has been recorded from Nothofagus fusca (Hook.F) and Nothofagus menziesii (Ноок.F) (Fagaceae) and M. decepta (F. SмIтH) from Coprosma robusta Raoul (Rubiaceae) (Valentine 1970). Nothing is known of the biology of the species treated herein, though Obesaxiphyda heritierae (RoHwER), a species related to O. borneensis (RoHwer) from insular Malaysia, was reared from "sundri," Heritiera fomes Buck. Ham. (Sterculiaceae) in India. Wood-boring habits in small limbs, however, are probably similar to those of Nearctic and Palearctic species. 
Four genera are recognized in the Neotropical Region (Sмiтн 1988). Prior to MaA (1949), six genus-group names were available for the Holarctic, Oriental, Indomalayan, and Australian fauna. MAA (1949) added ten new genus-group names, BENSON (1954) three more, RieK (1955) added one for Australia, SAINI and SINGH (1987) added one for India, and WIE and XIaO (1999) and WIE (2002) proposed five more from China. Thus, there are 26 genus-group names that potentially could apply to specimens in the area under study. The ten species previously described from this region have been placed in six different genera, mostly by MAA (1949), who based placement of many on original descriptions. Here, I recognize 26 species in six genera from the Philippines and Indonesia east to Fiji, plus two genera from Australia and New Zealand which are not treated further.

All species treated here belong to the Xiphydriinae of Benson (1954). The other subfamily, Derecyrtinae is Neotropical and Australian. Four genera and 20 species occur in the Neotropical Region (Sмiтh 1988, 1995a, 1995b, 2004), but only one genus with one species of Derecyrtinae is Australian, Austrocyrta australiensis Riek (Riek 1955, Jennings et al. 2007). The Derecyrtinae are recognized by the long pronotum, from above shallowly excavated in front with the excavation shorter than the medial length of the pronotum; the mesoscutellum, which has a dorsal area margined by a carina and with a prominent tubercle near its apex; and the femora scarcely swollen. The Xiphydriinae have the pronotum deeply excavated in front (Figs 45, 67, 99), the excavation much longer than the medial length of the pronotum; the mesoscutellum rounded at its apex and lacking a dorsal area defined by a carina and lacking a prominent tubercle near its apex; and the femora are more swollen. All Derecyrtinae share the long, 6- or 7-segmented maxillary palpi, but this character is shared also by Rhysacephala Benson of Australia, Moaxiphia MAA of New Zealand, Lissoxiphyda, n. gen., from Indonesia and Papua New Guinea, and Calexiphyda, n. gen., from New Caledonia, described here in Xiphydriinae. All other genera have the maxillary palpi reduced, usually 4- or 5-segmented, and much shorter and more slender than the labial palpi.

\section{Materials and Methods}

Acronyms used in the text are as follows: AEIC, American Entomological Institute, Gainesville, Florida, USA; BMNH, The Natural History Museum, London, U.K.; BPBM, Bernice P. Bishop Museum, Honolulu, Hawaii, USA; CNC, Canadian National Collection of Insects, Ottawa; DEI, Deutsches Entomologisches Institut, Müncheberg, Germany; RMNH, Nationaal Natuurhistorische Museum ("Naturalis"), Leiden, The Netherlands; NHMH, Natural History Museum, Budapest, Hungary; NSMT, National Museum of Science and Nature, Tokyo, Japan; OUMNH, Hope Entomological Collections, Oxford University, Oxford, U.K; MNHN, Muséum National d'Histoire Naturelle, Paris, France; ROME, Royal Ontario Museum, Toronto, Canada; TURKU, Biological Collection of Åbo Akademi University, Turku, Finland; UCDC, University of California, Davis, USA; USNM, National Museum of Natural History, Smithsonian Institution, Washington, D.C., USA.

Morphological terminology follows Huber and Sharkey (1993). Auto-Montage systems were used for taking pictures.

This study is primarily based on females. Very few males are known, and there is considerable sexual dimorphism which prevents association of sexes from isolated specimens. Females and males show drastic differences in color, as well as antennal structure, tarsal claws, and even to some degree in sculpturation. A category "unassociated males" is provided at the end of some genera to include some males for which names were proposed and for some males which I have examined that cannot be placed.

Types of all species have been examined except for Rhysacephala novacaledonica JenNings and Austin (see Calexiphyda). 


\section{Results}

\section{Character Assessment and Generic Classification}

MAA's (1949) treatment of the world fauna is the most recent comprehensive study. BENSON (1954) refined this classification recognizing two subfamilies, synonymizing many of Maa's subfamilies and tribes. It is beyond the scope of this study to evaluate all the genus-group names but each has been considered in this study and I have found it necessary to propose several new genera.

As did Benson (1954), I have difficulty using Maa’s generic classification and have had difficulty in placing the species treated here into the current generic framework. This is because much of MAA's (1949) classification is based on the maxillary and labial palpi, but these are difficult to see in many specimens, the number of segments are not always clear (e.g., some constrictions in segments may construe the actual number of segments), and there appears to be some variability such as that found in Xiphydria by Benson (1954).

Although the use of mouthparts may be valuable, I have combined other sets of characters to define genera and have divided the fauna into groups sharing primarily the following characters: Type of antenna, number of segments, length of pedicel; malar space; genal carina; occipital carina; labial palpus; maxillary palpus; sculpture of the head; sculpture of the thorax; type of tarsal claws; size of costal cell of the forewing; and presence or absence of cells Rs, $\mathrm{M}$, and $\mathrm{A}$ in the hind wing and shape of anal cell, if present, in the hind wing.

Head: Antennae of most species are filiform (Figs 13, 58, 92, 106, 109), sometimes slightly tapering toward the apex. Only those of Obesaxiphyda and females of Lataxiphyda have the basal part of the flagellum decidedly swollen (Figs 83, 87). The scape is usually slightly flattened and curved, much longer than the pedicel and about equal to the length of the first flagellomere. The pedicel may be about as broad as long to two times or more longer than broad; it is rather short in Lissoxiphyda (Fig. 19) and Lataxiphyda (Fig. 110) but longer in the other genera (Figs 54, 62). In Obesaxiphyda, the pedicel is laterally flattened (Fig. 83). The number of antennal segments varies from 14 to 22 and the antennal length is various; these are described under each species.

The number of segments and relative lengths and shapes of the maxillary and labial palpi were used by MaA (1949). These no doubt have some value, but these structures are variable and often difficult to interpret, and I have not relied entirely on them. In Rhysacephala, Moaxiphia, Lissoxiphyda, and Calexiphyda, the maxillary palpus is 7-segmented and twice or more the length of the 4-segmented labial palpus. In other genera, the maxillary palpus is considerably reduced, much more slender and only half as long or less than the length of the labial palpus. Otherwise, the palpi are often hidden, broken, and the segments difficult to distinguish, and I have not used them further. Sometimes there appears to be an impression, and it is difficult to tell if one or two are present, and also difficult to tell if previous authors counted these as one or two segments. Many of MAA's genera and some of those subsequently described rely heavily on the number of segments and shapes and relative lengths of the palpal segments. This applies to Nasoxiphia WeI (6-segmented maxillary palpus, 4-segmented labial palpus), Euxiphydria Semenov, and Carinoxiphia WeI (4-segmented maxillary palpus, 3 segmented labial palpus), Palpixiphia, Hyperxiphia MAA, and Megaxiphia WeI (5-segmented maxillary palpus and 4-segmented labial palpus), Paraxiphia MaA, Genaxiphia MaA, Dryxiphia MaA, Alloxiphia WeI, and Xiphydria (5-segmented maxillary palpus and 3-segmented labial palpus), and Heteroxiphia SAINI and Singh, Trixiphidia WeI, and Yangixiphia WeI (3-segmented maxillary palpus, 4-segmented labial palpus). Almost every combination deserves a separate genus. Variability such as the number of labial palpal segments as found in the abundant Xiphydria camelus (Linnaeus) by Benson (1954) 
have not been taken into consideration. All of these genera are very similar, and I suspect that they eventually will be reduced to only several groupings. For this study, Indoxiphia, Obesoxiphyda, Hyperxiphia, and Lataxiphyda have similar mouthparts, 4 or 5-segmented maxillary palpi and 3- or 4-segmented labial palpi, with the maxillary palpi reduced, and I do not subdivide them further by number of segments and relative lengths and shapes of the segments.

The malar space was sometimes used by MAA (1949), but BENSON (1954) was unsure of MAA's definition. In the malar area there is a depression (antennal groove), and BENSON interpreted the length of the malar space to be from the inner edge of this depression to the eye, not the outer (mandibular) edge of the groove. The length of the malar space and depth of the depression varies in the specimens studied. BENSON's interpretation is used here.

Eyes may be large and oval, in lateral view close to the posterior margin of the head (Figs 43, $49,65)$, or smaller and more rounded, farther removed from the posterior margin of the head (Figs 105, 111). In frontal view, the inner margins of the eyes may be subparallel or diverge; they are generally subparallel in Lissoxiphyda (Fig. 2), Obesaxiphyda (Figs 82, 86), Hyperxiphia (Figs 96, 100), and Lataxiphyda (Fig. 105), but mostly diverge below in Indoxiphia (Figs 66, 70) and some Calexiphyda (Fig. 34).

The genal carina is absent in Indoxiphia, the gena bearing a number of carinae in its place (Fig. 43). In other genera, the genal carina is present though may be faint, present only on the lower part of the gena or distinct and extending to the top of the eye.

All genera have an occipital carina. It may be very narrow and indistinct to very broad. In Calexiphyda, it is more broadly developed laterally than dorsally (Fig. 35).

In most genera, the gena and vertex of the head are smooth and shining, sometimes with some punctures. In several genera, Dryxiphia MaA, Gryponeura Benson, Platyxiphydria Takeuchi, Rhysacephala Benson, and Xiphydriola Semenov, the genae and vertex are dull with dense microsculpture and or cross striations. Except for Rhysacephala in Australia, these genera do not occur in the region under study and are not treated further. A faint median longitudinal groove is present on the vertex only in species of Rhysacephala and Lissoxiphyda.

Thorax: The length vs. the width of the "prepisterna" of MAA (= propleuron or "neck") is used in one couplet of MAA's key to separate two groups of genera. I do not see that this is useful. Specimens apparently belonging to certain genera will go to the wrong part of the key. BENSON (1954) was skeptical of the use of this character as well, and it is not used here.

Wing venation may be erroneously used to support genera. Many xiphydriids are described from single specimens, and aberrations in wing venation commonly occur. Examples for such variation have been illustrated by Zirngiebl (1939) for Xiphydria prolongata (Geoffroy) and by JANSEN (1987) for Konowia betulae (Enslin) and K. megapolitana (Brauns). Thus, it is not good to use venation unless series of specimens are available to determine the stability of the presence or absence, fading out, or position of veins. In the forewing, the fading out of vein $2 \mathrm{~A}+3 \mathrm{~A}$ apically, and in the hind wing the presence or absence of cells Rs and $M$ are occasionally used. BENSON (1954) separated his Xiphidiaphora from all other genera of Xiphydriinae by the absence of $2 \mathrm{r}$ in the forewing. In Lissoxiphyda, all specimens lack cells Rs, M, and most lack cell A in the hind wing, and I feel this is fairly reliable. In Indoxiphia, one species lacks cell Rs in the hind wing; and in Obesaxiphyda, some specimens lack the hind wing cells, others have all or some of them, and this may even occur in wings on the same individual. The costal cell of Lataxiphyda is very broad (Figs 110, 120), five or more times broader than the width of the costa; in other genera the costal cell is very narrow (Fig. 69), not much more than the width of the costa. The shape of the anal cell of the hind wing, if present, may differ. In most genera, vein $1 \mathrm{~A}$ is straight, the apex of vein 
2A sharply turns up at its apex to meet $1 \mathrm{~A}$ and thus the cell appears almost truncate at its apex (Fig. 69). In Lataxiphyda, vein $1 \mathrm{~A}$ is more curved, and veins $1 \mathrm{~A}$ and $2 \mathrm{~A}$ slope evenly toward the apex, giving the apex a more rounded appearance (Figs 110, 121).

The sculpturation of the thorax differs between genera and species. In general, parts of the thorax, e.g., mesoscutal lateral lobes, mesoscutellum, and or mesepisternum, of Lissoxyphyda are smooth and shining without sculpture, whereas most other genera have densely reticulate or punctate patterns.

Tarsal claws are extremely variable. Females of Indoxiphya and one species of Lissoxiphyda lack an inner tooth on the middle and hind or only the hind tarsal claws (Fig. 57). Males of Indoxiphyia and species of all other genera have a short or long inner tooth on all tarsal claws (Figs 38, 104). The inner tooth varies in size, and the distinction of "apically bifurcate" and "minor tooth" by MAA (1949) is inadequate because there are all degrees of sizes. Males of Obesaxiphyda and Lataxiphyda have an unusually long inner tooth, being almost the same length as the outer tooth and closely appressed to the outer tooth (Fig. 119).

I have included the length of the hind basitarsus vs. the length of the remaining tarsal segments combined. This may be of use in species separation.

Abdomen: I have included measurements of the sheath vs. valvifer 2 vs. the hind tibia and the length of the basal plates vs. the length of the second tergite, which may be of use in some species separation. In general, the abdomen is shining, commonly dulled with microsculpture especially on the first and second tergites. Differences in female ovipositors and male genitalia need to be explored. Too many specimens, however, are known only from old type material and could not be examined without possible destruction.

Using many of these characters, I have grouped the species within the scope of this study as follows:

(1) Species with 7-segmented maxillary palpus, with length much longer than labial palpus. Although I limit the value and prefer not to use the palpi as a sole generic character, several groups of species from Australia, New Zealand, eastern Indonesia, Papua New Guinea, and New Caledonia share the long 7-segmented maxillary palpus, which is slender and two times or more longer than the labial palpus. Genera included are Rhysacephala Benson, Moaxiphia MAA, Calexiphyda, n. gen., and Lissoxiphyda, n. gen. I have examined the New Zealand Moaxiphia and only several specimens of the Australian Rhysacephala, the two genera that are not further treated here. MAA (1949) treated this as a single genus, Moaxiphia. Later Benson distinguished between the New Zealand and Australian species, and proposed Rhysacephala for the Australian species, Moaxiphia being restricted to the two species that occur in New Zealand. There are some significant differences between these and the specimens from Papua New Guinea and eastern Indonesia and New Caledonia, and I am placing the latter in different genera. The Australian members have a densely punctate, dull head (vs. very shining and without sculpture), a small occipital carina (vs. large, flangelike laterally), and are very small, and with the full complement of veins and cells in the wings. RieK (1955) described another genus, Austrocyrta, from Australia, placed in the Neotropical tribe Derecyrtinae. It lacks vein $2 \mathrm{r}$ in the forewing and is not considered here because all species possess this vein.

(2) Species with short maxillary palpi and hind or middle and hind claws of female simple, fore claws with inner tooth. Available names for this group are Xiphydriola SEmenov, Cingalixiphia MAA, and Indoxiphia MaA. Xiphydriola has all claws simple, the entire head sculptured, 2r absent in the forewing, and cell Rs open in the hind wing. Cingalixiphia and Indoxiphia were described as subgenera of Indoxiphia by MAA, but treated as genera by BENSON who gave characters separating 
them. Both MAA and Benson separated Indoxiphia by having only the hind claw simple and Cingalixiphia by having both middle and hind claws simple. Contrary to the concepts of MAA and Benson, however, the type species of Indoxiphia, Xiphydria quadricincta Benson, has both middle and hind claws simple. Thus, the distinction of the two genera disintegrates and the two must be considered the same. I am therefore treating all species with the hind claws simple and species with both the middle and hind claws simple as one genus, Indoxiphia. I choose Indoxiphia over Cingalixiphia because I have examined the type species of the latter. Nine species are here placed in Indoxiphia; two have only the hind claws simple, the rest that both the middle and hind claws simple. This assemblage of species also has the following in common: Absence of a distinct, prominent genal carina, the carina on the lower half of the gena being replaced by 4 or 5 or more prominent ridges; labial palpus 3 or 4-segmented, maxillary palpus 4 or 5 -segmented and always shorter than the labial palpus (when this can be determined); usually antennae rather short, 13-15 segmented; wings mostly with the full complement of cells and veins.

(3) Species with short maxillary palpi and all claws of both sexes with inner tooth. This assemblage of species has, in general, a distinct genal carina, at least on the lower third or quarter of the gena or sometimes extending to the top of the eye, that is larger and well separated from any associated ridges on the genae; maxillary and labial palpi various, but maxillary palpi sometimes up to 6-segmented but shorter than the labial palpus; antennae usually longer and 17-23 segmented; and hind wings sometimes lacking cells Rs and/or $\mathrm{M}$ in the hind wing. I further break this down as follows:

Species with all claws with inner tooth, maxillary palpus 4- or 5-segmented and shorter than labial palpus, and vertex smooth and shining: This group includes the genera Hyperxiphia MAA, Paraxiphia MaA, Palpixiphia MaA, Xiphydria Latreille, Nasoxiphia MaA, Euxiphydria Semenov, Heteroxiphia SAINI and Singh, and apparently Carinoxiphia WeI, 1999, Megaxiphia WeI, 1999, Trixiphidia WeI, 1999, Xanxiphia WeI, 2002, and Alloxiphia WeI, 2002. I fail to see adequate differences between these genera other than mouthparts and am tempted to treat all species in this region in the oldest genus, Xiphydria. Most of the remaining species, however, fall into the currently recognized genus Hyperxiphia because of the 4-segmented labial palpus, although, as Benson (1954) has shown, some species of Xiphydria also may have, or apparently have a 4-segmented labial palpus. Palpixiphia goes to the same couplet in MaA's key, where he separates it from Hyerxiphia by the apically bifurcate tarsal claws (difficult to determine because the inner teeth are all sizes), short apical segment of the maxillary palpus (of different lengths), and lengths and position of the segments of the labial palpus (variable in the species treated here).

Other recognized genera have a 3-segmented labial palpus, 3-or 4-segmented maxillary palpus and variously shaped claws. Heteroxiphia was proposed by SAINI and SINGH (1987) because of the 3-segmented maxillary palpus, and WeI (2002) proposed Trixiphidia and Yangixiphia, both close to Heteroxiphia because of the 3-segmented maxillary palpus, but also with a 3-segmented labial palpus.

Other genera differ from the above mentioned by having the temples behind the eyes sculptured. This character is shared by Genaxiphia, Gryponeura, Platyxiphydria, and Dryxiphia. No species in the region under study belongs here and these genera are not treated further.

Apoxiphia MaA (treated as a synonym of Konowia by Benson 1954 and JANSEN 1987), Konowia Brauns, and Pseudoxiphydria ENSLIN (treated as synonyms of Xiphydria by Ross 1937 and TAEger et al. 2006) are European and have not been recorded elsewhere.

The following key to genera includes those recognized from the Philippines, Insular Malaysia, Indonesia, Papua New Guinea, Australia, New Zealand, New Caledonia, and Fiji. The Australian and New Zealand fauna are not treated further. 


\section{Key to Genera}

1. Medial length of pronotum long, equal to or slightly longer than depth of excavation of pronotal collar in front; mesoscutellum with tubercle near apex; vein $2 \mathrm{r}$ absent in forewing (Australia) Austrocyrta

Medial length of pronotum short, much shorter than depth of excavation of pronotal collar in front (Figs 46, 89, 99); mesoscutellum rounded at apex, without tubercle; vein 2r present in forewing (Figs 28, 69) 2

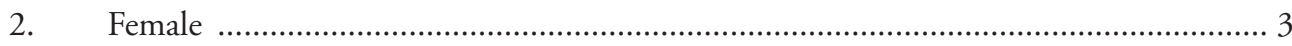

Male 11

3. Forewing costal cell broad, more than 2X width of costa (Figs 110, 120); head depressed above ocelli (Figs 106, 112) Lataxiphyda

Forewing costal cell narrow, not much wider than costa (Figs 28, 69); head rounded, without depression above ocelli (Figs 15, 24, 43, 87) ....................................................... 4

4. Hind or middle and hind claws simple (Fig. 55) ..................................................... 5

All claws with inner tooth (Fig. 102) ................................................................... 7

5. Maxillary palpus 7-segmented, almost twice length of labial palpus; vertex with medial longitudinal shallow furrow or row of punctures (Lissoxiphyda tripotini; New Caledonia) Lissoxiphyda (in part)

Maxillary palpus 4- or 5-segmented, about half length of labial palpus; vertex without median furrow or row of punctures .. 6

6. Antenna filiform, not enlarged basally (Figs 42, 47, 58); pronotum concave on sides; from above deeply emarginate (Fig. 46, 99) and deeply concave laterally Indoxiphia Antennal flagellum strongly enlarged basally (Figs 82, 87), tapering toward apex; pronotum convex on sides, from above shallowly emarginate (Figs 84, 89) and shallowly concave laterally Obesaxiphyda

7. Maxillary palpus 4- or 5-segmented, about half length of maxillary palpus .... Hyerxiphia Maxillary palpus 7-segmented, nearly twice length of labial palpus ... 8

8. Antennae close together, distance between antennal sockets much less than twice distance between antennal sockets and front of clypeus; antenna long, 25-segmented; genal carina absent (gena and vertex smooth and shining) (New Zealand) Moaxiphia Antennae farther apart, distance between antennal sockets more than twice as long as distance from antennal socket to front of clypeus (as in Figs 22, 62, 100); antenna usually not more than 21-segmented; genal carina present 9

9. Head sculptured, gena and vertex dull with dense surface microsculpture or cross striations; occipital carina very narrow, much less than one-third diameter of an ocellus (hind wing with full complement of cells, as in Fig. 69) Rhysacephala Head with genae and vertex smooth and shining; occipital carina narrow or well developed, to half or more diameter of an ocellus 
10. Antennal pedicel 1.5X or less longer than broad (Fig. 19); hind wing with cells Rs and M absent, anal cell usually absent (Fig. 18); thorax with mesopleuron and sometimes mesoscutum and/or mesoscutellum smooth and shining; vertex with medial longitudinal shallow furrow or row of punctures Lissoxiphyda (in part) Antennal pedicel 2X or more longer than broad; hind wing with cells Rs and $\mathrm{M}$ and anal cell present; thorax usually heavily sculptured, without smooth, shiny areas; vertex without median furrow or row of punctures Calexiphyda

11. Maxillary palpus 7-segmented, nearly twice length of labial palpus 12 [Lissoxiphyda may key here, but the male is unknown; they are probably rather small, shiny, and black, without cells Rs, M, and A in the hind wing, and with the antennal pedicel about as long as broad, similar to the female]

Maxillary palpus 4- or 5-segmented, about half length of labial palpus 14

12. Antennae close together, distance between antennal sockets much less than twice distance between antennal sockets and front of clypeus; antenna long, 25-segmented; genal carina absent (gena and vertex smooth and shining) (New Zealand) Moaxiphia Antennae farther apart, distance between antennal sockets more than twice as long as distance from antennal socket to front of clypeus (as in Figs 22, 62, 100); antenna not usually more than 21-segmented; genal carina present 13

13. Head sculptured, gena and vertex dull with dense surface microsculpture or cross striations; occipital carina very narrow, much less than diameter of an ocellus; vertex with medial longitudinal shallow furrow or row of punctures Rhysacephala Head with genae and vertex smooth an shining; occipital carina well developed, half or more diameter of an ocellus and expanded laterally; vertex without shallow furrow or row of punctures Calexiphyda

14. Antennal flagellum swollen at base, tapering to acute apex (Figs 82, 87);pronotum rounded in dorsal view (Figs 84, 89); tarsal claws with inner tooth subequal in length to outer tooth and closely appressed to it (Fig. 119) (cells Rs and M and anal cell of hind wing usually absent, Fig. 91) Obesaxiphyda

Antenna filiform; pronotum deeply concave laterally in dorsal view (Fig. 46); inner tooth of tarsal claws usually situated near center of claw (Fig. 104) 15

15. Forewing costal cell broad (Figs 110, 120); anal cell of hind wing rounded at apex (Figs 110, 121) Lataxiphyda

Forewing costal cell narrow (Fig. 69); anal cell of hind wing flattened at apex (Fig. 69)....

16. Frons with longitudinal carinae; genal carina absent, genae with several longitudinal carinae especially on lower half Indoxiphia Frons reticulate, without distinct longitudinal carinae; genal carina distinct Hyperxiphia

[Distinction between the males of Hyperxiphia and Indoxiphia is based only on associated males of two species; characters in this couplet may change.] 


\section{Lissoxiphyda SMITH, new genus}

Type species: Xiphidria (!) rufipes F. Sмітн.

\section{Description:}

Antenna filiform, 17-21 segmented; pedicel 1.5X longer than broad or slightly less (Fig. 19); eyes small, oval, lower interocular distance greater than eye height, inner margins subparallel; head in lateral view short behind eyes (Figs 1, 2, 6, 9, 14, 15, 19, 22), in dorsal view, sharply narrowing behind eyes (Fig. 13); malar space almost linear; genal carina present, sometimes indistinct, usually extending to top of eye; occipital carina very narrow, of equal width laterally and dorsally; shallow median longitudinal furrow or row of punctures present on vertex; labial palpus 4-segmented; maxillary palpus 7-segmented, $2 \mathrm{X}$ or more longer than labial palpus; gena and vertex smooth, shining; frons usually with fine reticulate sculpture. Pronotum distinctly concave laterally (Fig. 4); mesonotum commonly with shining unsculptured parts (mesoscutal lateral lobes and or mesoscutellum may be unsculptured); mesepisternum usually smooth, shining, without significant sculpture. Tarsal claws each with an inner tooth (absent on hind claw of L. tripotini). Forewing: Costal cell narrow, less than $2 \mathrm{X}$ width of costa. Hind wing: Cells Rs, M, and A absent (Fig. 18) (cell A present in L. tripotini, Fig. 28). Male unknown.

Etymology: From lisso, Greek for smooth, combined with -xiphyda, from Xiphydriidae. Gender: feminine.

\section{Remarks:}

The seven included species form a group of small $(5.5-10 \mathrm{~mm})$, shining, and mostly black species with long maxillary palpi, each tarsal claw with an inner tooth, lack of enclosed cells in the hind wing, and presence of a shallow median longitudinal furrow on the vertex. The long, 7-segmented maxillary palpus relates them to Moaxiphia of New Zealand, Calexiphyda from New Caledonia, and Rhysacephala of Australia. All three genera have the full complement of cells in the hind wing, whereas Lissoxiphyda lacks cells M, Rs, and usually A. They share with Rhysacephala and Calexiphyda the long distance between the antennae which is longer than the antenno-ocular distance; however, Rhysacephala has a dull, sculptured gena and vertex which are entirely shining in species of Lissoxiphyda, and Calexiphyda has a broad occipital carina which is enlarged laterally and lacks a median furrow or row of punctures on the vertex. Moaxiphia has the vertex smooth and shining, the distance between the antennal insertions about equal to the antenno-ocular distance, and long, 24-segmented antenna. The presence of a shallow longitudinal median furrow or row of punctures on the vertex is shared with Rhysacephala. Males are unknown for this genus but probably can be associated by the 7 -segmented maxillary palpus, smooth and shining appearance, and lack of cells in the hind wing.

I have included L. tripotini from New Caledonia in this genus. Though it differs from other species by the simple hind claws, presence of cell $\mathrm{A}$ in the hind wing, and longer scape, it shares with them the shiny appearance, especially the mesopleuron, longitudinal furrow on the vertex, lack of cell Rs and $\mathrm{M}$ in the hind wing, and small occipital carina.

This genus is distributed in a rather small area, from Papua New Guinea to Aru and Sulawesi in Indonesia, and one species in New Caledonia. 
Key to Species (Females)

1. Legs black with basitarsi and basal quarter of middle and hind tibiae white (Fig. 22) ... 2

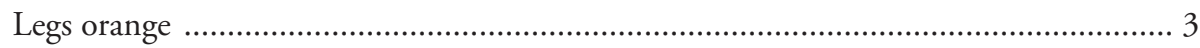

2. Lateral yellow spots on abdominal tergite 8; mesoscutellum smooth with few widely scattered punctures mostly on anterior half (Fig. 26); mesoscutal lateral lobes mostly smooth, with punctures on inner margins (Fig. 26); frons with smooth, non-sculptured area below ocelli (Fig. 23) simbai, n. sp.

- Lateral yellow spots on abdominal tergites 6-8; mesoscutellum reticulate, only lateral and hind margins smooth (Fig. 5); mesoscutal lateral lobes smooth, reticulate anteriorly and on inner margins (Fig. 4); frons entirely reticulate (Fig. 2) kiunga, n. sp.

3 Mesoscutellum sculptured, with radiating diagonal striae on anterior half (Fig. 21) or densely punctate (Fig. 30) 4

- $\quad$ Mesoscutellum shining, without sculpture or with a few punctures anteriorly (Figs 7, 10, 16); abdomen black or with lateral yellow spots on tergites 5-8 5

4. Mesoscutellum with radiating diagonal striae on anterior half (Fig. 21); abdomen with lateral yellow spot on tergite 8 shinoharai, n. sp.

Mesoscutellum densely punctate (Fig. 30); tergites 4-8 with lateral white spots and small spot on $9^{\text {th }}$ tergite tripotini, n. sp.

5. Abdomen black, without lateral yellow spots; mesoscutum with fine, almost transverse sculpturation (Figs 7, 10); mesepisternum smooth and shining (Figs 8, 11)

Abdomen with lateral yellow spots on tergites 5-8; mesoscutum with dense, distinct reticulate sculpturation (Fig. 16); mesepisternum dulled with microsculpture, with a few large punctures at center (Fig. 17) rufipes (F. SMITH)

6. Frons mostly striate, without curved carinae above antennal insertions (Fig. 6); mesoscutal middle lobe finely transversely striate (Fig. 7); mesosternum orange ........... lucida, n. sp.

- $\quad$ Frons mostly reticulate, with arclike curved carinae above antennal insertions (Fig. 9); mesoscutal middle lobe coarsely reticulate to transversely striate (Fig. 10); thorax black .. morobe, n. sp.

\section{Lissoxiphyda kiunga SMITH, new species}

(Figs 1-5)

\section{Diagnosis:}

Legs black with basitarsi and basal quarter of middle and hind tibiae white; mesoscutellum densely reticulate; lateral white marks on abdominal tergites 6-8; frons sculptured up to level of lateral ocelli; mesoscutal lateral lobes smooth with fine striae on inner margins.

\section{Female:}

Length, $6.5 \mathrm{~mm}$. Color: Black with basitarsi and basal quarter of middle and hind tibiae white and lateral yellow spots on abdominal tergites 6-8. Head: Antennal length 1.7X head width; 
17-18 segmented; scape:pedicel: $1^{\text {st }}$ antennomere as 1.0:0.4:0.9; pedicel 1.3X longer than broad. Malar space short to linear, malar depression shallow. Genal carina short, apparently present on lower third of gena. Lower interocular distance subequal to eye height; inner margins of eyes almost straight (Fig. 2). Labial palpus apparently 4-segmented. Maxillary palpus hidden. Frons shining, interocellar area, frons, and interantennal area finely reticulate, somewhat dull with microsculpture at center (Fig. 2); gena and vertex smooth, shining, few fine punctures on hind orbits. Thorax: Mesoscutal middle lobe reticulate, with irregular transverse carinae; lateral lobes shining, reticulate on inner margins (Fig. 4). Axilla mostly smooth, without sculpture (Fig. 5). Mesoscutellum entirely densely reticulate (Fig. 5). Propleuron smooth, without sculpture (Fig. 3). Pronotum punctured on lateral corners, shining, practically without sculpture laterally (Fig. 3). Mesepisternum mostly smooth, shining, some, few punctures anterodorsally; mesepimeron scrobiculate on posterior margin (Fig. 3); metapleuron shining, reticulate dorsally (Fig. 3). Wings as for genus; unable to see anal cell of hind wing. Foreclaw with small inner tooth at center, shorter than half length of outer tooth; hind claw with small inner tooth near base, shorter than half length of outer tooth, with large circular notch between inner and outer teeth. Hind basitarsus $0.8 \mathrm{X}$ length of remaining tarsal segments. Abdomen: Shining but with fine microsculpture, microsculpture denser on anterior halves of tergites 1-4. Length of basal plates subequal to length of $2^{\text {nd }}$ tergite. Sheath and valvifer 2 subequal in length (Fig. 1). Lengths of sheath:valvifer 2:hind tibia as 0.8:0.7:1.0.

Male: Unknown.

Holotype: Female, labeled “New Guinea: Papua, Kiunga, Fly River, VII-4-8-1957,” “W.W. Brandt, Collector" (BPBM).

Etymology: The name is from the type locality, a noun in apposition.

\section{Remarks:}

This and L. tripotini are the only species of Lissoxiphyda that have a densely sculptured mesoscutellum (Fig. 5). In L. kiunga, only the axillae and lateral parts of the mesoprescutal lateral lobes are smooth and shining, and cell $\mathrm{A}$ is absent in the hind wing. It is separated from L. simbai, the only other species with mostly black legs by the densely sculptured mesoscutellum and frons (Fig. 2).

\section{Lissoxiphyda lucida SMITH, new species}

(Figs 6-8)

\section{Diagnosis:}

Legs orange; mesosternum orange; abdomen black; mesonotum almost entirely smooth, shining, with fine transverse striae on posterior two-thirds of mesoscutal middle lobe; mesoscutellum and axilla smooth, shining.

\section{Female:}

Length, $6.5 \mathrm{~mm}$. Color: Black; scape, pedicel and mesosternum dark orange. Legs yellow with apical tarsal segments black. Wings hyaline, veins and stigma black. Head: Antenna broken beyond $6^{\text {th }}$ segment on right antenna; scape:pedicel: $1^{\text {st }}$ antennomere as 1.0:0.5:1.0; pedicel $1.4 \mathrm{X}$ longer than broad. Malar space narrow; malar depression shallow. Genal carina indistinct, not discernable. Lower interocular distance $1.2 \mathrm{X}$ eye height; inner margins of eyes almost parallel 
(Fig. 6). Labial palpus 4-segmented, apical segment slightly clubbed. Maxillary palpus with $2^{\text {nd }}$ segment about as long as following 4 segments, apical 5 segments about equal in length. Frons shining, smooth without sculpture anterior to front ocellus; mostly finely reticulate at center and curved, irregular longitudinal carinae ending at interantennal area (Fig. 6); vertex and gena smooth, shining, without sculpture. Thorax: Mesoscutal middle lobe smooth and shining on anterior third, posterior third finely reticulate, with irregular transverse sculpture; mesoscutal lateral lobes smooth and shining, reticulate on inner margins (Fig. 7). Axilla and mesoscutellum smooth and shining (Fig. 7). Propleuron shining, smooth, without distinct sculpture. Pronotum smooth and shining laterally, finely reticulate in dorsal margin (Fig. 8). Mesepisternum smooth and shining; mesepimeron finely scrobiculate (Fig. 8). Metapleuron smooth and shining, few indistinct punctures dorsoanteriorly. Hind wing apparently with cells Rs and M open (wings appressed to each other, difficult to see). All claws with inner tooth located at center of claw, inner tooth of foreclaw about half length of outer tooth, inner teeth of middle and hind claws slightly longer than half length of outer teeth, middle and hind claws larger than foreclaw. Hind basitarsus $0.7 \mathrm{X}$ length of remaining tarsal segments combined. Abdomen: Smooth, shining, with very fine microsculpture. Length of basal plates subequal to length of $2^{\text {nd }}$ tergite. Apical segment unusually long, length greater than length of hind tibia and hind tarsus together. Lengths of sheath:valvifer 2:hind tibia as 0.9:1.1:1.0.

Male: Unknown.

Holotype: Female, labeled "New Guinea: NE, Wau, 1190 m, 15.IX.1964,” “J. Sedlacek, Malaise Trap, Bishop" (BPBM).

Etymology: From the Latin adjective lucidus, shining, referring to the smooth, shining axillae, mesoscutellum, and mesopleuron.

\section{Remarks:}

This is the only species of Lissoxiphyda I have seen with an orange mesosternum. Otherwise, it is similar to L. morobe and L. rufipes by the smooth and shining axillae and mesoscutellum (Fig. 7) and orange legs. It is most similar to L. morobe, sharing the finely sculptured mesoscutum, frons, and mesepisternum which are densely sculptured in L. rufipes (Figs 14, 16, 17). The less evident circular carinae above the antennal insertions (Fig. 6), more finely sculptured mesoscutum (Fig. 7), and lack of large punctures on the dorsum of the mesepisternum (Fig. 8) will separate L. lucida from L. merobe.

\section{Lissoxiphyda morobe SMITH, new species}

(Figs 9-11)

\section{Diagnosis:}

Legs orange; abdomen black; mesoscutal middle lobe and inner margins of lateral lobes finely transversely striate; mesoscutellum smooth, shining.

\section{Female:}

Length, $10.0 \mathrm{~mm}$. Color: Black; coxae and femora orange, tibiae orange with base of hind tibia white; hind basitarsus white, rest of hind tarsus black. Head: Antenna broken; scape:pedicel: $1^{\text {st }}$ antennomere as 1.0:0.5:1.0; pedicel 1.3X longer than broad. Malar space distinct, narrow. Genal carina faint on lower quarter of gena. Lower interocular distance 1.2X eye height; eyes 
slightly diverging below (Fig. 9). Labial palpus 4-segmented, apical segment enlarged, clubbed. Maxillary palpus apparently 7 -segmented, separation of $5^{\text {th }}$ and $6^{\text {th }}$ segments faint, possibly equal one segment; $2^{\text {nd }}$ segment nearly equal to length of following 3 segments, segments 3-6 about equal in length. Frons sculptured, except area just below front ocellus; mostly reticulate with arclike carinae from interantennal area to above antennal insertions (Fig. 9). Gena and vertex smooth and shining. Thorax: Mesoscutal middle lobe smooth, shining on anterior quarter, rest finely reticulate, irregularly transversely striate; lateral lobes smooth and shining, finely striate to reticulate on inner margins (Fig. 10). Axilla and mesoscutellum smooth and shining (Fig. 10). Propleuron smooth and shining. Pronotum smooth and shining with few curved carinae dorsally (Fig. 11). Mesopleuron smooth, mostly shining, dull with microsculpture and few large punctures dorsally (Fig. 11). Mesepimeron smooth and shining (Fig. 11). Metapleuron shining with few irregular punctures (Fig. 11). Foreclaw with small inner tooth less than half length of outer tooth, midclaw missing, hind claw with long, curved outer tooth and minute inner tooth near base, with large circular notch between inner and outer teeth; hind claw much larger than foreclaw. Hind basitarsus $0.6 \mathrm{X}$ length of remaining tarsal segments combined. Abdomen: Shining but with fine microsculpture. Length of basal plates subequal to length of $2^{\text {nd }}$ tergite. Lengths of sheath:valvifer 2:hind tibia as 0.7:0.8:1.0.

Male: Unknown.

Holotype: Female, labeled "New Guinea: (NE) Wau, Morobe Distr., 1000 m, 13.X.1961," "J. Sedlacek, Malaise Trap, Bishop" (BPBM).

Etymology: The name is from the type locality, a noun in apposition.

\section{Remarks:}

This species is similar to L. lucida except for the black thorax and sculpturation features as discussed under that species.

\section{Lissoxiphyda rufipes (F. SMITH), new combination}

(Figs 12-17)

Xiphidria (!) rufipes F. Smith 1859: 177.-Westwood 1974: 112.-Dalla Torre 1894: 397.-Konow 1897: 301, 303, 310.-Konow 1905a: 4.-Konow 1905b: 42, 44.-Hedicke 1938: 12.

Moaxiphia rufipes: MAA 1949: 29.

Rhysacephala rufipes: Benson 1954: 159, 160.-SMITH 1978: 111.-JENnINGs et al. 2007: 23.

\section{Diagnosis:}

Legs orange; lateral yellow spots on abdominal tergites 5-8; thorax dulled with microsculpture but mesoscutum densely, distinctly reticulate and axilla, mesoscutellum, and mesosternum shining; frons entirely reticulate up to lateral ocelli.

\section{Female:}

Length, $10.5 \mathrm{~mm}$. Color: Black with legs orange and abdominal tergites 5-8 with small lateral yellow spots. Wings hyaline. Head: Antenna filiform, 21-segmented; length about 1.6X head width; scape:pedicel: $1^{\text {st }}$ antennomere as 1.0:0.4:1.1; pedicel 1.2X longer than broad. Malar space linear. Genal carina indistinct, but extends to top of eye. Lower interocular distance 1.2X eye height; inner margins of eyes almost parallel (Fig. 14). Palpi difficult to see, but labial palpus apparently 4-segmented and maxillary palpus 7-segmented. Frons and interantennal area densely, 
finely reticulate, up to and slightly behind lateral ocelli (Fig. 14). Gena and vertex smooth, shining, with few scattered small punctures (Fig. 15). Thorax: Mesoscutum entirely reticulate (Fig. 16). Axilla and mesoscutellum shining, with scattered punctures, denser on anterior half of mesoscutellum, mostly separated by interspaces longer than diameter of punctures (Fig. 16). Propleuron irregularly reticulate. Lateral pronotum reticulate with large shining area on lower half (Fig. 17). Mesepisternum mostly smooth and shining, somewhat duller with microsculpture and with few large adjacent punctures on upper half; mesepimeron scrobiculate on posterior margin (Fig. 16) Metapleuron smooth, shining, with few irregular punctures on upper half Fig. 17). All tarsal claw bifid. Hind basitarsus $0.7 \mathrm{X}$ length of remaining tarsal segments combined. Abdomen: Smooth and mostly shining with basal plates dull anterolaterally, shining anteromedially and posteriorly; tergites subshining duller with fine microsculpture on anterior margins. Length of basal plates slightly longer than length of $2^{\text {nd }}$ tergite, as 1.0:0.8. Sheath:valvifer 2:hind tibia as 0.6:0.7:1.0.

Male: Unknown.

Type: The female syntype is at OUMNH, with the following labels "Aru" (white, round); a blank white round label; "TYPE, O.U.M." (round, white with red border), "Xiphidria rufipes Smith" (handwritten), and "Oxford University Museum of Natural History (OUMNH)." Westwood (1859) described the female from "Aru." The number of specimens was not indicated; thus, I am designating this specimen a lectotype to ensure nomenclatural stability.

\section{Remarks:}

Lissoxiphyda rufipes has orange legs, similar to L. lucida, L. morobe, L. shinoharai, and L. tripotini, but has lateral yellow spots on tergites 5-8. In L. lucida and L. morobe, the abdomen is black, in L. shinoharai, the abdomen has a lateral yellow spot only on tergite 8 , and in L. tripotini the abdomen has lateral yellow spots on tergites 4-8. The sculpturation of the mesoscutum, mesepisternum, and frons (Figs 14, 16, 17) is also much denser and more evident than that of the other species.

\section{Lissoxiphyda shinoharai SмIтH, new species}

(Figs 18-21)

\section{Diagnosis:}

Legs orange; lateral yellow spot on tergite 8; mesoscutal middle lobe and inner margins of mesoscutal lateral lobes reticulate; mesoscutellum with fan-shaped striae radiating from anterior margin.

\section{Female:}

Length, $9.0 \mathrm{~mm}$. Color: Antenna, head, and thorax black; legs mostly yellow orange; coxae, femora, apical tarsal segments darker. Abdomen black with yellow spot laterally on $8^{\text {th }}$ tergite. Head: Antenna filiform, 21-segmented; length $2 \mathrm{X}$ head width; scape:pedicel: $1^{\text {st }}$ antennomere as 1.0:0.3:0.9; pedicel 1.3X longer than broad (Fig. 19). Malar space narrow. Genal carina faint, extending to top of eye. Lower interocular distance 1.2X eye height; inner margins of eyes almost parallel (Fig. 19). Labial palpus 4-segmented. Maxillary palpus 7-segmented. Frons and interantennal area mostly finely reticulate, mostly reduced to microsculpture just below ocelli; one or two arclike carinae from interantennal area to above antennal insertions (Fig. 19). Vertex and gena smooth, shining. Thorax: Mesoscutal middle lobe mostly reticulate, with irregular short 
transverse carinae on posterior two-thirds; lateral lobes smooth and shining, reticulate at anterior and on inner margins (Fig. 21). Axilla smooth and shining with few irregular punctures (Fig. 21). Mesoscutellum shining with fine striae radiating posteriorly from anterocentral margin (Fig. 21). Propleuron smooth, shining. Pronotum smooth shining, reticulate on upper third (Fig. 20). Mesepisternum smooth and shining, with fine microsculpture and few punctures at center and anterior portion; mesepimeron scrobiculate (Fig. 20). Metapleuron reticulate (Fig. 20). Tarsal claws with inner tooth about half length of outer tooth and locate at center of claws; hind claw larger than fore- and midclaws. Hind basitarsus $0.8 \mathrm{X}$ length of remaining tarsal segments combined. Abdomen: Basal plates finely sculptured anterolaterally, smooth and shining on inner and posterior margins; rest of abdomen shining with fine microsculpture. Length of basal plates 1.3X length of $2^{\text {nd }}$ tergite. Sheath:valvifer 2:hind tibia as 1.0:1.4:1.8.

Male: Unknown.

Holotype: Female, labeled "Indonesia, 50 km S.of Menado, 1200 m, 2-10 Dec. 1973, H. Kurahashi" (NSMT). Menado is on the northern end of the northern peninsula of Sulawesi.

Etymology: Named for Dr. Akihiko Shinohara, National Museum of Science and Nature, Tokyo, Japan, who brought this specimen to my attention.

\section{Remarks:}

Two features separate this species from other species of Lissixiphyda, the presence of the fan-shaped radiating striae from the anterior portion of the mesoscutellum and the presences of a lateral yellow spot only on abdominal tergite 8 . Other species lack the radiating striae on the mesoscutellum and have a black abdomen or, in L. rufipes, lateral yellow spots on tergites 5-8.

\section{Lissoxiphyda simbai SMITH, new species}

(Figs 22-26)

\section{Diagnosis:}

Legs black with basitarsi and basal quarter of middle and hind tibiae white; lateral yellow spot on tergite 8; frons with smooth, non-sculptured area below ocelli; anterior half of mesoscutal middle lobe smooth; mesoscutal lateral lobes smooth, punctured on inner margins; mesoscutellum smooth and shining with few widely-spaced punctures.

Female:

Length, $5.5 \mathrm{~mm}$. Color: Black; antennal segments 1 and 2 dark brown, small white spot laterally on abdominal segment 8 and two yellow spots on dorsum of $9^{\text {th }}$ tergite; dorsal margin of sheath brown. Foreleg pale brown; midleg and hind leg with trochanters, basal 1/3 of tibiae, and all basitarsi white. Head: Antenna filiform, 18-segmented; length 2.0X head width; scape:pedicel: $1^{\text {st }}$ antennal segment as 1,0:0.4:0.8; pedicel 1.3X longer than broad. Malar space distinct, narrow. Genal carina not discernable. Lower interocular distance $1.3 \mathrm{X}$ eye height; inner margins of eyes almost parallel (Fig. 23). Labial palpus 4-segmented; maxillary palpus 7-segmented. Frons smooth and shining below ocelli, rest of frons and interantennal area shining and finely punctate to reticulate (Fig. 23). Gena and vertex smooth and shining. Thorax: Mesoprescutal middle lobe smooth and shining on anterior fifth, rest reticulate, with median row of punctures; lateral lobes smooth and shining, finely reticulate on inner margins (Fig. 26). Axilla and mesoscutellum smooth and shining, with very few widely spaces small punctures (Fig. 26). Propleuron smooth and shining. 
Pronotum mostly shining with few striae and reticulations on posterior and dorsal areas (Fig. 25). Mesepisternum smooth, shining, with fine microsculpture; mesepimeron scrobiculate (Fig. 25). Metapleuron shining, finely reticulate (Fig. 25). Each tarsal claw with inner tooth, foreclaw with small inner tooth near base, shorter than half length of long, curved outer tooth, middle and hind claws with moderate tooth at center less than half length of outer tooth, larger than inner tooth of foreclaw, middle and hind claws larger than foreclaw. Hind basitarsus $0.7 \mathrm{X}$ length of remaining tarsal segments combined. Abdomen: Shining with fine microsculpture. Length of basal plates subequal to length of 2 nd tergite. Sheath:valvifer 2:hind tibia as 7.0:9.0:1.0.

Male: Unknown.

Holotype: Female, labeled "Baiyer R. - Jimmi V., 1800 m, New Guinea, XII.27.78-I.26.79, J. Sedlacek" (AEIC). Paratypes: "New Guinea: NE, Simbai, 1600-1800 m, X-1968," "N. L. H. Krauss, Bishop Museum" ["Malaise Trap" crossed out on label] (1 9 , BPBM); "NE New Guinea: Umboi I, 1 km N Awelkom, 600 m, 21-28.II.1967,” “G. A. Samuelson, Light Trap, Bishop" (1 9 , BPBM) (the abdomen is missing).

Etymology: The name is from the locality of one of the paratypes, a noun in apposition.

\section{Remarks:}

The paratypes are very similar to the holotype but with slightly less distinct sculpturation on the frons.

See notes under L. kiunga, the only other species with mostly black legs, for separation of the two species. The frons of $L$. simbai is much smoother and more shining than in other species of Lissoxiphyda.

\section{Lissoxiphyda tripotini SMITH, new species}

(Figs 27-30)

\section{Diagnosis:}

Hind wing with cell A present. Hind claw simple. Pedicel 1.7X longer than broad. Mesonotum and head dull, punctate; mesopleuron shining.

\section{Female:}

Length, $7.0 \mathrm{~mm}$. Color: Black to dark brown; scape, pedicel, base of mandible, and palpi yellow brown, apex of mandible black. Thorax black with upper mesepisternum, lower propleuron, and mesonotum tending to dark red brown. Legs yellowish with coxae and apical tarsal segments darker brownish. Abdomen black, tergites 4-8 with lateral white spots, $9^{\text {th }}$ tergite with two yellow spots at base; basal plates yellow, sheath with valvifer 1 yellow, apically black with yellow spot on upper center. Head: Antenna18-segmented; length 2.0X head width; scape: pedicel: $1^{\text {st }}$ antennomere as 1.0:0.4:0.8; pedicel about 1.7X longer than broad. Malar space linear. Genal carina and occipital carina distinct. Lower interocular distance subequal to eye height (Fig. 27). Labial palpus 4-segmented, apical segment clubbed; maxillary palpus slender but longer than labial palpus, 7-segmented. Frons finely sculptured, somewhat reticulate at center and more punctate laterally (Fig. 27). Gena and vertex shining with very few widely scattered punctures. Thorax: Mesoscutal middle lobe evenly reticulate; lateral lobes similarly reticulate (Fig. 30). Axilla and mesoscutellum reticulate similar to mesoscutum except apex of mesoscutellum smooth, shining (Fig. 30). Metanotum smooth, shining. Propleuron 
smooth, shining. Pronotum shining, finely reticulated posterodorsally and ventrally (Fig. 29). Mesepisternum shining with very few large, widely spaced punctures at center; mesepimeron shining, reticulate (Fig. 29). Metapleuron shining, reticulate. Hind wing with cells Rs and $\mathrm{M}$ absent; anal cell present (Fig. 28). All tarsal claws simple; hind claw larger than fore- and midclaws and with slight basal lobe. Hind basitarsus $0.7 \mathrm{X}$ length of remaining tarsal segments combined. Abdomen: Mostly shining except anterolateral portion of basal plates and anterior margin of segments 2-8 dull and microsculptured. Length of basal 1.2X length of second tergite. Sheath:valvifer 2: hind tibia as 0.7:1.0:0.9.

Male: Unknown.

Holotype: Female, labeled "N. Caledonia, Prov. Sud Sarraméa forêt de col d'Amieu / 2 Malaise tr. in openings around sawmill, 31 XII $~ 2$ I 06, P. Tripotin rec." (MNHN).

Etymology: Named for Pierre Tripotin, Okcheon-gun, South Korea, who collected this species and brought it to my attention.

\section{Remarks:}

The three characteristics mentioned in the diagnosis separate this species from other species of Lissoxiphyda. Its similar habitus, shiny appearance, especially the mesopleuron, presence of a longitudinal furrow on the vertex, small occipital carina, and absence of cells Rs and $\mathrm{M}$ in the hind wing are shared with other species in the genus.

\section{Calexiphyda SMITH, new genus}

Type species: Calexiphyda blanki, n. sp.

\section{Description:}

Antenna filiform, 17-23 segmented; pedicel $2 \mathrm{X}$ or more longer than broad; eyes large, lower interocular distance about equal to eye height, inner margins of eyes usually diverging below, head short behind eyes in lateral view (Figs 31, 34, 39), in dorsal view, sharply narrowing behind eyes; malar space short, almost linear; genal carina distinct, extending to tip of eye; occipital carina broad, about equal half diameter of an ocellus, lateral portions expanded and broader than dorsal portion (Fig. 35); labial palpus 4-segmented; maxillary palpus 7-segmented, more than 2X length of labial palpus; gena and vertex smooth and shining; frons reticulate or finely punctured. Pronotum deeply excavated laterally (Fig. 37); mesonotum densely sculptured (except C. crocea relatively smooth). Tarsal claws each with an inner tooth. Forewing: Costal cell narrow, less than $2 \mathrm{X}$ broader than costa. Hind wing: Cells Rs, M, and A present; anal cell with vein $1 \mathrm{~A}$ straight, vein $2 \mathrm{~A}$ sharply upturned at apex and meeting $1 \mathrm{~A}$ to form cell.

Etymology: The name is from the first syllables of Caledonia, with the suffix -xiphyda, from Xiphydriidae. Gender: feminine.

\section{Remarks:}

The long, 7-segmented maxillary palpus is shared with Rhysacephala, Moaxiphia, and Lissoxiphyda. Calexiphyda is differentiated from Moaxiphia by the long interantennal area and distinct genal carina. From Rhysacelphala, Calexiphyda is separated by the smooth, shining gena and vertex, well-developed, wide occipital carina which is broadened laterally, absence of a longitudinal median furrow on the vertex, and the distinct genal carina which reaches to the top of the eye. 
From Lissoxiphyda, Calexiphyda is distinguished by the long pedicel, genal carina reaching top of the eye, broadened occipital carina laterally, absence of the median furrow on the vertex, and having the full complement of cells in the hind wing.

Several unassociated males are known that may be males of the two described females or represent distinct species. Additional collecting and rearing are needed to help clarify their identity.

This genus is known only from New Caledonia.

\section{Key to Species}

1. Male; orange; head and thorax largely smooth and shining, without coarse sculpturation (Figs 39-41) (though the female is unknown, it should be easily associated because of the lack of sculpture) croceus, n. sp.

- $\quad$ Female; entirely black or black with yellow markings on head and thorax (Figs 34, 36, 37); coarse sculpturation on head and thorax (Figs 31-37)

2. Forewing hyaline with light black cross bands; yellow markings on head and pronotum (Figs 34, 36, 37); mesoscutal middle lobe with transverse sculpture (Fig. 37)

blanki, n. sp.

Forewing uniformly hyaline; head and pronotum black; mesoscutal middle lobe with longitudinal sculpture (Fig. 32) caledonia, n. sp.

\section{Calexiphyda caledonia SMITH, new species}

(Figs 31-33)

\section{Diagnosis:}

Entirely black with sheath and middle and hind tibiae and tarsi brownish orange. Mesonotum with longitudinal striae. Wings uniformly hyaline.

\section{Female:}

Length, $13.0 \mathrm{~mm}$. Color: Black, only sheath and middle and hind tibiae and tarsi brownish orange. Head: Antenna broken beyond 12th segment; scape:pedicel: $1^{\text {st }}$ antennomere as 1.0:0.4:0.8; pedicel 2.0X longer than broad. Malar space distinct, narrow, less than half diameter of an ocellus. Genal carina distinct to top of eye; occipital carina broad, equal to one-third diameter of an ocellus. Lower interocular distance 0.9X eye height; inner margins of eyes slightly diverging below (Fig. 31). Labial palpus 4-segmented. Maxillary palpus 7-segmented. Interocellar area and frons reticulate; several arc-shaped carinae from interantennal area over top of antennal insertions (Fig. 31). Gena and vertex smooth and shining, very few punctures immediately posterior to hind ocelli. Thorax: Mesoscutal middle lobe with longitudinal carinae and medial row of punctures; lateral lobes smooth and shining with oblique carinae on inner halves (Fig. 32). Axilla and mesoscutellum with oblique carinae (Fig. 32). Propleuron smooth and shining (Fig. 33). Pronotum mostly smooth and shining, few irregular reticulations dorsoposteriorly (Fig. 33). Mesepisternum reticulate; dorsoposterior margin and mesosternum smooth and shining; mesepimeron very finely striate (Fig. 33). Metapleuron irregularly striate (Fig. 33). Each tarsal claw with inner tooth half or more length of outer tooth; middle and hind claws larger than foreclaw. Hind basitarsus equal in length to remaining tarsal segments combined. Abdomen: Shining with fine microsculpture, sculpture 
densest on $1^{\text {st }}$ and $2^{\text {nd }}$ tergites. Length of basal plates subequal to length of $2^{\text {nd }}$ tergite. Sheath: valvifer 2:hind tibia as 0.8:0.9:1.0.

Male: Unknown.

Types: Holotype: Female labeled "New Caledonia, Riviere Bleue Prov. Pk., trail to Upper Riv. Bleue, 5-16 Nov. 1992, 290 m., D.W. Webb," "Malaise trap across forest path.” (DEI). Paratypes: Same data as for holotype (1 9 , DEI); New Caledonia, Prov. Sud, Mt. Khogis, 17 km NNE Nouméa, Malaise across path in rainforest, el. 425 m, 27/28 January 1996, MEIRWIN, DWWEBB, EISCHLINGER, 2210' 34"S, 166³0'17"E (1 우 UCDC).

Etymology: Named for the type locality, a noun in apposition.

\section{Remarks:}

This species is black with only the sheath and middle and hind tibiae and tarsi reddish brown. This plus the longitudinal carinae on the mesonotum are not known in other species of Calexiphyda or other xiphydriids in the region under study.

\section{Calexiphyda blanki SмIтн, new species}

(Figs 34-38)

\section{Diagnosis:}

Black; wings hyaline with light black crossbands. Head with yellow stripes on inner orbits, gena, and vertex; posterior margin of pronotum yellow. Mesoscutal middle lobe transversely sculptured.

\section{Female:}

Length, $18.5 \mathrm{~mm}$. Color: Antenna black, scape reddish brown. Head black with continuous yellow stripe from upper inner orbits, through malar area and gena to vertex and abruptly turning anteriorly to near lateral ocellus (Figs 34-36); 4 yellow spots, 2 lower frons dorsal to antennal insertions and 2 lateral to antennal insertions on interantennal area (Fig. 34). Thorax black with posterior margin and lateral angles of pronotum yellow and upper and posterior mesepisternum, mesosternum, mesepimeron, and metapleuron reddish brown (Figs 36, 37). Legs black with inner surfaces of tibiae reddish brown. Abdomen black with small lateral spots on tergites 2-6, and long lateral stripes on tergites 7 and 8 yellow. Wings hyaline, forewing with slightly darkened crossbands apical to stigma and halfway between stigma and base of wing. Head: Antenna 23-segmented; length 1.3X head width; scape:pedicel: $1^{\text {st }}$ antennomere as 1.0:0.4:0.8; pedicel 2.0X longer than broad. Malar space distinct, narrow. Genal carina distinct to top of eye. Lower interocular distance 1.1X eye height; inner margins of eyes slightly diverging below (Fig. 34). Labial palpus 4-segmented. Maxillary palpus 7-segmented. Interocellar area, frons, and interantennal area densely reticulate (Fig. 34). Gena and vertex smooth, shining, with few striae on outer orbits between eye and genal carina, scattered punctures on vertex, and reticulate area immediately posterior to hind ocelli. Thorax: Mesoscutal middle lobe smooth and shining on anterior quarter with few scattered punctures; posterior three-quarters finely transversely carinate with fine microsculpture; lateral lobes shining laterally, inner halves with arc-shaped oblique carinae (Fig. 37). Axilla shining with few punctures; mesoscutellum reticulate (Fig. 37). Propleuron shining, with fine punctures (Fig. 30). Pronotum deeply concave laterally; smooth, shining with oblique row of carinae at center (Figs 36, 37). Mesepisternum reticulate, depressed at 
center; posteroventral margin and mesosternum shining, with small acute angle at posteroventral edge of sculpturation; mesepimeron scrobiculate (Fig. 36). Metapleuron finely reticulate. Foreand midclaws each with long, slender inner tooth about half length or slightly more than half length of outer tooth; hind claw larger than fore- and midclaws, with outer tooth long and curved and with small inner tooth near base much shorter than half length of outer tooth (Fig. 38). Hind basitarsus equal to length of remaining tarsal segments combined. Abdomen: Shining, fine microsculpture on tergites 4-5 to apex. Length of basal plates subequal to length of 2 nd tergite. Sheath:valvifer 2:hind tibia as 0.8:1.0:0.7.

Male: Unknown.

Holotype: Female, labeled "New Caledonia, Foret di Thi, 29.X-1.XI.1967," "J. \& M. Sedlacek, Collector, Bishop” (BPBM).

Etymology: Named for the Dr. Stephan M. Blank, Deutsches Entomologisches Institut, who has been of considerable help in my work.

\section{Remarks:}

The yellow-marked head and pronotum (Figs 28, 30, 31), blackish crossbands of the forewing, and transverse sculpture of the mesoscutal middle lobe are not known in any other species of Calexiphyda.

\section{Calexiphyda crocea SMITH, new species}

(Figs 39-41)

\section{Diagnosis:}

Yellow with black mesoscutal lateral lobes. Head and thorax mostly smooth and shining.

Female: Unknown.

\section{Male:}

Length, $6.5 \mathrm{~mm}$. Color: Entirely yellow with blackish marks on postocellar area, and mesoscutal lateral lobes. Head: Antenna 17-segmented; length 2.0X head width; scape:pedicel: $1^{\text {st }}$ antennomere as 1.0:0.4:1.0; pedicel more than 2.0X longer than broad (Fig. 39). Malar space distinct, almost linear. Genal carina distinct to top of eye. Lower interocular distance 1.1X eye height; inner margins of eyes almost parallel (Fig. 39). Labial palpus 4-segmented. Maxillary palpus 7-segmented. Frons with fine reticulate sculpture, few large punctures near center (Fig. 39). Gena, ocellar area, and vertex smooth and shining. Thorax: Mesoscutal middle lobe smooth and shining with few, fine, irregular striae; lateral lobes smooth and shining with narrow band of fine striae on inner margins (Fig. 40). Axilla smooth and shining; mesoscutellum shining with fine, scattered punctures and irregular fine striae on sides (Fig. 40). Propleuron shining with few punctures (Fig. 41). Pronotum smooth and shining with several oblique carinae posterodorsally (Fig. 41). Mesepisternum smooth and shining; mesepimeron finely scrobiculate (Fig. 41). Metapleuron shining, finely punctured to reticulate (Fig. 41). Each tarsal claw with inner tooth about half or more length of outer tooth; each claw about same size. Hind basitarsus 1.1X length of remaining tarsal segments combined. Abdomen: Brightly shining; basal plates mostly smooth and shining, faintly punctate laterally. Length of basal plates $1.3 \mathrm{X}$ length of $2^{\text {nd }}$ tergite. 
Holotype: Male, labeled "New Caledonia: Prov. Sud Noumeá NNE $17 \mathrm{~km} \mathrm{Mt.} \mathrm{Koghis,}$ 29.11.-13.12.1998, 550 mm, Malaise, Mary \& Irwin, $22^{\circ} 10.567$ S, $166^{\circ} 30.293 E^{\prime \prime}$ (DEI).

Etymology: From the Latin adjective, croceus, yellow.

\section{Remarks:}

This is an unusual circumstance where I believe description and naming of an unassociated male is justified. This species is so structurally different from other members of the genus, particularly the smooth and shining head and thorax (Figs 33-35), that association with the female should not be difficult. It differs from $C$. novacaledonica by the smooth sculpturation.

\section{Unassociated Males}

\section{Calexiphyda novacaledonica JENNINGS and Austin, new combination}

Calexiphyda novacaledonica Jennings and Austin, in Jennings et. al. 2007: 25.

This was described from a single male, from "New Caledonia, 2214'S X 16650'E, Pic du Pin, site 2, $280 \mathrm{~m}, 26 \mathrm{Nov} 2004$, hand netting Burwell, Wright, rain forest" (MNHN). I have not been able to examine this specimen and can not confidently place it. From characters in the original description (Jennings et al. 2007), it apparently belongs in Calexiphyda, though nothing is mentioned about the lateral portion of the occipital carina. It is possible this is the male of C. caledonia, since the sculpturation on the frons and longitudinal sculpturation of the mesoscutal middle lobe and oblique sculpture of the inner half of the lateral lobes are somewhat similar. The yellow markings on the frons of $L$. novacaledonica may be only sexual differences. See Jennings et al. (2007) for illustrations.

\section{Unassociated Male \#2}

"New Caledonia, Col des Piroque, 14.II.1963," “C. M. Yoshimoto, Collector” (1, BPBM). Length $8.4 \mathrm{~mm}$. This specimen is very similar to $C$. caledonica except as follows: Antenna black, scape reddish brown. Head with ocellar area and frons to clypeus yellow, yellow extending through malar area to lower quarter of hind orbits; rest of gena and vertex dark brown. Thorax black with following yellow: spots on anterolateral corner of mesoscutal middle lobe, anterior corner of mesoscutal lateral lobe, and at center of mesoscutal lateral lobe adjacent to middle lobe; stripe from ventral to posterior margin of lateral pronotum. Mesepisternum light brown, more yellow dorsally and yellow spot at center of posterior margin. Legs black, femora light brown, coxae yellow. Abdomen black with reddish brown to yellowish anterior margins of segments and most of $8^{\text {th }}$ tergite; basal 2 or 3 sternites yellowish. Wings lightly infuscate, slightly more hyaline apically. Tarsal claws all of similar size. Abdomen shining; basal plates about $1.4 \mathrm{X}$ length of $2^{\text {nd }}$ tergite.

\section{Unassociated Male \#3}

"New Caledonia, Me Jejehari, 800 m, 165 34'30"E, 21 29'S, 5, Nov. 1986, R. L. Brown," "blacklight trap" (1, CNC). The sculpture is most similar to C. caledonia and C. novacaledonica, but it currently cannot be placed with any degree of certainty. The yellow marks on the face resemble those of $C$. novacaledonica, but they are not as distinct and somewhat differently shaped. Length, $5.0 \mathrm{~mm}$. Antenna black; basal 3-4 segments brownish. Head mostly brownish with lower 
frons, interantennal area, and stripe from lower inner orbits through malar area to lower outer orbits yellow. Thorax black with lateral pronotal angles yellow orange; mesosternum brownish. Legs entirely orange. Abdomen black; sternites yellow orange. All tarsal claws of similar size. Basal plates almost $2 \mathrm{X}$ longer than second tergite.

\section{Indoxiphia MAA}

Indoxiphia MaA 1949: 67. Type species: Xiphydriola quadricincta Benson. Original designation.-Benson 1954: 160.

Indoxiphia subg. Cingalixiphia MAA 1949: 67. Type species: Xiphydria striatifrons Cameron. Original designation. New synonymy.

Cingalixiphia: Benson 1954: 161.-Jennings et al. 2007: 25.

\section{Description:}

Antenna filiform, 13-18 segmented; pedicel usually $2 \mathrm{X}$ or more longer than broad; eyes large, lower interocular distance slightly less than to slightly greater than eye height, inner margins of eyes diverging below; head short behind eyes in lateral view (Figs 42, 43, 48, 51, 54, 59, 62, 66, 70,74 ), in dorsal view, short and narrowing behind eyes (Fig. 72); malar space linear to about half diameter of an ocellus; genal carina absent, replaced by 6 or more fine carinae or striae on gena (as in Fig. 43); occipital carina distinct, narrow, less than one-third diameter of an ocellus; labial palpus 3-4 segmented; maxillary palpus 4-5 segmented, very small, less than half diameter of labial palpus and less than half length of labial palpus; gena and vertex shining, smooth except for carina on gena; frons sculptured, usually with longitudinal carinae. Pronotum deeply excavated laterally; excavation of pronotal collar deep (Fig. 46). Mesonotum with dense sculpturing; mesepisternum shining or dulled with microsculpture, mostly with large punctures at center separated by narrow ridges or flat interspaces. Female with middle and hind or only hind tarsal claws simple (as in Fig. 57), hind tarsal claw larger than fore- and middle tarsal claws; male with inner tooth on each claw and all claws of equal size. Forewing; Costal cell narrow, less than $2 \mathrm{X}$ width of costa. Hind wing: Cells Rs, M, and A present (Rs absent only in specimen of I. sumatra); vein 1A straight, vein 2A abruptly upturned at apex meeting $1 \mathrm{~A}$ to form cell. Wings as in Fig. 69.

\section{Remarks:}

Available names for this group are Xiphydriola, Cingalixiphia, and Indoxiphia. Xiphydriola has all claws simple, $2 \mathrm{r}$ absent in the forewing, and cell Rs open in the hind wing. It includes only one species from far-eastern Russia (SMiтh 1978). Cingalixiphia and Indoxiphia were described as subgenera of Indoxiphia by MAA, but treated as genera by Benson (1954) who gave characters separating them. Both MAA and BENSON separated Indoxiphia by having only the hind tarsal claws simple and Cingalixiphia by having both middle and hind tarsal claws simple. However, examination of the holotype of I. quadricincta shows that it has both middle and hind tarsal claws simple, which corresponds to the original description by BENSON (1935), I. quadricincta has both middle and hind tarsal claws simple. Therefore, the primary character separating the two genera is invalid, and the two are considered synonymous here. I am treating all species with the hind tarsal claws simple and species with both the middle and tarsal hind claws simple as one genus, Indoxiphia. I choose Indoxiphia over Cingalixiphia because I have examined the type species of the latter. Benson (1954) used two other characters besides the tarsal claws. For Cingalixiphia, vein $A$ in the forewing is entire and the face is sculptured with longitudinal striae in front of the ocelli; for Indoxiphia, vein A in the forewing fades out before the anal crossvein and the face has coarse reticulate sculpture in front of the ocelli. Neither character warrants recognition of 
separate genera. Whether on not vein A fades out before reaching the anal crossvein is difficult to determine; there seems to be various degrees of "fading" and it is impossible to rely on this. All species treated here have more or less distinct longitudinal sculpturation on the frons. Some are very distinct, with shining interspaces, and there are various degrees of this to more or less reticulate but still with longitudinal striae or carinae.

Males are associated with only one species, I. falcata. Lissoxiphyda testacea (MocsáRY) was described from a male and is treated as an unassociated males at the end of the genus. Usual drastic color differences between the sexes occur in I. falcata. In addition, all tarsal claws of the males have an inner tooth, and all claws are of similar size; none are modified as in the females. This makes it very difficult to place species described from isolated males such as I. testacea. Indoxiphia testacea, however, is here placed in Indoxiphia because of the longitudinal carinae on the frons, lack of a genal carina, presence of several striae on the gena, and general sculpturation of the thorax such as the reticulate mesonotum and shining mesepisternum with large scattered punctures.

Nine species are here placed in Indoxiphia, excluding I. testacea. Of the nine species, two have only the hind tarsal claws simple and seven have both the middle and hind tarsal claws simple. This assemblage of species shares the following: Antennae short, usually around $1.5 \mathrm{X}$ head width and 13-18 segmented; antennal pedicel usually $2 \mathrm{X}$ or more longer than broad; absence of a distinct, prominent genal carina, being replaced on the lower half of the gena by 6 or more prominent striae; labial palpus 3 or 4-segmented, maxillary palpus 4 or 5 -segmented and always shorter than the labial palpus (when this can be determined); and the complete venation of the wings (except the hind wing of the specimen of I. sumatra).

Species of Indoxiphia occur in southeastern Asia, from India and southern China through Indonesia to Papua New Guinea and Fiji.

\section{Key to Species (Females)}

Indoxiphia testacea (Mocsáry) and the male of I. falcata, n. sp., are not included in the key. They are the only males known in the genus.

1. Thorax and abdomen orange to yellow orange; head orange or yellowish with black on vertex and frons 2

Thorax black, commonly with yellow or white stripes or spots on pronotum, mesonotum, and or pleurae; abdomen orange with black apex or black with white or yellow bands or lateral spots on tergites; head always black or marked with black ... 3

2. Only hind tarsal claws simple; head with black stripe posterior to ocelli between upper orbits and through ocellar area onto frons (Fig. 62); abdomen orange with apex black (Papua New Guinea) papuaensis, n. sp.

Middle and hind tarsal claws simple; head and abdomen uniformly orange (Papua New Guinea) falcata, n. sp.

3. Apical 10 flagellar segments white (middle and hind tarsal claws simple; base of tibiae, hind coxa, and hind basitarsus white; mesoscutellum black) (Indonesia: Ambon, Buru) laeviceps (F. SмIтH) 
4. Only hind tarsal claw simple; abdomen orange with tergites 7 and 8 and segment 9 black (Papua New Guinea) maai, n. sp.

- $\quad$ Both middle and hind tarsal claws simple; abdomen black with various white bands or lateral white spots 5

5. Mesonotum and metanotum black (Fiji) fijiensis, n. sp. Either mesoscutum, axilla, and/or mesoscutellum white or with white stripes or spots; metanotum white 6

6. Head with band of longitudinal striae between eyes posterior to ocelli (Fig. 42); mesoscutellum black (color pattern of mesonotum in Fig. 45) (Indonesia: Kalimantan) darlingi, n. sp.

- Head behind ocelli smooth, shining or reticulate immediately behind ocelli (Figs 66, 70, 72, 74); mesoscutellum white or partly white 7

7. Mesoscutellum yellowish white with broad medial black stripe (Fig. 71); frons mostly yellow, black only dorsally below ocelli (Fig. 70); frons with numerous, fine arclike carinae (Fig. 70); abdominal tergites 1 and 2 mostly yellow orange, tergites 3-6 with lateral yellow spots (Papua New Guinea) schiffi, n. sp.

- Mesoscutellum entirely yellowish to whitish or with small black medial spot at anterior (Figs 67, 76); frons mostly black except laterally (Figs 66, 74); frons with few, more widely separated and more or less straight longitudinal carinae (Figs 66, 75); bands and spots on abdominal tergites arranged differently 8

8. Pronotum mostly yellow (Figs 68); mesoscutal middle lobe with white stripes laterally; abdomen with yellow bands on tergites 2, 5, 6, and 9, and lateral yellow spots on tergites 3 and 4; mesepisternum somewhat shining with large punctures separated by flat interspaces half or more puncture diameters (Fig. 68) (Indonesia: Java) ........ quadricincta (Benson) Pronotum mostly black (Fig. 75); mesoscutal middle lobe black (Fig. 76); abdomen with yellow bands on tergites 1, 2, 5-7, and apex of 9; mesepisternum with large confluent punctures separated by narrow ridges much less than puncture diameters (Fig. 75) (Indonesia: Sumatra) sumatra, n. sp.

\section{Indoxiphia darlingi SMITH, new species}

(Figs 42-46)

\section{Diagnosis:}

Middle and hind claws simple. Narrow band of longitudinal striae between top of eyes behind ocelli. Mesoscutellum black; metanotum yellow. Abdomen with complete yellow bands on tergites 2 and $5-8$.

\section{Female:}

Length, $10.5 \mathrm{~mm}$. Color: Head yellow with black band on vertex behind ocelli extending to top of each eye and anteriorly through ocelli to above each antennal insertion and center of interantennal area; large yellow spot below front ocellus (Fig. 42). Thorax mostly black; pronotum yellow with posterodorsal black stripe (Fig. 44); mesonotum black with two small spots on mesoscutal middle lobe, axilla, and metanotum yellow; mesepisternum black with almost upper 
half yellow; metanotum yellow (Figs 44, 45). Legs yellow, femora black with yellow apex; apical 4 tarsal segments brown. Abdomen black with yellow bands; basal plates black; tergite 2 yellow; tergites 3 and 4 with lateral yellow stripes, tergites 5-8 with complete posterior yellow bands; tergite 9 yellow on posterior quarter. Wings hyaline, veins and stigma brown. Head: Antenna 17-segmented, 1.4X head width; scape:pedicel: $1^{\text {st }}$ antennomere as 1.0:0.3:0.9; pedicel 1.3X longer than broad. Malar space narrow, about half diameter of an ocellus. Lower interocular distance 1.1X eye height; inner margins of eyes slightly diverging below (Fig. 42). Labial palpus 4-segmented; maxillary palpus 4-5 segmented (difficult to see). Frons longitudinally striate, finely reticulate and microsculptured between carinae (Fig. 42). Carina extending from lower outer orbits through malar area and inner orbits to top of eye (Fig. 43). Gena and vertex smooth and shining, with 10 or more fine striae on gena and with transverse band of fine longitudinal striae between eyes dorsal to hind ocelli. Thorax: Mesoscutum, mesoscutellum, and axilla densely reticulate (Fig. 45). Propleuron shining, very finely punctate. Pronotum smooth and shining with fine striae and some reticulations dorsally; mesepisternum shining with scattered large punctures separated by flat interspaces mostly about equal to a puncture diameter; mesepimeron shining, smooth, with band of short striae on posterior margin (Fig. 44). Metapleuron finely striate. Fore tarsal claw with inner tooth; middle and hind tarsal claws simple. Hind basitarsus $0.7 \mathrm{X}$ length of remaining tarsal segments combined. Abdomen: Shining with fine microsculpture. Length of basal plates 1.1X length of second tergite. Sheath: valvifer2:hind tibia as 0.7:1.0:1.1.

Male: Unknown.

Holotype: Female, "Indonesia: W. Kalimantan, Gunung Palung Nat. Pk., June 15-August 15, 1991, Darling, Rosichon, Sutrisno 115910116; Cabang Panti Res. Sta., 1¹5'S, 1105'E, 1 rain forest, Malaise trap head sandstone - light gap" (Museum Zoologu Bogor, Bogor, Indonesia).

Etymology: Named for D. Christopher Darling, Royal Ontario Museum, Toronto, Canada, who brought this specimen to my attention.

\section{Remarks:}

The color pattern of the head, thorax, and abdomen (Figs 40-44) as well as the reticulate sculpturation of the mesonotum, the relatively straight longitudinal sculpturation of the anterior vertex and frons, and simple middle and hind tarsal claws separate this species from other species on Indoxiphia. I have not seen a transverse band of striae behind the ocelli in other species.

\section{Indoxiphia falcata SMITH, new species}

(Figs 47-50)

\section{Diagnosis:}

Female with middle and hind tarsal claws simple; hind tarsal claws long, sickle-shaped. Female entirely orange; antenna black.

\section{Female:}

Length, $13.0 \mathrm{~mm}$. Color: Orange; antenna black. Wings hyaline, veins and stigma brownish. Head: Antenna 14-segmented, length $1.3 \mathrm{X}$ head width; scape:pedicel: $1^{\text {st }}$ antennomere as 1.0:0.6:0.8; pedicel 2.0X longer than broad. Malar space distinct, narrow, about half diameter of an ocellus; carina extending through malar area below eye. Lower interocular distance 1.1X eye height; inner margins of eyes slightly diverging below (Fig. 48). Labial palpus 4-segmented; 
maxillary palpus 4-5 segmented (difficult to see). Frons, ocellar area, and interantennal area with longitudinal carinae mixed with reticulations (Fig. 48). Gena and vertex smooth, shining, with scattered fine punctures; small area behind lateral ocelli finely reticulate; 5-8 fine striae on gena. Thorax: Mesoscutum, axilla, and mesoscutellum evenly, densely reticulate (Fig. 50). Propleuron shining with punctures (Fig. 49). Pronotum shining, finely reticulate, reticulation denser on upper lateral corners (Fig. 49). Mesepisternum coarsely reticulate, dulled with microsculpture; mesepimeron dull with microsculpture, narrow band of striae on posterior margin (Fig. 49). Metapleuron reticulate (Fig. 49). Fore tarsal claw with long inner tooth, about half length of outer tooth; middle and hind tarsal claws simple; hind tarsal claw long, slender, sickle-shaped; middle and hind tarsal claws larger than fore tarsal claw. Hind basitarsus 1.1X longer than remaining tarsal segments combined. Abdomen: Shining, very fine microsculpture denser anterolaterally on basal plates and laterally on $2^{\text {nd }}$ tergite. Length of basal plates $1.1 \mathrm{X}$ length of $2^{\text {nd }}$ tergite. Sheath: valvifer 2 :hind tibia as 0.6:1.0:0.9.

Male: Length, $7.5 \mathrm{~mm}$. Antenna black with scape and pedicel orange. Head orange with interocellar area, stripe from each lateral ocellus to antennal insertions, stripe between antennal insertions, and lateral corner of clypeus black. Thorax black with following yellow: lateral corners of pronotum, stripe on ventral margin of lateral pronotum, dorsoposterior half of mesepisternum, posterior two-thirds of mesoscutal middle lobe, axilla, posterior corner of mesoscutellum, metanotum, mesepimeron, and metapleuron; mesosternum and mesoscutellum orange. Legs entirely orange yellow. Abdomen black above, almost confluent yellow marks laterally on tergites 2-7, large spot on tergite 8; sternites yellow. All tarsal claws of similar size, each with inner tooth.

Holotype: Female, labeled “New Ireland, Schleinitz Mts., Lelet Plateau, Oct. 1959," “W. W. Brandt, Collector, Bishop" (BPBM).

Other specimens examined: "New Ireland (SW), Ridge above "Camp Bishop" $15 \mathrm{~km}$ up Kait R., 250-500 m, VI-11-1956," "J. L. Gressitt, Collector" (1 ơ, BPBM); same except "250-750 m," "VII-14-1956" and second label "Light Trap, J. L. Gressitt" (1 $0^{\text {× }}$, BPBM).

Etymology: From the Latin adjective, falcatus, sickle-shaped, referring to the long curved hind claws.

\section{Remarks:}

The two males are very similar except the black stripes on the frons are fainter in one of the specimens. I am quite certain they are the male of this species since sculpturation is very similar to the female. The darker coloration is a common sexual dimorphism in xiphydriids.

The rather long, curved tarsal claws, largely orange color, and reticulate sculpture of the mesonotum will distinguish the female of this species.

\section{Indoxiphia fijiensis SMITH, new species}

(Figs 51-53)

\section{Diagnosis:}

Fore tarsal claw with minute inner tooth, middle and hind tarsal claws simple. Mesonotum black. Reticulate sculpture of mesoscutum coarse, with transverse pattern at center; sculpture of mesoscutellum in transverse pattern. 


\section{Female:}

Length, $8.5 \mathrm{~mm}$. Color: Antenna black. Head brownish to black, interantennal area, clypeus, spot below anterior ocellus, inner orbits and genae mostly yellowish (Fig. 51). Thorax dark brownish to black with following yellowish: dorsal and ventral margins of pronotum, dorsal stripe on mesepisternum; metanotum dark brown. Legs orange brown, basal $2 / 3$ hind tibia and hind basitarsus white. Abdomen dark brown; base of sheath and basal part of valvifer 2 yellowish. Wings hyaline, veins and stigma black. Head: Antenna 13-segmented; length 1.7X head width; scape:pedicel: $1^{\text {st }}$ antennomere as 1.0:0.5:0.7; pedicel 2.0X longer than broad. Malar space distinct but narrow; carina below eye in malar area. Lower interocular distance subequal to eye height; inner margins of eyes slightly diverging below (Fig. 51). Labial palpus 4-segmented, with apical segment not noticeably enlarged; maxillary palpus apparently 4-segmented (difficult to see). Frons and ocellar area reticulate with several longitudinal carinae from lateral area of ocelli extending to clypeus (Fig. 51). Gena and vertex shining with few widely scattered punctures; fine punctures immediately posterior to hind ocelli; gena with several striae. Thorax: Mesoscutum reticulate, sculpture oriented transversely (Fig. 53). Axilla reticulate; mesoscutellum with finer reticulations than mesoscutum, sculpture oriented transversely (Fig. 53). Propleuron shining, with widely scattered punctures (Fig. 52). Pronotum smooth and shining, reticulate on upper lateral corners (Fig. 52). Mesepisternum dull with microsculpture, large punctures on lower two-thirds, separated by narrow ridges less than puncture diameters; mesepimeron microsculptured, dull; with narrow band of striae on posterior margin (Fig. 52). Metapleuron reticulate (Fig. 52). Forewing with 2A slightly faded toward apex. Fore tarsal claw with minute inner tooth near center; middle and hind tarsal claws simple, much larger than fore tarsal claw. Hind basitarsus 0.9X length of remaining tarsal segments combined. Abdomen: Shining but slightly dulled with microsculpture, microsculpture denser on anterolateral portions of basal plates. Length of basal plates 1.3X length of $2^{\text {nd }}$ tergite. Sheath plus valvifer 2 long, almost equal to length of hind femur, tibia, and tarsus combined. Sheath:valvifer 2:hind tibia as 0.7:1.0:0.8.

Male: Unknown.

Holotype: Female, labeled "Fiji, Galoa on Palaquium [?], 11.VII-1973, H. Roberts, C.I.E. A6503, F213," "Indoxiphia Maa ?sp, det J. Quinlan, 1973" (BMNH). Parts of the locality data are handwritten and difficult to interpret.

Etymology: Named after the type locality.

\section{Remarks:}

This species is predominately black to dark brown with yellowish margins on the head, pronotum, and mesepisternum. Segments of the maxillary palpus are not discernable. The sculpture on the mesonotum (Fig. 53) is unique in that the cavities formed by the reticulations are much larger than those of other species of the genus and are transversely oriented.

This is the first record of a xiphydriid from Fiji and the most eastern record for the genus. The only species of Symphyta known from Fiji is Guiglia rubicunda Schmidt (in Vilhelmsen \& Sмiтн 2002) (Orussidae).

\section{Indoxiphia laeviceps (F. SMITH), new combination}

(Figs 54-57)

Xiphidria (!) laeviceps F. SMith 1861: 137.-Westwood 1874: 112.-Dalla Torre 1894: 396.-Konow 1897: 303, 308, 311.-Konow 1905a: 4.-Konow 1905b: 43, 55.-Hedicke 1938: 8. 
Moaxiphia laeviceps: MAa 1949: 29.

Cingalixiphia laeviceps: Benson 1954: 161.-Smith 1978: 103.-Basibuyuk and Quicke 1995: 158.JenNings et al. 2007: 23.

\section{Diagnosis:}

Apical 7-8 antennal flagellomeres white. Middle and hind tarsal claws simple. Mesonotum black, only axillae white; metanotum with two white spots. Abdomen with first tergite yellowish, yellow lateral spots on tergites 2 and 4-6, and yellow lateral bands on tergites 8 and 9 .

\section{Female:}

Length, $13.0 \mathrm{~mm}$. Color: Antenna black with apical 7-8 flagellomeres white. Head black with spot on inner side of each antennal insertion and inner orbit from top of eye through malar area and most of gena to posterior margin of vertex yellow (Fig. 54). Thorax black with posterior margin and lateral corners of pronotum, anteroventral margin of pronotum, spot on upper angle of mesepisternum, axilla, and two spots on metanotum yellow. Legs black with outer surfaces of coxae, basal third to half of hind tibia, and hind basitarsus white. Abdomen black with basal plates, lateral spots on tergites 2 and 4-6, posterior band on tergite 8 not meeting at center, complete posterior band on tergite 9, and spot at apex of tergite 10 yellow. Wings hyaline, veins and stigma black. Head: Antenna 14-segmented; length $1.5 \mathrm{X}$ head width; scape:pedicel: $1^{\text {st }}$ antennomere as 1.0:0.5:0.8; pedicel more than 2.3X longer than broad. Malar space narrow, about half diameter of an ocellus. Lower interocular distance subequal to eye height; inner margins of eyes diverging below (Fig. 54). Labial palpus 4-segmented. Maxillary palpus 4-5 segmented, more slender and shorter than labial palpus, about equal to length of first labial palpal segment. Frons with longitudinal curved carinae from ocelli through interantennal area onto clypeus, somewhat more reticulate at center and finely reticulate between carinae; ocellar area reticulate (Fig. 54). Gena and vertex smooth and shining, with fine scattered punctures; gena with 7-9 striae. Thorax: Mesoscutum, axilla, and mesoscutellum evenly, densely reticulate (Fig. 55). Propleuron shining with scattered punctures (Fig. 55). Pronotum shiny, smooth ventrally, reticulate on upper half (Fig. 55). Mesepisternum shining with large punctures separated by shining interspaces slightly less than puncture diameters; microsculptured posteriorly; mesepimeron finely striate (Fig. 55). Metapleuron reticulate (Fig. 55). Fore tarsal claw with small inner tooth at center of claw; middle and hind tarsal claws simple (Fig. 57). Hind basitarsus equal in length to remaining tarsal segments combined. Abdomen: Shining with fine microsculpture. Length of basal plates $1.4 \mathrm{X}$ length of $2^{\text {nd }}$ tergite. Sheath:valvifer 2:hind tibia as 0.7:1.0:1.1.

Male: Unknown.

Type: A syntype female at OUMNH, labeled "Amb." (white, round, lettering faded and hardly visible), "TYPE, O.U.M." (white, round, with red border), "Xiphidria laeviceps Smith" (handwritten), "Oxford University Museum of Natural History (OUMNH)" Smith (1861) described the female from "Ambyona." The number of specimens was not stated; thus, I am designating this specimen a lectotype to ensure nomenclatural stability.

Other specimens: "L. J. Toxopeus, Buru - Station 8," “15 Febr. 1922," "Moluccas, Buru," "Cingalixiphia laeviceps Smith det. R. B. Benson 1953." (1 , BMNH); "Bulolo, N. Guinea, I.15-II-14.1979, 800 m, J. Sedlacek” (1 ㅇ, AEIC).

\section{Remarks:}

This is the only known species of Indoxiphia with a mostly white antennal flagellum. This plus the color pattern of the head, thorax (Figs 52-54), and abdomen and simple middle and hind 
tarsal claws will separate this species. I have compared the type of I. laeviceps and the specimen identified by Benson from Buru and confirm that they are conspecific.

\section{Indoxiphia maai, SMITH, new species}

(Figs 58-61)

\section{Diagnosis:}

Fore- and midtarsal claws with inner tooth; hind tarsal claw simple. Abdomen orange yellow with apex black. Mesepisternum shining with widely spaced punctures.

\section{Female:}

Length, $6.5 \mathrm{~mm}$. Color: Head yellow with transverse black stripe on vertex between top of eyes, and extending through ocelli halfway down frons, with narrow extensions to each antennal insertion and centrally to interantennal area (Fig. 59). Thorax black with lateral corners of pronotum, ventroanterior margin of lateral pronotum, two lateral spots near apex of mesoscutal middle lobe, posterior half of axilla, V-shaped stripe on lateral and posterior margins of mesoscutellum, metanotum, upper third of mesepisternum, and metapleuron yellow (Figs 59, 61). Legs yellow. Abdomen orange yellow with dorsum of tergites 7 and 8 and entire tergite 9 black; lateral white spots on $2^{\text {nd }}$ tergite; valvifer 2 orange; sheath black, orange basally. Wings hyaline; veins and stigma black. Head: Antenna 14-15 segmented; length 1.8X head width; scape:pedicel: $1^{\text {st }}$ antennomere as 1.0:0.5:0.9; pedicel 2.0X longer than broad. Malar space narrow, less than half diameter of an ocellus; carina in malar area just below eye. Lower interocular distance subequal to eye height; inner margins of eyes diverging below (Fig. 59). Labial palpus 4-segmented; maxillary palpus possibly 5-segmented (difficult to see). Frons with longitudinal carinae, carinae extending from ocelli through interantennal area, lateral carinae curved; intercarinal areas smooth and shining (Fig. 59). Gena and vertex shining, only few scattered punctures; gena with 6-8 fine striae. Thorax: Anterior third of mesoscutal middle lobe shining, punctate, posterior two-thirds reticulate with irregular transverse carinae at center; lateral lobes mostly shining and punctate, inner margins with few short carinae (Fig. 61). Axilla shining, reticulate; mesoscutellum reticulate, reticulations smaller than those at center of mesoscutum (Fig. 61). Propleuron shining with few scattered punctures (Fig. 60). Pronotum mostly shining, more reticulate on upper lateral corners (Fig. 60). Mesepisternum shining with few widely spaced punctures mostly separated by flat interspaces several times puncture diameters; mesepimeron finely striate (Fig. 60). Metapleuron finely reticulate (Fig. 60). Fore and midtarsal claws with inner tooth; inner tooth half or slightly less than length of outer tooth; hind tarsal claw simple. Hind basitarsus equal in length to remaining tarsal segments combined. Abdomen: Shining with fine microsculpture, microsculpture denser on anterolateral portion of basal plates. Length of basal plates subequal to length of $2^{\text {nd }}$ tergite. Sheath:valvifer 2:hind tibia as 0.8:1.0:1.0.

Male: Unknown.

Holotype: Female, labeled "New Guinea: Papua, Brown River, Aug. 20, 1959,” “T. C. Maa Collector, Bishop" (BPBM).

Etymology: Named for T.C. Maa, collector of the species.

\section{Remarks:}

The mostly orange abdomen with the apex black, only hind claws simple, color pattern of the head and thorax (Figs 56-59), and very shining and smooth mesepisternum with only a few scattered pits will distinguish this species from other species of Indoxiphia. 


\section{Indoxiphia papuaensis SMITH, new species}

(Figs 62-64)

\section{Diagnosis:}

Fore and midtarsal claws with inner tooth; hind tarsal claw simple. Orange to yellow with black band on head between top of eyes and extending anteriorly through ocelli to lower frons and on apex of abdomen black. Mesonotum with coarse, transversely directed sculpturation.

\section{Female:}

Length, $11.5 \mathrm{~mm}$. Color: Antenna black with scape and pedicel dark brown. Head yellow with black transverse stripe on vertex between eyes and broad stripe anteriorly through ocelli to lower frons (Fig. 62); narrow black stripe on center of postocellar area from black area to hind margin of head; apex of mandible red brown; palpi brown. Thorax orange, yellowish marks on lateral corners of pronotum and upper margin of mesepisternum. Legs orange. Abdomen orange; tergites 2-4 with small lateral yellow spots, tergite 7 black dorsally at center; segment 8 black except narrow anterior margin; segment 9 black; cercus, sheath, and basal plates orange, apex of sheath black. Wings yellow, apex and veins at apex black, veins basal to stigma brown; costa brownish orange, subcosta black. Head: Antenna broken apical to segment 9; scape:pedicel: $1^{\text {st }}$ antennomere as 1.0:0.4:0.8; pedicel 2.0X longer than broad. Malar space narrow, less than one-quarter diameter of an ocellus. Lower interocular distance subequal to eye height; inner margins of eyes diverging below (Fig. 62). Labial palpus 4-segmented; maxillary palpus possibly 5-segmented (difficult to see). Frons with longitudinal carinae extending from ocelli through clypeus; reticulations between antenna and mostly reticulate on lateral areas of frons (Fig. 62). Vertex and gena shining; few transverse ridges and punctures immediately behind ocelli; gena with 6-8 fine striae. Thorax: Mesoscutum, axilla, and mesoscutellum evenly and coarsely reticulate, sculpturation transversely oriented (Fig. 64). Propleuron smooth and shining. Pronotum shining, reticulate dorsally and on upper lateral corners (Fig. 63). Mesepisternum dulled with microsculpture, with large punctures separated by narrow ridges except on posterior margin; mesepimeron shining, smooth, with narrow row of fine striae on posterior margin (Fig. 63). Metapleuron finely reticulate (Fig. 63). Fore and midtarsal claws both with long inner tooth; hind tarsal claw simple. Hind basitarsus 1.1X length of remaining tarsal segments combined. Abdomen: Shining, anterolateral portion of basal plates finely sculptured. Length of basal plates subequal to length of 2 nd tergite. Sheath: valvifer 2 :hind tibia as $0.7: 1.0: 0.8$.

Male: Unknown.

Holotype: Female, labeled: "New Guinea: Papua, Brown River, May 21, 1956," “E. J. Ford, Jr. Collector" (BPBM).

Etymology: Named for the country of collection.

\section{Remarks:}

This species and I. maai are the only two with only the hind tarsal claws simple, and both have an orange abdomen with the apex black. Indoxiphia papuaensis, however, has an orange thorax and a dull, microsculptured mesepisternum with large, almost confluent punctures (see Figs 58-64). 


\section{Indoxiphia quadricincta (BENSON)}

(Figs 65-68)

Xiphydriola quadricincta Benson 1935: 168.-Hedicke 1938: 13.

Indoxiphia (Indoxiphia) quadricincta: MAA 1949: 67, 169.-SмIтн 1978: 107.

\section{Diagnosis:}

Middle and hind tarsal claws simple. Axillae, mesoscutellum, and metanotum white. Abdomen with white to yellow band on tergites 2, 5, 6, and 8 and lateral yellow spots on tergites 3 and 4 .

\section{Female:}

Length, $10.0 \mathrm{~mm}$. Color: Head yellow with broad transverse stripe on vertex between eyes and broad black band extending anteriorly through ocelli to lower frons; spot below anterior ocellus yellow (Figs 65, 66). Thorax black with most of pronotum, lateral stripes on mesoscutal middle lobe, axillae, mesoscutellum, metanotum, broad posterior stripe on posterior margin of mesepisternum, upper portion of mesepimeron, and upper portion of metapleuron yellow to white (Figs 67, 68). Abdomen black with broad yellow bands on tergites 2, 5, 6, 8, and apex of 9, and lateral spots on 3 and 4 (Fig. 65). Legs yellow with most of femora except apices, extreme apex of hind tibia, and apical 4 tarsal segments black. Wings hyaline, veins and stigma black. Head: Antenna 14-segmented; length 1.6X head width; scape:pedicel: $1^{\text {st }}$ antennomere as 1.0:0.4:0.8; pedicel 2.0X longer than broad. Malar space distinct, narrow, equal to about half diameter of an ocellus; carina below eye in malar area. Lower interocular distance 1.2X eye height; inner margins of eyes diverging below (Fig. 66). Labial palpus 4-segmented; maxillary palpus 5 -segmented. Frons, ocellar area, and interantennal area reticulate and with longitudinal carinae (Fig. 66). Gena and vertex smooth and shining with few scattered punctures, gena with 6-9 fine striae. Thorax: Mesoscutal middle lobe with anterior third smooth and shining with punctures, posterior two-thirds with coarse, large, reticulations (Fig. 67). Axilla and mesoscutellum shining, finely reticulate (Fig. 67). Propleuron shining, densely punctate (Fig. 67). Pronotum smooth and shining, few reticulations on upper lateral corner (Fig. 67). Mesepisternum shining with small scattered punctures separated by flat interspaces equal to several times puncture diameters; mesepimeron smooth and shining with narrow row of striae on posterior margin (Fig. 66). Metapleuron reticulate (Fig. 68). Fore tarsal claw with inner tooth; middle and hind tarsal claws simple. Hind basitarsus 0.9X length of remaining tarsal segments combined. Abdomen: Shining, with fine microsculpture. Length of basal plates subequal to length of $2^{\text {nd }}$ tergite. Sheath:valvifer 2:hind tibia as 0.7:1.0:1.0.

Male: Unknown.

Holotype: Female labeled "Pemalung, Pekalongan Province, Central Java, VII.1928, L. G. E. Kalshoven" (RMNH).

\section{Remarks:}

This species was originally placed in Xiphydriola, but Xiphydriola has all tarsal claws simple and shorter antennae. Indoxiphia quadricincta may be distinguished by the color pattern of the head and body (Figs 65-68), especially the yellow axillae, mesoscutellum, and metanotum, simple middle and hind tarsal claws, and smooth and shining mesepisternum with widely spaced punctures. 


\section{Indoxiphia schiffi SMITH, new species}

(Figs 69-73)

\section{Diagnosis:}

Middle and hind tarsal claws simple. Frons with curved carinae. Head yellow with 3 longitudinal black marks on vertex. Mesoscutellum yellow with broad black medial stripe. Abdominal tergites 1 and 2 mostly yellow, tergites 3-6 with lateral yellow spots.

\section{Female:}

Length, $12.0 \mathrm{~mm}$. Color: Head yellow with three longitudinal black marks, one at center enclosing ocelli, the other two on each side from center of vertex to top margin of each eye (Figs 70, 72). Thorax (Figs 71, 73) with pronotum mostly yellow with black spot at center on lateral protons; stripes on lateral margins of mesoscutal middle lobe, spot laterally on mesoscutal lateral lobe, axilla, most of mesoscutellum except medial black stripe, metanotum, and stripe on posterior margin of mesepisternum yellow. Legs black with fore tibia, foretarsus, midtibia and most of midbasitarsus white to yellowish; hind tibia with basal half white, apical half darker, light blackish, hind basitarsus white with extreme apex black. Abdomen black, tergites 1 and 2 yellow orange with anterior and posterior margins black; tergites 3-6 with lateral white spots. Wings hyaline, costal cell darkened; veins and stigma black. Head: Antenna 15-segmented; length 1.3X head width; scape:pedicel: $1^{\text {st }}$ antennomere as 1.0:0.5:0.7; pedicel 2.1X longer than broad. Malar space narrow but distinct, less than half diameter of an ocellus. Lower interocular distance subequal to eye height; inner margins of eyes diverging below (Fig. 70). Labial palpus 4-segmented; maxillary palpus possibly 5-segmented (difficult to see). Frons with longitudinal carinae, from center of frons and inner orbits, extending in circular fashion to interantennal area and clypeus; ocellar area and immediately below ocellar area punctate (Fig. 70); gena and vertex shining with few widely scattered punctures and few small punctures and oblique ridges immediately behind ocelli and scattered punctures and 6-9 fine striae on gena (Fig. 72). Thorax: Mesoscutal middle lobe with irregular transverse carinae; lateral lobes shining laterally, irregularly carinate on inner margins (Fig. 73). Axilla reticulate, without transverse pattern; mesoscutellum with irregular transverse carinae at center, fading to finer reticulations laterally (Fig. 73). Propleuron shining (Fig. 73). Pronotum with irregular carinae, more reticulate on upper lateral corners; mesepisternum shining to dulled with microsculpture dorsally, upper two-thirds wrinkled to reticulate, shinier ventrally with scattered punctures separated by flat interspaces several times puncture diameters at center, and lower third shining without sculpture; mesepimeron shining with broad posterior band of striae (Fig. 73); metapleuron reticulate (Fig. 73). Fore tarsal claw with inner tooth, about half length of outer tooth; middle and hind tarsal claws simple, both larger than fore tarsal claw and hind tarsal claw larger than midtarsal claw; hind tarsal claw long, slender, sickle-shaped. Hind basitarsus 0.9X length of remaining tarsal segments combined. Abdomen: Shining with fine microsculpture, sculpture fine on anterolateral portion of basal plates. Length of basal plates subequal to length of $2^{\text {nd }}$ tergite. Sheath:valvifer 2:hind tibia as $0.8: 1.0: 1.1$.

Male: Unknown.

Holotype: Female, labeled: "Papua New Guinea Gulf: Ivimka Res. Station, Lakekamu Basin, $120 \mathrm{~m}, 7^{\circ} 44^{\prime} \mathrm{S}, 146^{\circ} 30^{\prime} \mathrm{E}, 21 . \mathrm{III} .2000$, MT, T. Sears” (UCDC).

Etymology: Named for Dr. Nathan M. Schiff, U. S. Forest Service, Stoneville, Mississippi, who brought this specimen to my attention. 


\section{Remarks:}

This species has the middle and hind tarsal claws simple, almost semicircular carinae on the frons, and transversely directed sculpturation on the mesonotum. The color pattern of the abdomen, with the first two tergites almost entirely yellow and only lateral yellow spots on tergites 3-6, and broad medial black stripe of the mesoscutellum are distinctive.

\section{Indoxiphia sumatra SMITH, new species}

(Figs 74-76)

\section{Diagnosis:}

Middle tarsal claws and presumably hind tarsal claws simple. Frons with coarse, almost straight carinae. Mesepisternum with large, confluent punctures separated by narrow ridges. Mesoscutellum and metanotum yellow. Abdomen with most of tergites 2 and 3 and lateral stripes on tergites 6-8 yellow.

\section{Female:}

Length, $7.0 \mathrm{~mm}$. Color: Antenna brownish. Head black with spot below anterior ocellus, circular spot on inner and upper margin of each antennal insertion, stripe on inner orbits from top of eye through malar area, gena, and extending to top of eye yellow. Thorax black with lateral corners of pronotum, upper quarter of mesepisternum, inverted U-shape stripe on mesoscutal lateral lobe, axilla, mesoscutellum except black spot anteriorly, and metanotum yellow. Legs yellow. Abdomen black with yellow bands on tergites 2 and 3, tergites 6-8 each with yellow stripe not meeting on meson; sheath black with margins narrowly yellowish. Wings hyaline, veins and stigma brownish. Head: Antenna 13-segmented; length 1.5X head width; scape:pedicel: $1^{\text {st }}$ antennomere as 1.0:0.3:0.4; pedicel 1.7X longer than broad. Malar space about equal to one-quarter diameter of an ocellus. Lower interocular distance $1.2 \mathrm{X}$ eye height; inner margins of eyes diverging below (Fig. 74). Labial palpus 4-segmented. Maxillary palpus 4 or 5 segmented (difficult to see). Frons with longitudinal ridges extending from just below front ocellus onto clypeus; area between ridges shining with few punctures (Fig. 74); gena and vertex smooth and shining with few scattered punctures, gena with 6-9 fine striae. Thorax: Mesoscutal middle lobe reticulate, smoother on anterior margin; lateral lobes smooth and shining, punctate on inner margins (Fig. 76). Axilla and mesoscutellum finely reticulate, shining (Fig. 76). Propleuron smooth and shining. Pronotum shining, smooth, few reticulations on upper lateral corners and diagonal stripe at center (Fig. 75). Mesepisternum shining with large punctures separated by narrow ridges; mesepimeron shining, with band of striae on posterior half (Fig. 75). Metapleuron reticulate. Hind wing with cell Rs absent, $\mathrm{M}$ present. Foreclaw bifid; midclaw simple, long, falcate (hind claw not visible). Both hind tarsi broken. Abdomen: Shining with fine microsculpture. Length of basal plates 1.5X length of 2nd tergite. Sheath:valvifer 2:hind tibia as 0.8:1.0:0.8.

Male: Unknown.

Holotype: Female, labeled "Museum Leiden, N Sumatra: Bivouac One, Mt. Bandahara, 3 43'N. - 97 41'E., 25.VI-5.VII-1972, J. Krikken, no. 23, ca 810 m," "Submontane Multistratal evergreen forest, at light" (RMNH).

Etymology: Named for the type locality, a noun in apposition. 


\section{Remarks:}

Indoxiphia sumatra has the middle tarsal claws and probably the hind tarsal claws simple. Although the hind tarsal claws are absent, I know of no other instance where the hind tarsal claws would have an inner tooth if the midtarsal claws are simple. Other distinctive characters are the shining mesepisternum shining with large closely set punctures separated by narrow ridges, the yellow mesoscutellum, axillae, and the narrow posterior corners of the pronotum, and the yellow bands on tergites 2 and 3 and lateral yellow stripes on tergites 6-8. Cell Rs in the hind wing is absent which is the only known instance of the lack of a hind wing cell in Indoxiphia. Whether or not this is useful cannot be determined from a single specimen.

\section{Unassociated Male}

\section{Indoxiphia testacea (MocSÁRY), new combination}

(Figs 77-81)

Xiphydria testacea Mocsáry 1900: 127.-Konow 1905a: 4.-Konow 1905b: 199.-Hedicke 1938: 12.

Moaxiphia testacea: MAa 1949: 29.

Rhysacephala testacea: Benson 1954: 160.-SMith 1978: 111.-Jennings et al. 2007: 23.

\section{Diagnosis:}

The male is known for only one other species of Indoxiphia, I. falcata. Indoxiphia testacea is almost entirely yellow orange and shining, with the mesepisternum shining with large scattered punctures (Fig. 81); I. falcata has parts of the head and dorsum of abdomen black, is slightly dulled with surface microsculpture and has smaller, more closely set punctures on the mesepisternum (similar to Figs 48, 50).

Female: Unknown.

\section{Male:}

Length, $6.0 \mathrm{~mm}$. Color: Yellow with blackish areas on ocellar area and apex of abdomen. Wings hyaline, veins and stigma brownish. Head: Antenna broken beyond $11^{\text {th }}$ segment; scape:pedicel: $1^{\text {st }}$ antennomere as 1.0:0.4:0.9; pedicel 2.1X longer than broad (Fig. 78). Malar space linear Occipital carina very narrow, less than one third diameter of an ocellus. Lower interocular distance 1.1X eye height; inner margins of eyes almost straight (Fig. 79). Labial palpus 4-segmented, apical segment slightly enlarged apically; maxillary palpus difficult to see. Frons with longitudinal carinae from just below ocelli extending onto clypeus; interspaces shining, without sculpture (Fig. 79). Gena and vertex smooth and shining with very few scattered punctures (Fig. 80); gena with 5-6 fine striae. Thorax: Mesoscutum, axilla, and mesoscutellum rather evenly reticulate (Figs 78, 80). Propleuron smooth, shining. Pronotum smooth and shining, few reticulations on upper lateral corner (Fig. 81). Mesepisternum shining, with scattered punctures separated by shiny interspaces equal to or slightly more than puncture diameters; mesepimeron shining with narrow row of carinae on posterior margin (Fig. 81). Metapleuron shining, finely reticulate (Fig. 81). All tarsal claws with inner tooth, inner tooth of each claw long, close to and more than half length of outer tooth; claws slightly increasing in size with hind claw largest. Hind basitarsus 0.9X length of remaining tarsal segments combined. Abdomen: Shining, fine microsculpture on anterior margin of each tergite. Length of basal plates subequal to length of tergite 2 .

Holotype: Described from a male from "Nova-Guinea-Germanica (Gingala, 20./X. 1898, a Dom. L. Biró detecta); specimen unicum (Mus. Hung.).” MocsÁry stated "specimen unicum.” The 
holotype, in HNHM, is labeled "N. Guinea, Biro 1898," "Gingala 20.x.98," "Typus Xiphydria testacea Mocs."

\section{Remarks:}

It is sometimes difficult to place unassociated males even to genus, but the longitudinal sculpture of the frons, short maxillary palpus, striae on the gena, and general sculpture of the thorax associate this species with Indoxiphia. Whether or not it is a male of another species described here will have to await association of sexes. It appears to be most similar to $I$. maai, especially the similarity of the carinae on the frons and shining mesepisternum, but association is not certain. Since I have seen the holotype, I included a detailed description.

\section{Obesaxiphyda SMITH, new genus}

Type species: Xiphydria heritierae RoHwer.

\section{Description:}

Antennal flagellum strongly swollen basally, sharply tapering to apex (Figs 81, 85); 17-18 segmented; pedicel dorsoventrally flattened, about 2.0X longer than broad on flattened surface; eyes small, oval, lower interocular distance greater than eye height, inner margins of eyes subparallel, eyes removed from hind margin of head in lateral view (Figs 82, 86, 87), in dorsal view, straight behind eyes, then sharply narrowing; malar space about equal to diameter of front ocellus; genal carina absent; labial palpus 3-4 segmented; maxillary palpus 4-5 segmented, much narrower in diameter than labial palpus and less than $2 \mathrm{X}$ length of labial palpus; gena and vertex smooth and shining; frons densely sculptured. Pronotum rounded in laterally, very shallowly concave near anterolateral portion but not evident in dorsal view; pronotal collar excavation broadly rounded (Fig. 89). Tarsal claws of females with inner tooth on fore- and midclaws, hind claw simple; each tarsal claw of males with inner tooth which is nearly as long as outer tooth and closely appressed to outer tooth (as in Fig. 113). Forewing: Costal cell narrow, width less than $2 \mathrm{X}$ width of costa. Hind wing: Cells Rs and M present or absent, normally without anal cell (Fig. 91); if cell A present, vein $1 \mathrm{~A}$ straight, $2 \mathrm{~A}$ abruptly curved up at apex meeting $1 \mathrm{~A}$ to form cell.

Etymology: From the Latin, obesus, swollen, referring to the swollen antennae. Gender: feminine.

\section{Remarks:}

The swollen antennae of the female, rounded pronotum lacking a deep excavation laterally, simple hind tarsal claws of the female, and appressed teeth of the tarsal claws of the male are characteristic for this genus. Females of Lataxiphyda have a stout antenna, but they are not so swollen as in Obesaxiphyda. Lataxiphyda is separated by the broad costal cell of the forewing and depressed area on the head posterior to the ocelli.

This genus includes Obesaxiphyda heritierae (RoHwer), n. comb., from India, O. borneensis (Rohwer), n. comb., from Sabah and Selangor, Malaysia, and O. banahao, n. sp., from the Philippines. Obesaxiphyda is distributed from eastern India to the Philippines and insular Malaysia.

RoHwer (1921) described the type species, O. heritierae, from "Sunderbans, Bengal, British India" (types at USNM, examined). It is similar to the description of $O$. borneensis except for characters noted in the Remarks secton of that species. The differences may prove variable, buat I prefer to 
keep the two separate until more material is available from southeastern Asia. I have seen only two specimens from localities between India and insular Malaysia. A specimen examined from Thailand (NW Chaiangmai Prov.,Chiangdao, 450 m, IV-5-11-1958, T.C. Maa Collection No. 334 , at BPBM) is very similar to $O$. heritierae but differs by lacking white spots on the abdomen and having more darkly infuscated wings. It could be a variety of $\mathrm{O}$. borneensis or $\mathrm{O}$. heritierae or represent another species. A specimen cited under O. borneensis from Selangor, Malaysia, is identical to $O$. borneensis.

\section{Key to Species}

1. Head red; pronotum with yellow stripe laterally (Fig. 90); interantennal area reticulate (Fig. 86) borneensis (ROHWER)

Head black with continuous yellow stripe on inner orbits through malar area and gena and meeting on vertex (Figs 82, 83); pronotum black laterally; interantennal area with longitudinal carinae extending onto clypeus (Fig. 82) banahao, n. sp.

\section{Obesaxiphyda banahao SMITH, new species}

(Figs 82-85)

\section{Diagnosis:}

Head black except for continuous yellow stripe on inner orbits to genae and vertex; pronotum black; abdomen black. Interantennal area with longitudinal carinae.

\section{Female:}

Length, $15.0 \mathrm{~mm}$. Color: Antenna black. Head black; mandible yellow with apex black; continuous yellow band from near top of inner orbit through malar space and gena and meeting on posterior vertex (Figs 82, 83). Thorax black with spot at center of pronotum, small spot on lateral corners of pronotum, narrow streak on upper margin of mesepisternum, and small spot posterior to each cenchrus yellow. Abdomen black with lateral yellow spots on tergites 1, 2 and 3-6, large on tergite 2, small but increasing in size from tergites 3-6. Foreleg black with spot at apex of femur and basal $1 / 5$ of tibia yellow, tarsus brown; midleg black with apex of femur and basitarsus yellow; hind leg black with basal 1/3 of tibia and basitarsus, except extreme apex, yellow. Wings hyaline; veins and stigma black. Head: Antenna 19-segmented, length $2 \mathrm{X}$ head width, with basal 1-4 flagellar segments swollen, tapering to narrow apex (Fig. 83); segments 5-9 about as long as broad, segments 10 to apex slightly longer than broad; scape:pedicel: $1^{\text {st }}$ antennomere as 1.0:0.7:0.9; pedicel $2 \mathrm{X}$ longer than broad measured on broadest side, strongly laterally flattened. Malar space linear; malar depression shallow, elongate. Genal carina indistinct; occipital carina present, width about one-third diameter of an ocellus. Lower interocular distance 0.9X eye height; inner margins of eyes parallel (Fig. 82). Labial palpus 4-segmented, apical segment not thickened. Maxillary palpus apparently 5-segmented, fifth segment indistinct. Ocellar area and frons reticulate; longitudinal carinae on interocellar area extending through clypeus (Fig. 82). Gena and vertex shining with few pits immediately posterior to hind ocelli; gena with 4-5 carinae on lower half. Thorax: Mesoscutum reticulate (Fig. 85). Axillae reticulate anteriorly, more punctate posteriorly; mesoscutellum shining, punctate, punctures denser on anterior and lateral margins, more sparsely punctate at center with shining interspaces separated by interspaces usually less than 
puncture diameters (Fig. 85). Propleuron shining, punctate ventrally, less so laterally and dorsally. Lateral pronotum shining, punctate to reticulate, reticulate on upper lateral corners (Fig. 84). Mesepisternum shining, punctate, punctures close together, separated by shining ridges mostly shorter than puncture diameters; mesepimeron smooth, shining, striate posteriorly (Fig. 84). Metapleuron finely reticulate, striate posteriorly. Hind wing with cells Rs, M, and A present. Fore- and midtarsal claws with inner tooth slightly more than half length of outer tooth; hind tarsal claw simple, much larger than fore- and midtarsal claws. Hind basitarsus 0.9X length of remaining tarsal segments combined. Abdomen: Tergites 1-8 finely microsculptured; inner third of basal plates smooth, shining, without sculpture; tergites 9 and 10 shinier than others; $9^{\text {th }}$ tergite with irregular transverse sculpture on apical half. Length of basal plates subequal to length of $2 \mathrm{nd}$ tergite. Sheath:valvifer 2:hind tibia as 1.0:0.9:0.7.

Male:

Length, 6.0-9.0 mm. Color: Antenna black with scape and pedicel reddish brown. Head black with continuous yellow stripe from middle of inner orbit through malar area through gena to posterior of vertex and two yellow spots on frons above antennal insertions. Thorax black lateral pronotal angles, spot on posterior half of axilla, longitudinal central stripe on lateral pronotum, upper half of mesepisternum, posterior third of mesepimeron, and posterior third of metapleuron yellow. Legs orange yellow. Abdomen black, mostly orange ventrally; lateral yellow spots on tergites 2 and 4-6, those on 4 and 5 largest. Head: Antenna 15-segmented, flagellum not quite as swollen basally as in female; segments longer than broad. Thorax: Hind wing with cells Rs or both Rs and $\mathrm{M}$ absent. All tarsal claws of similar size, each with long inner tooth, subequal in length to outer tooth and closely appressed to outer tooth.

Holotype: Female, labeled "Mt. Banahao, P.I., Baker" (USNM). Mt. Banahao is on Luzon, altitude $2120 \mathrm{~m}, 14^{\circ} 04^{\prime} 03^{\prime \prime N}, 121^{\circ} 29^{\prime} 33^{\prime} \mathrm{E}$.

Other specimens: 3 males labeled "Mt. Banahao, P.I., Baker" (USNM).

Etymology: Named for the type locality; a noun in apposition.

\section{Remarks:}

The males are associated by the same collection data and similarity of the antennae, rounded pronotum, and sculpturation of the head and thorax. In the female, all cells are present in the hind wing, the hind tarsal claws are simple and the fore- and midtarsal claws have a small inner tooth. In the male, one specimen has cell $\mathrm{M}$ absent and the others have both cells Rs and $\mathrm{M}$ absent in the hind wing, and all claws have an inner tooth.

\section{Obesaxiphyda borneensis (ROHWER), new combination}

(Figs 86-91)

Xiphydria heritierae borneensis ROHWER 1921:87.-HEDICKe 1938: 87.

Hyperxiphia borneensis: MAA 1949: 39, 165.-SMITH 1978: 106.

\section{Diagnosis:}

Head red; antenna, thorax, abdomen, and legs mostly black with lateral yellow stripe on pronotum and lateral yellow spot on $8^{\text {th }}$ tergite. Interantennal area reticulate. 


\section{Female:}

Length, $13.5 \mathrm{~mm}$. Color: Antenna black with scape red. Head red. Thorax black with yellow stripe on pronotum (Fig. 90). Abdomen black with a yellow elongate spot laterally on $8^{\text {th }}$ tergite. Legs black with basitarsi yellow. Wings hyaline, veins and stigma black. Head: Antenna 17-segmented; flagellum thickened at base, especially segments 1-5, tapering to narrow, acute apex; segments 4-9 about as long as broad (Fig. 87); length 2.0X head width; scape:pedicel" $1^{\text {st }}$ antennomere as 1.0:0.6:0.7; pedicel laterally flattened 2.0X longer than broad measured on broadest side. Malar space almost linear, malar depression shallow. Genal carina indistinct. Lower interocular distance 1.2X eye height; inner margins of eyes parallel (Fig. 86). Labial palpus 3-segmented; maxillary palpus 4-5 segmented. Ocellar area, frons, and interantennal area evenly reticulate; short longitudinal ridges on clypeus (Fig. 86). Gena and vertex smooth and shining. Thorax: Mesoscutum reticulate, with indication of transverse ridges on posterior half of middle lobe and more finely punctate on lateral areas of lateral lobes (Fig. 88). Axilla and mesoscutellum reticulate (Fig. 88). Propleuron shining, evenly densely punctate (Fig. 90). Pronotum anteroventrally shining with few scattered punctures, posterodorsally and upper lateral corners striate to reticulate; convex, rounded, without deep depression laterally (Fig. 90). Mesepisternum evenly punctate, separated by shining ridges less than puncture diameters; dorsoposteriorly with shining space, with punctures separated by interspaces almost equal to puncture diameters; mesepimeron shining, striate on posterior third (Fig. 90). Metapleuron finely reticulate, striate on posterior third (Fig. 90). Hind wing with cell Rs and M absent (Fig. 91). Fore- and midtarsal claws with long inner tooth; hind tarsal claw simple; fore tarsal claw smallest, inner tooth close to outer tooth. Hind basitarsus 1.1X length of remaining tarsal segments combined. Abdomen: Tergites 1 and 2 shining, punctured, 3-8 dull, microsculptured; 9 and 10 shining. Length of basal plates $1.5 \mathrm{X}$ length of $2^{\text {nd }}$ tergite. Sheath:valifer 2:hind tibia as 0.8:1.0:0.8.

Male: Unknown.

Type: Described from one female from "Sandakan, Borneo [Sabah, Malaysia]" Holotype labeled "Sandakan Borneo Baker," "o type No. 22589 U.S.N.M." (red), "Xiphydria heritierae borneensis Roh., Type + " (handwritten) (USNM). RoHwer stated that it differs from the typical form in having the upper margin of mesepisternum smooth and polished, the nervulus being interstitial with basal, and in the second and ninth tergites being entirely black. Xiphydria heritierae, the "typical" form, was described from "Sunderbans, Bengal, British India" where it was reared from "Sundri" - "Heritiera fomes Buch (= minor)."

Specimens examined: Other than the holotype, I have seen one female from peninsular Malaysia, labeled "Tamen Templer, Selangor, Peninsular Malaysia, 10-13, XII.2006, T. Mita leg." (NSMT).

Host: Unknown. The host of $O$. heritirae, Heritiera fomes Buck.Ham. (Sterculiaceae), also occurs on Borneo and could be the host of $O$. borneensis.

\section{Remarks:}

This species was originally a subspecies of $X$. heritierae, described from India. Females of both are similar, except Obesaxiphyda heritierae has a lateral yellow spot on the first tergite and one at the apex of the ninth tergite, has yellow spots on the pronotum, and cells RS, M, and A in the hind wing are present.

The male of $O$. borneensis is not known, but males are associated with $O$. heritierae. These males differ from the female by the following: each tarsal claw with long inner tooth, subequal in length 
to outer tooth and closely appressed to outer tooth; hind wing with cells Rs and M present or absent (even in same specimen), and anal cell of hind wing present or absent. The antenna is not quite as thickened as in the female, but the pedicel is similarly flattened and about 1.5X longer than broad on its broadest side, and all antennomeres are mostly about as long or a little longer than broad.

The female from Selangor is identical to the holotype except the antennae are 15-segmented.

\section{Hyperxiphia MAA}

Hyperxiphia MAA 1949: 23, 38. 165. Type species: Hyperxiphia ungulivaria MAA. Original designation.

Palpixiphia MaA 1949: 23, 31, 165. Type species: Xiphydria formosana Enslin. Original designation. New synonymy.

\section{Description:}

Antenna filiform, 16-17 segmented; pedicel 2X or more longer than broad; eyes large, lower interocular distance about equal to eye height, inner markings of eyes subparallel, head behind eyes in lateral view short (Figs 92, 93, 96, 100), head in dorsal view sharply narrowing behind eyes; malar space narrow, less than half diameter on an ocellus; genal carina present, extending to top of eye, sometimes not distinct; occipital carina distinct, narrow, less than half diameter of an ocellus, uniformly broad, not enlarged laterally; labial palpus 3-4 segmented; maxillary palpus 4-5 segmented, much narrower than labial palpus and less than half length of labial palpus; gena and vertex smooth and shining; frons densely sculptured, sculpturation usually reticulate, without distinct longitudinal carinae. Pronotum deeply concave laterally; mesonotum densely sculptured; mesepisternum densely sculptured or shining with large punctures separated by flat interspaces. All tarsal claws of both sexes with inner tooth; female with hind claw much larger than fore- and midclaws. Forewing: Costal cell narrow, width less than $2 \mathrm{X}$ width of costa. Hind wing: Cells Rs, $\mathrm{M}$, and A present; 1A straight, 2A sharply curved up at apex meeting 1A to form cell.

\section{Remarks:}

This genus is characterized by the presence of an inner tooth on all tarsal claws in the female, presence of a distinct genal carina, reticulate frons, without longitudinally directed sculpture, and complete wing venation with all veins and cells present. The male is known only for H. flavicornis.

MAA (1949) distinguished Palpixiphia from Hyperxiphia by the apically "bifurcate" tarsal claws, apical segment of the maxillary palpus very short, about half as long as the third or fourth segments, relative lengths of the segments of the labial palpus, and the apical segment of the labial palpus originating preapically on the third. Among material I have examined, including males of Xiphydria formosana EnsLin (Hyperxiphia formosana (Enslin), n. comb.), the type species of Palpixiphia, I see various combinations of the shapes of the maxillary and labial palpi and tarsal claws. Characters of some species agree with Palpixiphia except for the preapical position of the apical segment of the labial palpus. As a consequence, I cannot see a valid distinction between the genera, and here combine them.

This genus occurs from southern Japan throughout southeastern Asia to the Philippines and Indonesia. I include only three species in the present study. Two species have the apical antennal segments white. 


\section{Key to Species (Females)}

1. Antennal flagellum all or mostly white; mesepisternum with upper third or streak on upper margin yellow (Figs 95, 100); mesoscutum reticulate (Figs 98, 103) ......................... 2

Antenna black; mesepisternum black (Fig. 95); mesoscutum with fine transverse carinae at center (Fig. 94) (Indonesia: Java) cyanea (MocsÁrY)

2. Antennal flagellum white; head broadly white on inner orbits (Fig. 96); axilla white, metanotum yellow (Fig. 98); transverse band of longitudinal carinae above ocelli (Fig. 96) (Malaysia: Sabah) flavicornis (ROHWER)

- $\quad$ Apical 8-9 flagellar segment white; head black with white spot on upper inner orbit, lower orbit, and gena (Fig. 100); pronotum and mesonotum black (Fig. 103); head smooth and shining behind ocelli (Fig. 100) (Indonesia: Sulawesi) sulawesi, n. sp.

\section{Hyperxiphia cyanea (MoCSÁRY)}

(Figs 92-95)

Xiphydria cyanea Mocsáry 1891: 158.-Dalla Torre 1894: 395.-Konow 1897: 302, 307, 311.-Konow

1905a: 4.-Konow 1905b: 43, 54.-Forsius 1933: 170.-Hedicke 1938: 6.

Hyperxiphia cyanea: MAA 1949: 40, 165.-Sмітн 1978:106.

\section{Diagnosis:}

With slight metallic luster. Antenna black. Mesepisternum, mesonotum, and metanotum black. Mesoscutum with fine transverse carinae.

\section{Description:}

Length, $10.5 \mathrm{~mm}$. Color: Antenna black. Black with metallic blue luster. Head black with continuous narrow yellow stripe from middle of inner orbit through malar and gena to top of eye (Figs 92, 93). Thorax black with small yellow spot on posterior margin of lateral pronotum and small yellow stripe on extreme upper edge of mesepisternum (Fig. 95). Legs black, tibiae and basitarsi white. Abdomen black with lateral yellow spots on tergites 2 and 8 , one on $8^{\text {th }}$ largest (Fig. 92). Wings hyaline, veins and stigma black. Head: Antenna 16-17 segmented (Fig. 92), length 2.0X head width; scape:pedicel: $1^{\text {st }}$ antennomere as 1.0:0.5:0.8; pedicel 2.0X longer than broad. Malar space narrow, about half diameter of an ocellus. Genal carina indistinct; occipital carina distinct. Lower interocular distance 1.1X eye height; inner margins of eyes parallel (Fig. 93). Labial palpus appears 3-segmented with apparent sensory pit apically on apical segment. Maxillary palpus 5-segmented (difficult to see). Frons with longitudinal carinae from near upper margin of frons extending through interantennal area onto clypeus, interspaces shining, ocellar area and frons just below ocelli shining with scattered punctures (Fig. 93). Gena and vertex shining with scattered punctures. Thorax: Mesoscutal middle lobe reticulate, smoother on anterior third, posterior two-thirds with indistinct, irregular transverse carinae; mesoscutal lateral lobes reticulate, scrobiculate on inner margins (Fig. 94). Axilla and mesoscutellum reticulate (Fig. 94). Propleuron shining, punctate (Fig. 95). Pronotum mostly smooth and shining, few narrow ridges in diagonal concavity, and reticulate dorsally and on upper lateral corners (Fig. 95). Mesepisternum shining, with large punctures separated by narrow ridges, dorsoposterior margin shining, without sculpture; mesepimeron shining, finely striate posteriorly (Fig. 95). Metapleuron shining, reticulate (Fig. 95). Each tarsal claw with inner tooth; foreclaw with inner tooth close to 
and more than half length of outer tooth, inner tooth of middle and hind claws near center of claws and shorter than half length of outer tooth; claws increasing in size with hind claw largest. Hind basitarsus $0.8 \mathrm{X}$ length of remaining tarsal segments combined. Abdomen: Dull, microsculptured; medial third of basal plates, apical parts of tergites 2-4, and apical tergite shining, lacking surface microsculpture. Length of basal plates subequal to length of 2nd tergite. Sheath:valvifer 2:hind tibia as 0.8:1.0:1.2.

Type: Female, described from "Java." A syntype (HNHM) is labeled "Java", "Mocsáry ajánd", "Typus Xiphydria cyanea Mocs 1891." Mocsáry stated "female" but the number of specimens was not indicated. I am designating this specimen a lectotype to ensure nomenclatural stability.

\section{Remarks:}

This species has a distinct metallic-blue luster, more so than other species treated here. Otherwise, it can be distinguished from other Hyperxiphia species treated here by the black antennae, the almost entirely black head, thorax, and abdomen, and the large, almost confluent punctures of the mesepisternum.

Forsius (1933) questionably recorded a female from "North borneo: Sumawang, near Sandakan [Sabah, Malaysia], 15 ${ }^{\text {th }}$ July, 1927, C. B. Kloss and H. M. Pendleburry," Examination of the specimen is needed to verify this record.

\section{Hyperxiphia flavicornis (ROHWER), new combination}

(Figs 96-99)

Xiphydria flavicornis Rohwer 1921: 87.-Forsius 1933: 170.-Hedicke 1938: 7.

Palpixiphia flavicornis: MAA 1949: 33, 165.-Sмітн 1978:

\section{Diagnosis:}

Antennal flagellum white. Inner orbits broadly yellow; upper third of mesepisternum yellow; metanotum yellow. Transverse band of longitudinal carinae above ocelli. Mesepisternum shining with scattered pits. Basal abdominal tergites yellow.

\section{Female:}

Length, $12.0 \mathrm{~mm}$. Color: Antenna white. Head yellow with black transverse stripe on vertex extending to top inner margin of each eye; a broad stripe extending through ocellli to center of frons, from center of frons, black divided into three small stripes, one medially to interantennal area and two to dorsum of each antennal insertion; and narrow median stripe on vertex from interocellar area to occiput (Fig. 96). Thorax black with lateral corner of pronotum, upper third of mesepisternum, axilla, two spots on mesoscutellum, and metanotum yellow. Abdomen mostly yellow basally, black apically; segment 1 yellow with inner margin of basal plates black; segments 2 and 3 yellow with narrow posterior margin of tergites black; segment 4 with anterior half yellow, posterior half black; segments 5 and 6 black with narrow anterior margin yellow; tergites 7 and 8 with large lateral yellow spots; tergite 9 black with apex yellow. Legs yellow. Wings hyaline, veins and stigma black. Head: Antenna 17-segmented; length $1.4 \mathrm{X}$ head width; scape:pedicel: $1^{\text {st }}$ antennomere as 1.0:0.5:0.7; pedicel 2.4 X longer than broad. Malar space narrow, equal to about one-quarter diameter of an ocellus. Genal carina distinct to top of eye; occipital carina large, equal to half or more diameter of an ocellus. Lower interocular distance 1.1X eye height; inner margins of eyes parallel (Fig. 96). Labial palpus 4-segmented, apical segment slightly enlarged; maxillary palpus 5-segmented. Maxillary palpus, segments uncertain (difficult to see), apical two 
segments short. Ocellar area, frons, and interantennal area reticulate, shining (Fig. 96). Gena and vertex smooth and shining, transverse band of longitudinal carinae between eyes posterior to hind ocelli. Thorax: Mesoscutum, except for median shining spot anteriorly, axilla, and mesoscutellum reticulate, shining (Figs 98, 99). Propleuron shining, punctate (Fig. 97). Lateral pronotum shining, mostly without sculpture, center with several short carinae and upper lateral lobes finely reticulate (Fig. 99). Mesepisternum shining with large scattered punctures mostly separated by flat interspaces about equal to diameter of a puncture; mesepimeron shining with narrow band of striae on posterior margin (Fig. 97). Metapleuron finely reticulate (Fig. 97). All tarsal claws with long inner tooth; inner tooth of foreclaw about three-quarters length of outer tooth and close to outer tooth; inner tooth of middle and hind legs about half length of outer tooth and located near center of claws; foreclaw more slender than larger middle and hind claws. Hind basitarsus slightly longer than remaining tarsal segments combined. Abdomen: Shining, slightly dulled with microsculpture. Length of basal plates $1.3 \mathrm{X}$ length of $2^{\text {nd }}$ tergite. Sheath:valvifer:hind tibia as 0.8:1.0:0.8.

Male: Length, $7.2 \mathrm{~mm}$. Antenna brownish. Head yellow with ocellar area and area immediately posterior to ocelli black; frons brownish. Thorax yellow with brownish on lateral pronotum and on mesoscutal middle and lateral lobes. Abdomen brown above, lateral areas of tergites and sternites yellow. All tarsal claws of similar size. Length of basal plates $1.7 \mathrm{X}$ length of $2^{\text {nd }}$ tergite.

Types: Rohwer (1921) described this species “... from one female (type) and one male (allotype) collected by C. F. Baker." from "Sandakan, Borneo [Sabah, Malaysia]". The holotype is labeled "Sandakan Borneo Baker," "type No. 22379 U.S.N.M." (red), "Xiphydria flavicornis Roh, type" (handwritten) (USNM). The male allotype (USNM) has the same data except "Allotype No. 22379 U.S.N.M.” and allotype instead of type written on the determination label.

Other specimens: North Borneo: Bettotan, near Sandakan, 14-21 August, 1927, C. B. KLoss and H. M. Pendlebury (3 m, TURKU).

\section{Remarks:}

The male (paratype) described by RoHwer is pale yellowish brown, has all claws bifid, and has both cells in the hind wing. This species was placed in Palpixiphia by MAa (1949) but I here transfer it to Hyperxiphia.

Forsius (1933) recorded 8 males from the North Borneo locality above. I examined three of the males from the Forsius collection (TURKU) and have determined that they are conspecific with male RoHwer (1921) described.

The mostly white antennal flagellum, white inner orbits, and rather smooth and shining mesepisternum with only widely scattered pits distinguish this species.

\section{Hyperxiphia sulawesi SMITH, new species}

(Figs 100-104)

\section{Diagnosis:}

Apical antennomeres of antenna white. Head black with small spot on upper inner orbit, two spots on frons, and malar area yellow. Basal abdominal segments black with lateral yellow spot on tergites 2. 7. and 8. Mesepisternum with narrow white stripe on upper margin. Mesonotum and metanotum black. Head shining behind ocelli. Mesepisternum evenly reticulate. 


\section{Female:}

Length, $12.0 \mathrm{~mm}$. Color: Antenna black with apical 9 flagellar segments white. Head black with white spot on upper inner orbit, two small spots on frons, and stripe on lower outer orbit through malar area and extending onto outer orbit to about midlength of eye (Fig. 100). Thorax black with spot on lateral pronotal corners and stripe on upper margin of mesepisternum white (Fig. 102). Legs black with basal half of tibiae and basitarsi white. Abdomen black with lateral white spot on $2^{\text {nd }}$ tergite; large rectangular marks laterally on tergites 7 and 8 , and lateral yellow spots at apex of $9^{\text {th }}$ tergite. Head: Antenna 17-segmented; length 1.5X head width; scape:pedicel: $1^{\text {st }}$ antennomere as 1.0:0.5:0.6; pedicel more than $2 \mathrm{X}$ longer than broad. Malar space narrow, about half diameter of an ocellus, carina below eye in malar area. Genal carina distinct only on lower half of eye, without associated ridges. Lower interocular distance 1.1X eye height; inner margins of eyes parallel (Fig. 100). Labial palpus 4-segmented, apical segment slightly enlarged enlarged (Fig. 92). Maxillary palpus apparently 4-segmented. Ocellar area, frons and interantennal area reticulate, several arclike carinae dorsal to antennal insertions (Fig. 101). Gena and vertex smooth and very shining, without sculpture, vertex shining to hind ocelli. Thorax: Mesonotum shining, reticulate; mesoscutellum smoother and shining on extreme lateral and posterior sides; narrowly scrobiculate in notauli (Fig. 103) Propleuron shining, punctate (Fig. 102). Pronotum shining, with several curved carinae at center and dorsolateral margins reticulate (Fig. 102). Mesepisternum reticulate with dorsoposterior margin smooth and shining; mesepimeron smooth and shining, few striae on extreme posterior margin (Fig. 102). Metapleuron reticulate (Fig. 102). Fore tarsal claw with small inner tooth near center, less than half length of outer tooth; middle and hind tarsal claws with small tooth at center, about half length of outer tooth (Fig. 104); middle and hind tarsal claws much larger than fore tarsal claw. Hind basitarsus $0.8 \mathrm{X}$ length of remaining tarsal segments combined. Abdomen: Dull with fine microsculpture, more densely punctate on tergite 1 . Length of basal plates $1.4 \mathrm{X}$ length of $2^{\text {nd }}$ tergite. Sheath:valvifer 2 :hind tibia as $0.7: 1.0: 1.4$.

Holotype: Female, labeled "Indonesia: SE Sulawesi nr Sanggona, Base Camp, Gn. Watuwila, Mal. trap 2, c 200 m, 10-15.x.1989, C. v. Achterberg, RMNH '89” (RMNH).

Etymology: The species name is for the type locality, a noun in apposition.

\section{Remarks:}

The white antennal flagellum, white spot on the upper inner orbits, black axillae, only the upper margin of the mesepisternum white, and large confluent pits of the mesepisternum will separate this species.

\section{Lataxiphyda SMITH, new genus}

Type species: Xiphydria pyrura RoHwer.

\section{Description:}

Antenna 14-18 segmented, swollen and tapering to apex with segments beyond 3 about as long as broad or broader than long in female (Figs 109, 112); filiform, with segments longer than broad in male; pedicel short, as long as or slightly longer than broad. Eyes small, oval, lower interocular distance greater than eye height, eyes in lateral view removed from posterior margin of head (Figs 105, 106, 111, 112, 116), in dorsal view long behind eyes with length behind eyes equal to eye length; malar space less than half diameter of an ocellus; genal carina distinct to top of eye; occipital carina distinct and broad, about half diameter of an ocellus; labial palpus 
4-segmented; maxillary palpus 5-segmented, less than half diameter of labial palpus and less than half length of labial palpus; gena and vertex shining, smooth or punctured; frons densely sculptured or shining with sparse sculpture. Pronotum deeply concave laterally; mesonotum and mesepisternum densely sculptured. Each tarsal claw with inner tooth in both sexes. Forewing: Costal cell very broad, 5-6X diameter of costa (Figs 110, 120). Hind wing: Cells Rs, M, and A present; $1 \mathrm{~A}$ and $2 \mathrm{~A}$ evenly curved toward apex meeting at center to form rounded apex of anal cell (Figs 110, 121).

Etymology: From the Latin latus, broad, referring the broad costal cell of the forewing. Gender: feminine.

\section{Remarks:}

Distinctive characters are the very broad costal cell of the forewing, as well as the short antennae, short pedicel, small eyes, elongated head length behind eyes, and rounded apex of the anal cell of the hind wing. Species are known only from the Philippines and insular and peninsular Malaysia.

\section{Key to Species}

1. Female 2

Male 3

2. Gena and vertex densely punctate (Fig. 106); antenna 14-segmented, only slightly swollen at center, with segments 4 to apex about as broad as long (Fig. 109); mesoscutal middle lobe V-shaped, narrowly scrobiculate laterally and with narrow median scrobiculate line (Fig. 108) erythropus (CAMERON)

- Gena and vertex mostly smooth with few punctures (Figs 111, 112); antenna 17 to 18-segmented, swollen at center, with segments 4 to apex broader than long (Figs 111, 112); mesoscutal middle lobe U-shaped, broadly scrobiculate laterally and reticulate at center, without median scrobiculate median line (Fig. 114) paraerythropus, n. sp.

3. Head shining, frons and gena mostly with few carinae or striae (Figs 115, 116); front of head rounded, not distinctly depressed (Fig. 116); inner tooth of tarsal claws subequal to outer tooth and closely appressed to outer tooth (Fig. 119) pyrura (ROHWER)

- Head with frons and gena punctate to reticulate (Figs 105, 106, 111, 112); head above ocelli depressed in lateral view (Figs 106, 112); inner tooth of tarsal claws near center or base of claw and shorter than outer tooth (similar to Fig. 104)

4. Gena and vertex densely punctate (Fig. 106); antenna 14-segmented; mesoscutal middle lobe V-shaped, narrowly scrobiculate laterally and with narrow median scrobiculate line (Fig. 108) erythropus (CAMERON)

- Gena and vertex mostly smooth with few punctures (Figs 111, 112); antenna 17 to 18 -segmented; mesoscutal middle lobe U-shaped, broadly scrobiculate laterally and reticulate at center, without median scrobiculate median line (Fig. 114) paraerythropus, n. sp. 


\section{Lataxiphyda erythropus (CAMERON), new combination}

(Figs 105-110)

Xiphydria erythropus Cameron 1903: 89.-Konow 1905a: 4.-Konow 1905b: 197.-Forsius 1933: 170 (syn.: melanopus Cameron).-Hedicke 1938: 7.

Hyperxiphia erythropus: MAA 1949: 39, 165.-Sмітн 1978: 106.

Xiphydria melanopus Cameron 1903: 90.-Konow 1905a: 4.-Konow 1905b: 198.

\section{Diagnosis:}

Gena and lateral and frontal areas of vertex densely punctured; frons densely reticulate. Antenna 14-segmented.

\section{Female:}

Length, $17.0 \mathrm{~mm}$. Color: Black. Wings moderately, uniformly infuscated, veins and stigma black. Head: Antenna 14-segmented, slightly swollen near center, tapering to apex, with segments beyond third about as broad as long (Fig. 109); length $1.2 \mathrm{X}$ head width; scape:pedicel: $1^{\text {st }}$ antennomere as 1.0:0.3:0.8; pedicel 1.3X longer than broad. Malar space broad, about 3X diameter of an ocellus; carina below eye in malar area. Genal carina distinct to top of eye. Occipital carina distinct, about one-third diameter of an ocellus. Lower interocular distance $1.4 \mathrm{X}$ eye height; inner margins of eyes subparallel (Fig. 105). Labial palpus 4-segmented; maxillary palpus 5-segmented. Ocellar area and frons through clypeus densely reticulate (Fig. 105). Gena reticulate to punctate; vertex shining, reticulate behind ocelli, at center and posteriorly smooth and shining with few punctures. Head depressed at level posterior to ocelli (Fig. 106). Thorax: Mesonotum densely reticulate; mesoscutal middle lobe $\mathrm{V}$-shaped with narrow scrobiculate medial line and narrowly scrobiculate laterally, separations of axillae and mesoscutellum narrowly scrobiculate (Fig. 108). Propleuron shining, densely punctate, punctures separated by flat interspaces about equal to puncture diameters (Fig. 106). Lateral pronotum shining, with curved carinae on ventroanterior half and reticulate on dorsoposterior half and on lateral corners (Fig. 106). Mesepisternum, mesepimeron, and metapleuron reticulate (Fig. 107). Each tarsal claw with inner tooth; hind tarsal claw largest, with inner tooth small, less than one-third length of outer tooth and located near base of claw; midtarsal claw slightly smaller than hind tarsal claw with inner tooth more near center of claw and about half length of outer tooth; fore tarsal claw smallest with inner tooth located near center of claw and slightly more than half length of outer tooth. Hind basitarsus $0.8 \mathrm{X}$ length of remaining tarsal segments combined. Abdomen: Shining; anterior edges of tergites 1-5 dull, microsculptured, tergite 1 dullest, more punctate than tergites 2-5; tergites rounded, depressed anteriorly, convex posteriorly with depressed area more microsculptured than convex area. Length of basal plates subequal to length of $2^{\text {nd }}$ tergite. Sheath:valvifer2:hind tibia as 0.7:1.0:1.2.

Male: Length, $15.0 \mathrm{~mm}$. Similar to female except for following. Color: Black with scape, pedicel, and legs dark red. Head: Antenna 14-segmented, slender and filiform, with segments 3 to apex $2 \mathrm{X}$ or more longer than broad (Fig. 106); pedicel about as long as broad. Gena and vertex slightly more densely reticulate and punctate than in female. Thorax: Each tarsal claw with inner tooth, inner tooth slightly shorter than outer tooth and near center of claw.

Types: A male syntype of X. erythropus is labeled "Type" (red-bordered round label), "B.M. Type Hym. 1.21," "Cameron coll. 1903-121," "Xiphydria erythropus Cam. Type. Matang, $3600 \mathrm{ft}$. Borneo" (handwritten) (BMNH). The right antennal flagellum is missing and the left forewing is glued on cardboard below the specimen. The original description stated "Matang 3600 feet." and "male" without indicating the number of specimens. I am designating this specimen a lectotype to ensure nomenclatural stability. 
A female syntype of Xiphydria melanopus is labeled "Type" (red-bordered round label), "B.M. type Hym. 1.20," "Cameron Coll. 1905-121," "Xiphydria melanopus Cam., type, Matang, Borneo" (handwritten) (BMNH). The locality was given as "Matang" in the original description. Matang is in Sarawak, Malaysia. The number of specimens was not indicated; thus, I am designating this specimen a lectotype to ensure nomenclatural stability.

\section{Remarks:}

Forsius (1933) recorded three females and one male from the "Malay Peninsula, Selangor, Bukit Kutu." These are described as L. paraerythropus below.

I have little doubt that $X$. erythropus and $X$. melanopus are opposite sexes of the same species as suggested by Forsius (1933). The slight differences in sculpturation and color as noted by Cameron can be attributed to sexual dimorphism. MAA (1949) placed this species in Hyperxiphia and followed Forsius' synonymy.

\section{Lataxiphyda paraerythropus SMITH, new species}

(Figs 111-114)

Xiphydria erythropus: Fonsius 1933: 170.

\section{Diagnosis:}

Gena and lateral and frontal areas of vertex sparsely punctured; antenna 17 to 18 -segmented; mesoscutal middle lobe U-shaped, broadly scrobiculate at sides, without median longitudinal scrobiculate line.

\section{Female:}

Length $16.0 \mathrm{~mm}$. Color: Black. Wings moderately, uniformly infuscated; veins and stigma black. Head: Antenna 17- 18 segmented, swollen at base, tapering to apex, with segments beyond third broader than long (Figs 111, 112); length $1.1 \mathrm{X}$ head width; Scape:pedicel: $1^{\text {st }}$ antennomere as 1.0:0.4:0.8; pedicel 1.2X longer than broad. Malar space about $3 \mathrm{X}$ diameter of front ocellus; carina below eye in malar area. Genal carina distinct to top of eye. Occipital carina distinct, about one-third diameter of an ocellus. Lower interocular distance $1.5 \mathrm{X}$ eye height, inner margins of eyes subparallel (Fig. 111). Labial palpus 4-segmented; maxillary palpus 5-segmented. Ocellar area and frons thogu clypeus reticulate (Fig. 111). Gena and vertex mostly smooth, shining, with only scattered punctures. Head depressed at level posterior to ocelli (Fig. 112). Thorax: Mesonotum reticulate with lateral margins of mesoscutal middle lobe broadly scrobiculate; mesoscutal middle lobe U-shaped (Fig. 114); propleuron shining, densely punctate, punctures separated by flat interspaces about equal to puncture diameters (Fig. 112). Lateral pronotum shining, with few punctures anteroventrally, reticulate dorsoposteriorly (Fig. 113). Mesepisternum densely punctate, punctures separated by narrow shining interspaces less than puncture diameters; mesepimeron with few punctures, scrobiculate posteriorly; metapleuron and propodeum punctate, similar to mesepisternum (Fig. 113). Each tarsal claw with inner tooth; hind tarsal claw largest, with inner tooth small, less than one-third length of outer tooth and located near base of claw; midtarsal claw slightly smaller than hind tarsal claw with inner tooth more near center of claw and about half length of outer tooth; fore tarsal claw smallest, with inner tooth located near center of claw and slightly more than half length of outer tooth. Hind basitarsus $0.8 \mathrm{X}$ length of remaining tarsal segments combined. Abdomen: Shining; anterior edges of tergites 1-5 dull, microsculptured, tergite 1 dullest, more punctate than tergites 2-5; tergites rounded, depressed anteriorly, convex 
posteriorly with depressed area more microsculptured than convex area. Length of basal plates subequal to length of $2^{\text {nd }}$ tergite. Sheath:valvifer2:hind tibia as 0.7:1.0:1.2.

Male: Length $14.0 \mathrm{~mm}$. Similar to female except for following: Color: Black with scape, pedicel and legs dark red. Head: Antenna 14-segmented, slender and filiform, with segment 3 to apex 2X or more longer than broad; pedicel about as long as broad. Gena and vertex slightly more densely reticulate and punctate than in female. Thorax: Each tarsal claw with inner tooth, inner tooth slightly shorter than outer tooth and near center of claw.

Types: Holotype: Female, labeled "Malay Penin: Selangor, Bukit Kutu, 3300-3500 ft., 18-23-1931, H. M. Pendlebury” (TURKU). Paratype: Same data as holotype except 14-3-1931, 3500 ft. (1 o`, TURKU).

Etymology: Para plus erythropus, indicating the species is near L. erythropus.

\section{Remarks:}

Forsius (1933) recorded three females and one male of $X$. erythropus from the "Malay Peninsula, Selangor, Bukit Kutu, 3,300-3,500 ft., 14 March, 1931 and one male from the same locality, collected 16 April, 1926 by H. M. Pendlebury." I examined one female and one male from the Forsius collection (TURKU). They belong in Lataxiphyda and are similar to L. erythropus in general habitus, the presence of a depression above the ocelli, and color, but they are not the same species. Those from Selangor have different head and thorax sculpture, and the female antenna is much more enlarged and has 17-18 segments.

This species was recorded as $X$. erythropus by Forsius (1933), but examination of two of the specimens Forisus examined show they are different. The two can be separated by characters in the key. Though outside of the region treated in this paper, I include it because it is the only other species known in the genus and to clarify Forsius' determination.

\section{Lataxiphyda pyrura (ROHWER), new combination}

(Figs 115-121)

Xiphydria pyrura RoHwer 1921: 88.-Hedicke 1938: 12.

Palpixiphia pyrura: MaA 1949: 31, 165.-BaLtazar 1966: 14.-Sмith 1978: 110.

\section{Diagnosis:}

Wings darkly infuscated. Frons and gena shining, with some carinae and reticulations on frons above and between antennae and only carinae on gena. Inner tooth of tarsal claws long, close to and appressed to outer tooth.

Female: Unknown.

Male:

Length, $14.0 \mathrm{~mm}$. Color: Head and thorax black. Abdomen black with sternites and segments 7 to apex orange. Legs with coxae and femora black, tibiae and tarsi dark reddish brown. Wings darkly, uniformly infuscated; veins and stigma black. Head: Antenna 14-segmented; length 1.3X head width; scape:pedicel: $1^{\text {st }}$ antennomere as 1.0:0.4:0.5; pedicel 1.3X longer than broad. Malar space distinct, narrow, about one-third diameter of an ocellus. Occipital and genal carinae distinct, genal carina distinct to top of eye (Fig. 116). Lower interocular distance 1.2X eye height; inner margins of eyes parallel (Fig. 115). Labial palpus 4-segmented, apical segment not enlarged; maxillary 
palpus 5-segmented, segment 2 slightly longer than apical three segments, apical three segments subequal in length. Head not so deeply depressed above ocelli, more rounded in lateral view (Fig. 116). Frons shining, with scattered punctures below ocelli and reticulations and longitudinal carinae from center of frons extending onto interantennal area and clypeus (Fig. 115). Gena and vertex smooth and shining with scattered punctures and several longitudinal carinae on gena. Thorax: Mesonotum densely and evenly reticulate (Fig. 118). Propleuron shining, evenly punctate with interspaces about equal to puncture diameters. Lateral pronotum shining, scattered small punctures on anteroventral half, reticulate on posterodorsal half and upper lateral corners (Fig. 117). Mesepisternum evenly, densely reticulate; mesepimeron shining, finely punctate, with narrow row of striae on posterior margin (Fig. 117). Metapleuron reticulate (Fig. 117). Each tarsal claw with inner tooth, inner tooth of each nearly as long as outer tooth and close to and appressed to outer tooth (Fig. 119). Hind basitarsus 0.8X length of remaining tarsal segments combined. Hind wing with cells Rs and M present (Fig. 121). Abdomen: Tergites 1-4 densely punctate, sculpture less dense on medial margins, tergites 5 and 6 less densely punctate than 1-4, tergites 7 to apex shining. Tergites 7 to apex rounded, depressed anteriorly, convex posteriorly; anterior depression with dull microsculpture. Length of basal plates subequal to length of $2^{\text {nd }}$ tergite.

Types: Holotype male, described from "Mount Makiling, Luzon, Philippine Islands. One male collected by C. F. Baker. Also one male, collected March to June, 1911, by C. V. Piper, at Lamao, Luzon, Philippine Islands." The holotype is labeled "Mt. Makiling, Luzon, P.I.," "male type no. 22380 U.S.N.M." (red), "Xiphydria pyrura Roh, type male" (handwritten) (USNM). The paratype is labeled "Lamao, Luzon, III-VI-11, P.I.," "C.V. Piper, Collector," "Paratype No. 22380 U.S.N.M.” (red) (USNM). There is no determination label.

\section{Remarks:}

The smooth and shining genae and vertex, appressed teeth of the tarsal claws, lack of a deep depressed area posterior to the ocelli, and black abdomen with the apex orange are distinctive for this species. Although there are probably sexual differences in the tarsal claws, color, and perhaps some sculpturation, the female should not be difficult to associate with this species. MAA (1949) placed this species in Palpixiphia based on the original designation.

\section{Unassociated Male of Xiphydriidae}

One male is labeled "Philippines: Mountain Prov., Abatan, Buguias, $60 \mathrm{~km} \mathrm{S.} \mathrm{of} \mathrm{Bontoc,}$ 1800-2000 m, 31.V.-1.VI-64, H. M. Torrevillas Collector, Bishop” (BPBM). The locality is on the island of Luzon. I am unable to associate this with the species or genera treated in this paper. This specimen has all claws bifid, the inner tooth almost as long as the outer tooth, the pronotum deeply excavated laterally, both the frons and genae with longitudinal carinae, and the color is mostly black with pale areas on the head and thorax. It is like Indoxiphia and Hyperxiphia, possibly most similar to Hyperxiphia flavicornis from Sandakan, Sabah, Malaysia. I prefer not to describe an unassociated male, especially since generic placement is questionable.

\section{Acknowledgments}

I appreciate the help of the following people for lending specimens: D. WAHL, American Entomological Institute, Gainesville, Florida, USA; G. NishidA, Bernice P. Bishop Museum, Honolulu, Hawaii, U.S.A.; K. van Achterberg, Leiden, The Netherlands; A. Taeger and S. M. Blank, Deutsches Entomologisches Institut, Müncheberg, Germany; K. Goodger, The Natural History Museum, London; H. Goulet, 
Canadian National Collection of Insects, Ottawa; A. Shinohara, National Science Museum (Natural History), Tokyo, Japan; J. E. Hogan, Hope Entomological Collections, Oxford University Museum of Natural History, Oxford, U.K.; P. Tripotin, Okcheon-gun, South Korea; L. Zombori, Hungarian Natural History Museum, Budapest; D. C. Darling, Royal Ontario Museum, Toronto, Ontario, Canada; L. Kimsey and S. Heydon, Univeresity of California, Davis; N. M. Schiff, U. S. Forest Service, Stoneville, Mississippi, U.S.A. Thanks also for the help of LuA Hur KHEng, Raffles Museum of Biodiversity Research, National University of Singapore, and JukKa Vauras, Biological Collections of Åbo Akademi University, Turku, Finland, for attempting to find some of the specimens reported by Forsius (1933). Comments and suggestions by the following reviewers are appreciated: S. M. BLANK, Deutsches Entomologisches Institut, and N. J. Vandenberg and T. J. Henry, Systematic Entomology Laboratory, U. S. Department of Agriculture, Washington, D.C.

\section{Literature Cited}

Baltazar, C. R. 1966: A catalogue of Philippine Hymenoptera (with a bibliography 1758-1963). - Pacific Insects Monograph 8: 488 pp.

Basibuyuk, H. H. \& Quicke, D. L. J. 1995: Morphology of the antenna cleaner in the Hymenoptera with particular reference to non-aculeate families (Insecta). - Zoologica Scripta 24: 157-177.

Benson, R. B. 1935: A collection of sawflies (Hymenoptera Symphyta) from Java. - Zoologische Mededeelingen 18: 167-180.

Benson, R. B. 1954: Classification of the Xiphydriidae (Hymenoptera). - Transactions of the Royal Entomological Society of London 105: 151-162.

Cameron, P. 1903: Descriptions of new genera and species of Hymenoptera taken by Mr. Robert Shelford at Sarawak, Borneo. - Journal of the Straits Branch of the Royal Asiatic Society 39: 89-181.

Dalla Torre, C. G. 1891: Catalogus Hymenopterorum. V. 1. Tenthredinidae incl. Uroceridae (Phyllophaga \& Xylophaga). - Lipsiae: 459 pp.

Forsius, R. 1933: Notes on a collection of Malaysian Tenthredinoidea (Hym.). - Bulletin of the Raffles Museum 8: 169-193.

Hedicke, H. 1938: Xiphydriidae. - In: Hedicke, H. (ed.): Hymenopterorum Catalogus, ars 7, - Dr. W. Junk, 's-Gravenhague: 17 pp.

Huber, J. T. \& Sharkey, M. J. 1993: Chapter 3. Structure, pp. 13-59. - In: Goulet, H. \& Huber, J. T. (eds): Hymenoptera of the World: An Identification Guide to Families. - Research Branch, Agriculture Canada, Ottawa, Publication 1894/E: 668 pp.

Jansen, E. 1987: Die europäischen Arten der Gattung Konowia Brauns (Hymenoptera: Xiphydriidae). - Stuttgarter Beiträge zur Naturkunde, Serie A (Biologie) 4: 1-12.

Jennings, J. T.; Austin, A. D. \& Schiff, N. M. 2007: Rhysacelphala novacaledonica sp. nov. (Hymenoptera: Xiphydriidae), the first xiphydriid woodwasp from New Caledonia. - Zootaxa 1516: 23-30.

Konow, F. 1897: Ueber Holzwespen. - Entomologische Nachrichten 23: 297-311.

Konow, F. 1905a: Hymenoptera, family Siricidae. - In: Wytsman, P. (ed.): Genera Insectorum, Fasc. 28. - Bruxelles: 14 pp.

Konow, F. 1905b: 2. Fam. Siricidae Knw. - Zeitschrift für Systematische Hymenopterologie und Dipterologie 5: 33-64, 177-200.

MaA, T. 1949: A synopsis of Asiatic Siricoidea with notes on certain exotic and fossil forms (Hymenoptera Symphyta). - Musée Heude, Notes d'Entomologie Chinoise 13: 11-189.

Mecke, R.; Barboxa, M. S. \& Engels, W. 2001: A new Brasilian sawfly, Derecyrta araucariae spec. nov. (Hymenoptera: Xiphydriidae), associated with Araucaria angustifolia (Bert.) O. Kuntze. - Journal of the Kansas Entomological Society 73: 177-182.

Mocsáry, A. 1891: Tenthredinidae et Siricidae novae. - Természetrajzi Füzetek 14: 155-159.

Mocsáry, A. 1900: Siricidarum species duae novae - Természetrajzi Füzetek 23: 126-127. 
RieK, E. F. 1955: The Australian Xiphydriidae (Hymenoptera Symphyta). - Australian Journal of Zoology 3: $281-285$.

Rohwer, S. A. 1921: Notes on sawflies, with descriptions of new genera and species. - Proceedings of the United States National Museum 59: 83-109.

Ross, H. H. 1937: A generic classification of the Nearctic sawflies (Hymenoptera, Symphyta). - Illinois Biological Monographs 15: 1-173.

SAINI, M.S. \& SingH, D. 1987: A new genus and a new species of Xiphydriidae (Insecta, Hymenoptera, Symphyta) from India. - Zoologica Scripta 16: 355-356.

Sмith, D. R. 1976: The xiphydriid woodwasps of North America (Hymenoptera: Xiphydriidae). Transactions of the American Entomological Society 102: 101-131.

Sмiтh, D. R. 1978: Suborder Symphyta (Xyelidae, Pararchexyelidae, Parapamphiliidae, Xyelydidae, Karatavitidae, Gigasiricidae, Sepulcidae, Pseudosiricidae, Anaxeylidae, Siricidae, Xiphydriidae, Paroryssidae, Xyelotomidae, Blasticotomidae, Pergidae). - In: van der Vecht, J. \& Shenefelt, R. D. (eds.): Hymenopterorum Catalogus, Pars 14. - Dr. W. Junk B. V., Publishers, The Hague, The Netherlands. vi + 193 pp.

Sмiтh, D. R. 1988: A synopsis of the sawflies (Hymenoptera: Symphyta) of America south of the United States: Introduction, Xyelidae, Pamphiliidae, Cimbicidae, Diprionidae, Xiphydriidae, Siricidae, Orussidae, Cephidae. - Systematic Entomology 13: 205-261.

Sмith, D. R. 1995a: A new species of Xiphydriidae (Hymenoptera) from Chile. - Revista Chileana de Entomologia 22: 21-24.

Smith, D. R. 1995b: Rediscovery of Corynophilus pumilus (KLUG), and a new genus and two new species of Symphyta from South America (Hymenoptera, Pergidae \& Xiphydriidae). - Revista Brasileira Entomologia 39: 161-169.

Sмiтh, D. R. 2004: A new species of Derecyrta Sмiтн (Hymenoptera: Xiphydriidae) from Colombia and Ecuador. - Proceedings of the Entomological Society of Washington 106: 675-678.

SMith, F. 1859: Catalogue of hymenopterous insects collected by Mr. A. R. WALLACE at the islands of Aru and Key. - Journal of Proceedings of the Linnean Society of London, Zoology 3: 132-178.

Smith, F. 1861: Catalogue of hymenopterous insects collected by Mr. A. R. Wallace on the islands of Bachian, Kaissa, Amboyna, Gilolo, and at Dory in New Guinea - Journal of Proceedings of the Linnean Society of London, Zoology 5: 93-143.

TAEger, A. \& Blank, S. M. 2006: ECatSym - Electronic World Catalog of Symphyta (Insecta, Hymenoptera). - Version 2.0 (August 11, 2006). ECatSym Online Service, Müncheberg, http://www.zalf.de/home_zalf/ institute/dei/php_e/ecatsym/ecatsym/php.

Taeger, A.; Blank, S. M. \& Liston, A. D. 2006: European sawflies (Hymenoptera: Symphyta) - a species checklist for the countries, pp. 399-504. - In: Blank, S. M.; Schmidt, S. \& Taeger, A. (eds.): Recent Sawfly Research: Synthesis and Prospects. - Goecke \& Evers, Keltern. 702 pp. + 16 pls.

Valentine, E. W. 1970: A list of the phytophagous Hymenoptera in New Zealand. - New Zealand Entomologist 4: 52-62.

Vilhelmsen, L. \& Sмith, D. R. 2002: Revision of the 'ophrynopine' genera Argentophrynopus gen. n., Guiglia Benson, Kulcania Benson, Ophrella Middlekauff, Ophrynon Middlekauff, Ophrynopus Konow, and Stirocorsia Konow (Hymenoptera: Orussidae). - Insect Systematics and Evolution 33: $387-420$.

WeI, M. 2002: Hymenoptera: Xiphydriidae, pp. 856-859. - In: Huang, F. (ed.): Forest Insects of Hainan.National Natural Science Foundation of China.

WeI, M. \& XIAO, W. 1999: Three new genera and species of Xiphydriidae from south slope of Mt. Funin (Hymenoptera: Siricomorpha), pp. 147-148. - In: Shen, X. \& Pei, H. (eds.): Insects of the mountains Funiu and Dabie regions. - The Fauna and Taxonomy of Insects in Hunan. Vol. 4. - China Agricultural Science and Technology Press: 415 pp. 
Westwood, J. O. 1874: Thesaurus Entomologicus Oxoniensis; or, illustrations of new, rare, and interesting insects, for the most part contained in the collections presented to the University of Oxford by the Rev. F. W. Hope, M.A., D.C.L., F.R.S. \&c, with forty plates from drawings by the author. - Oxford: 205 pp. +40 plates.

Zirngiebl, L. 1939: Veränderungen am Flügelgeäder von Xiphydria prolongata Geoff. - Abhandlungen Herausgegeben von Naturwissenschaftlichen Verein zu Bremen 31: 106-108.

\section{Index}

Valid names are in roman, synonyms in italics, pages bold = description, underlined = image

Alloxiphia Wei, 2002

18,21

Apoxiphia Maa, 1949

21

araucariae Mecke, 2001, Derecyrta

16,64

australiensis Riek, 1955, Austrocyrta

... 17

Austrocyrta Riek, 1955

20,22

banahao Smith, Obesaxiphyda

$15,16,50,51, \underline{88}$

betulae (Enslin, 1911), Konowia

19

blanki Smith, Calexiphyda

$15,32,33,34, \underline{76}$

borneensis (Rohwer, 1921), Obesaxiphyda

caledonica Smith, Calexiphyda

$15,16,50,51,52,53, \underline{89}$

Calexiphyda Smith 36

camelus (Linnaeus, 1758), Xiphydria

$19,20,23,24,32,33,34,36$

Carinoxiphia Wei, 1999

.... 18

Cingalixiphia Maa, 1949

18,21

crocea Smith, Calexiphyda

$15,16,20,21,37$

cyanea (Mocsáry, 1891), Hyperxiphia

$15,32,35,77$

darlingi Smith, Indoxiphia

$16,55,56, \underline{90}$

Derecyrta F. Smith, 1860

$15,39,78$

Dryxiphia Maa, 1949

$18,19,21$

erythropus (Cameron, 1903), Lataxiphyda

Euxiphydria Semenov 1935

$15,16,59,60,61,62, \underline{93}$
$\ldots \ldots \ldots \ldots \ldots \ldots \ldots \ldots .18,21$
$16,54,55,50,49, \underline{79}$
$15,57,63, \underline{91}$

falcata Smith, Indoxiphia

$15,16,59,60,61,62, \underline{93}$
$\ldots \ldots \ldots \ldots \ldots \ldots \ldots \ldots \ldots .18,18,21$
$16,54,55,56,57,63, \underline{91}$

fijiensis Smith, Indoxiphia

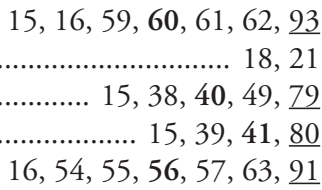

flavicornis (Rohwer, 1921), Hyperxiphia

$15,16,59,60,61,62, \underline{93}$
$\ldots \ldots \ldots \ldots \ldots \ldots \ldots \ldots .18,21$
$16,54,55,50,49, \underline{79}$
$15,57,63, \underline{91}$

formosana (Enslin, 1911), Hyperxiphia

Genaxiphia Maa, 1949

$15,16,54$

Gryponeura Benson, 1954

18,21

heritierae (Rohwer, 1921), Obesaxiphyda

19,21

Heteroxiphia Saini and Singh, 1987

Hyperxiphia Maa, 1949

$15,16,50,51,52,53$
$\ldots \ldots \ldots \ldots \ldots \ldots \ldots . .18,21$

Indoxiphia Maa, 1949

$15,16,18,19,21,23,54,56,57,61,63$

kiunga Smith, Lissoxiphyda

Konowia Brauns, 1884

$15,25,26,31, \underline{68}$

laeviceps (F. Smith, 1861), Indoxiphia

21,64

Lataxiphyda Smith

$15,38,42,43,44, \underline{81}$

Lissoxiphyda Smith

$15,16,18,19,20,22,23,50,58,62$

lucida Smith, Lissoxiphyda

$15,16,18,19,20,22,23,24,26,27,32,33$

maai Smith, Indoxiphia

$15,25,26,27,28,29, \underline{69}$

megapolitana (Brauns, 1884), Konowia

$15,39,44,45,50, \underline{82}$ 
Megaxiphia Wei, 1999

18,21

melanopus Cameron, 1903, Xiphydria $60,61, \underline{93}$

Moaxiphia Maa, 1949 $17,18,20,22,23,24,32$

morobe Smith, Lissoxiphyda $15,25,27,29,70$

Nasoxiphia Maa, 1949 …............. 18, 21

novacaledonica (Jennings and Austin, 2007), Calexiphyda Obesaxiphyda Smith Palpixiphia Maa, 1949 $15,16,17,36,64$
$19,20,22,23,50$

papuaensis Smith, Indoxiphia paraerythropus Smith, Lataxiphyda

Paraxiphia Maa, 1949

Platyxiphydria Takeuchi, 1938

prolongata (Geoffroy, 1785), Xiphydria .

Pseudoxiphydria Enslin, 1911 pyrura (Rohwer, 1921), Lataxiphyda quadricincta (Benson, 1935), Indoxiphia Rhysacephala Benson, 1954 rufipes (F. Smith, 1859), Lissoxiphyda schiffi Smith, Indoxiphia shinoharai Smith, Lissoxiphyda

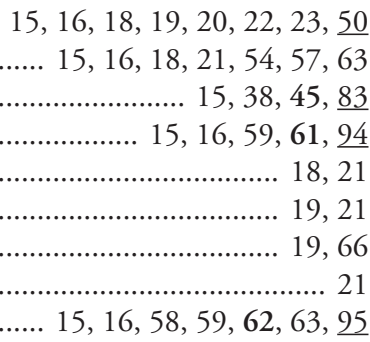

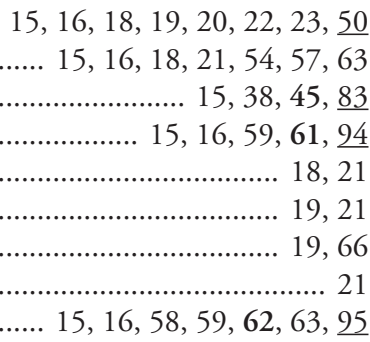
simbai Smith, Lissoxiphyda striatifrons Cameron, 1905, Xiphydria

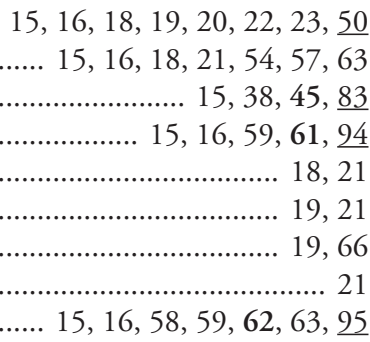
sulawesi Smith, Hyperxiphia sumatra Smith, Indoxiphia

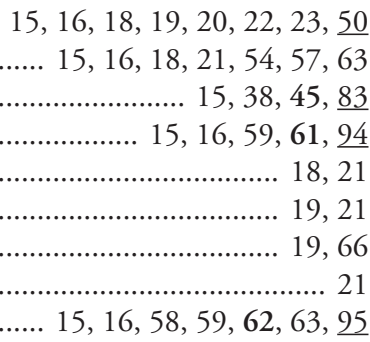
testacea (Mocsáry, 1900), Indoxiphia tripotini Smith, Lissoxiphyda Trixiphidia Wei, 1999

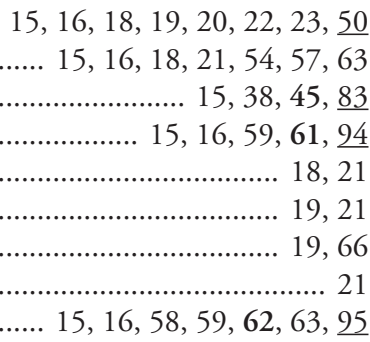

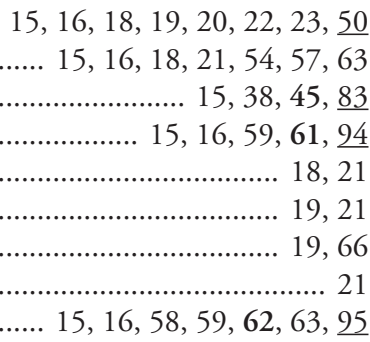
ungulivaria Maa, 1949, Hyperxiphia

Xiphidiaphora Benson, 1954

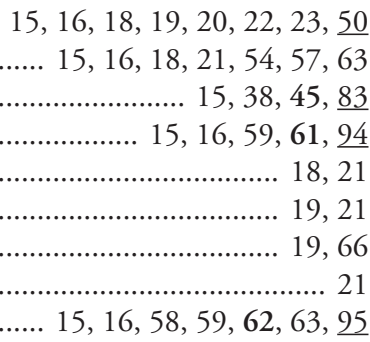

Xiphydria Latreille, 1803

Xiphydriola Semenov, 1921

Yangixiphia Wei, 2002 $15,21,37,39,46, \underline{84}$ $17,18,19,20,22,23,24,32$ $15,24,25,27,28,29,30, \underline{71}$ $15,16,39,47, \underline{85}$ $15,25,29, \underline{72}$ $15,25,26,30,31,73$ $15,16,55,57,22$ $15,16,37,38,39,48,49, \underline{86}$ $15,16,38,49,50, \underline{87}$ $15,22,24,25,26,29,31, \underline{74}$ 18,21 .. 54 19 $16,18,21$ $19,20,37,46$ 18,21

Author's address:

DAVID R. SMITH

Systematic Entomology Laboratory, PSI

Agricultural Research Service

U.S. Department of Agriculture

clo National Museum of Natural History

Smithsonian Institution

P.O. Box 37012, MRC 168

Washington, D.C. 20013-7012

U.S.A.

e-mail: dave.smith@ars.usda.gov

\section{Subject editor:}

Dr. A. TAEgER 

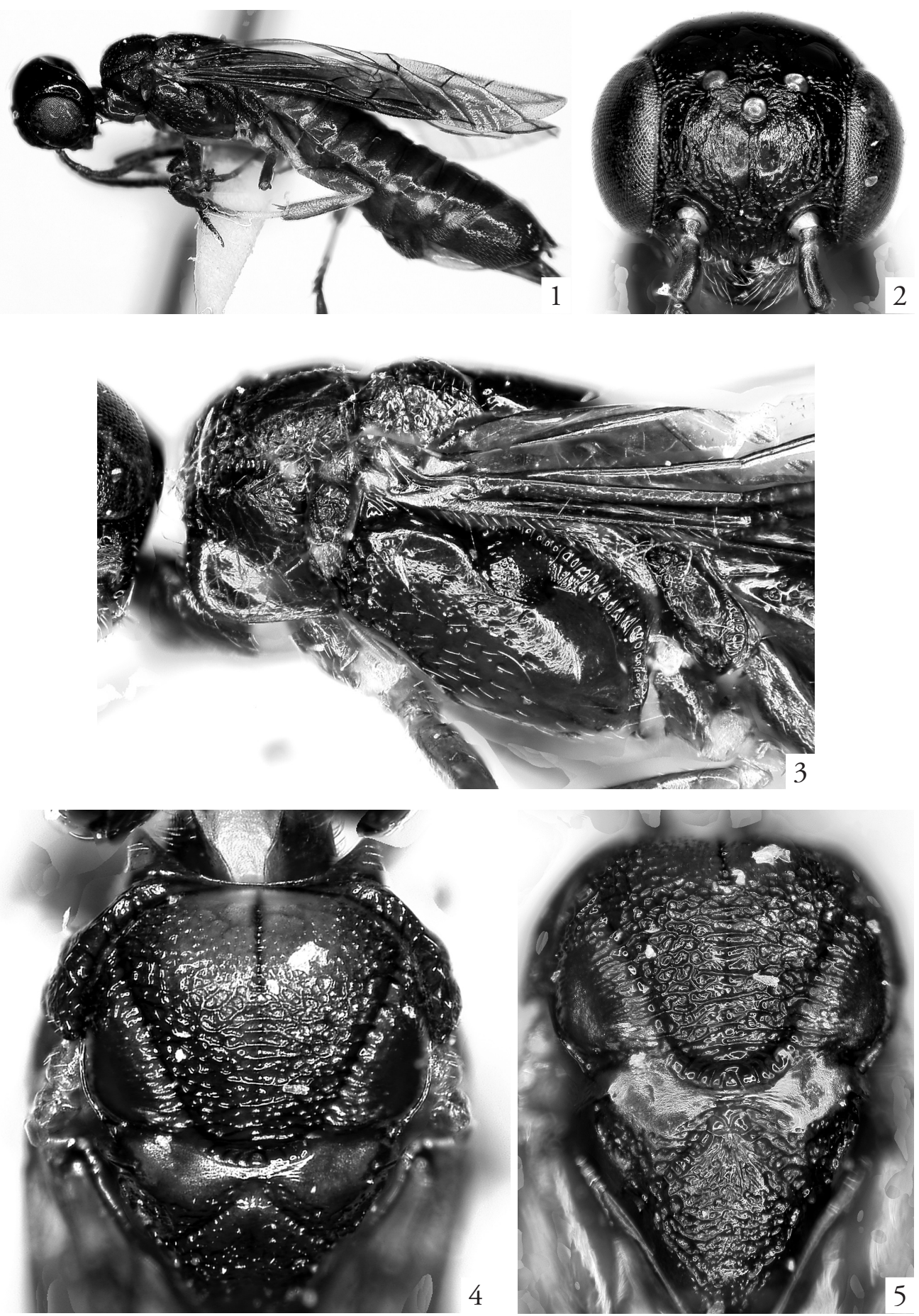

Figs 1-5: Lissoxiphyda kiunga, holotype. 1 Lateral. 2 Head, front. 3 Thorax, lateral. 4 Pronotum and mesoscutum, dorsal. 5 Mesonotum, dorsal. 

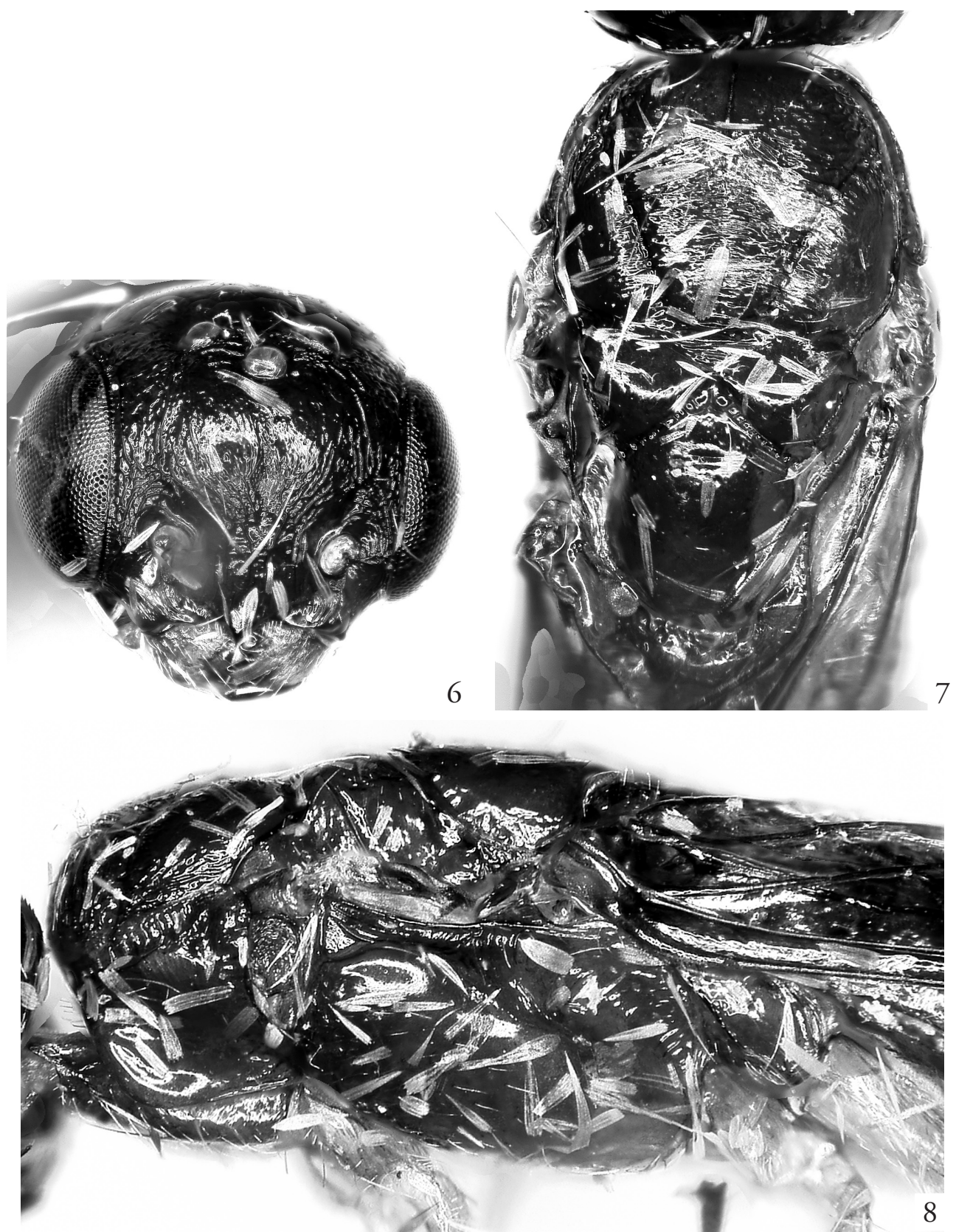

Figs 6-8: Lissoxiphyda lucida, holotype. 6 Head, front. 7 Thorax, dorsal. 8 Thorax, lateral. 

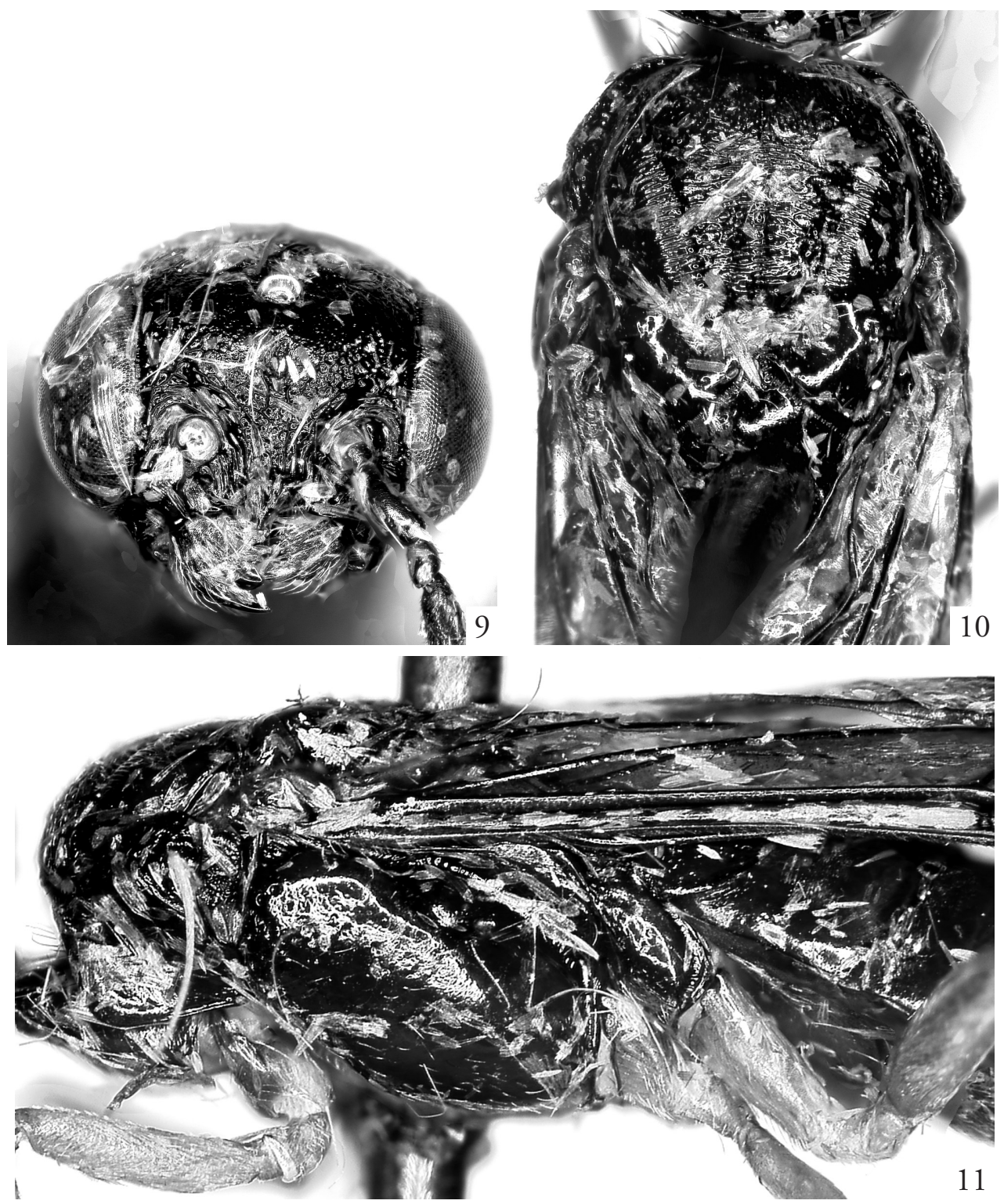

Figs 9-11: Lissoxiphyda morobe, holotype. 9 Head, front. 10 Thorax, dorsal. 11 Thorax, lateral. 

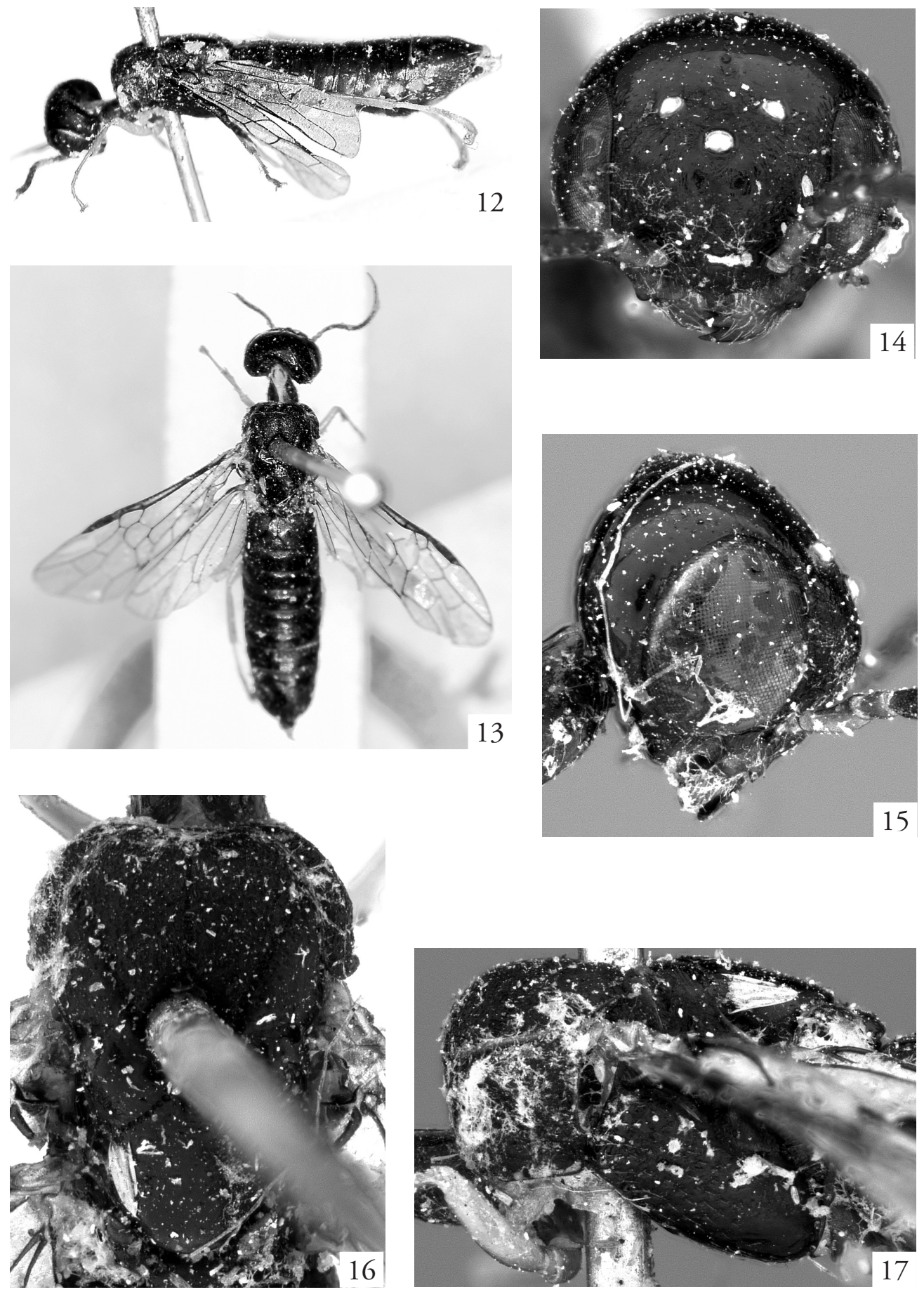

Figs 12-17: Lissoxiphyda rufipes, holotype. 12 Lateral. 13 Dorsal. 14 Head, front. 15 Head, lateral. 16 Thorax, dorsal. 17 Thorax, lateral. 

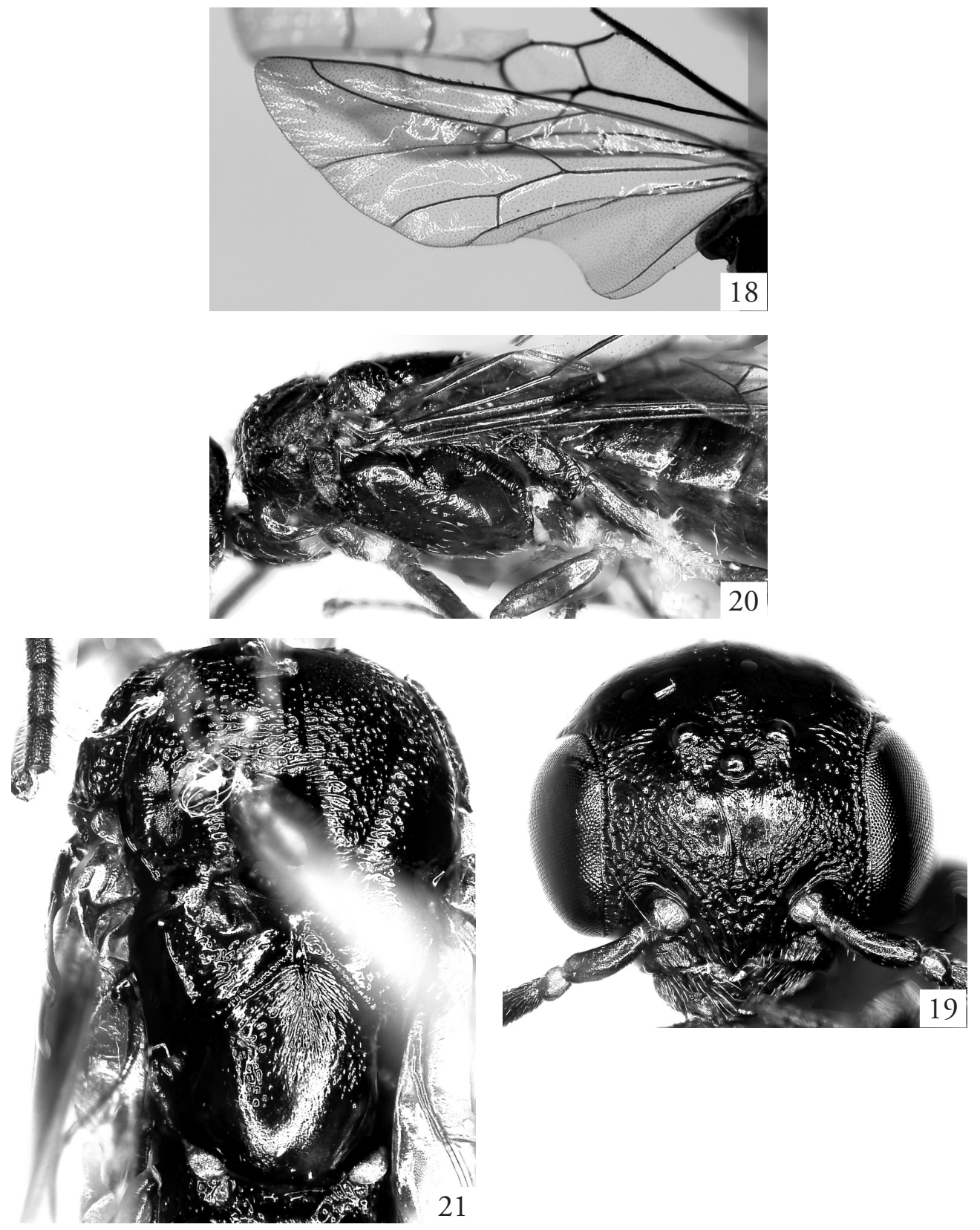

Figs 18-21: Lissoxiphyda shinoharai, holotype. 18 Wings. 19 Head, front. 20 Thorax, lateral. 21 Thorax, dorsal. 

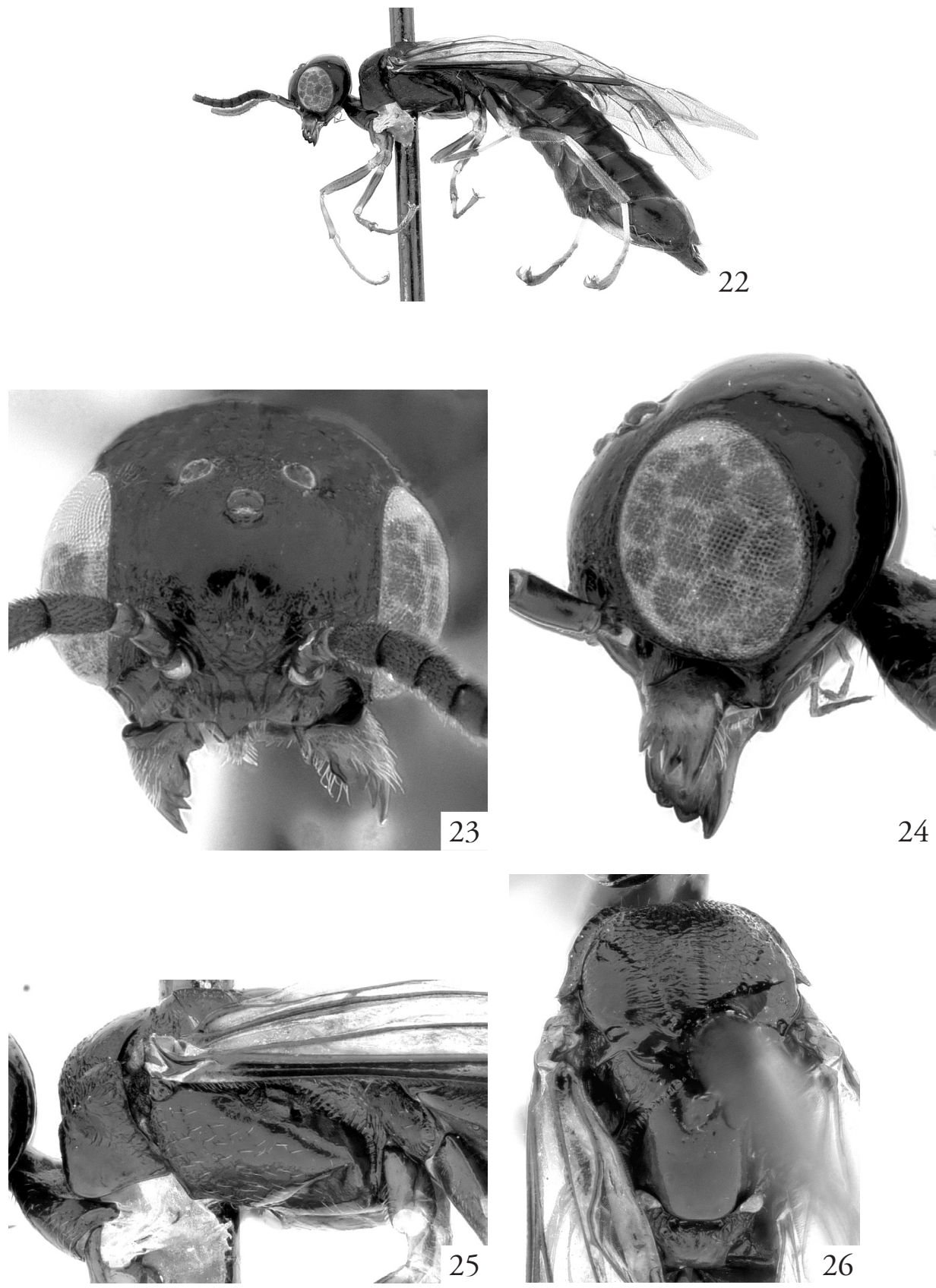

Figs 22-26: Lissoxiphyda simbai, holotype. 22 Lateral. 23 Head, front. 24 Head, lateral. 25 Thorax, lateral. 26 Thorax, dorsal. 

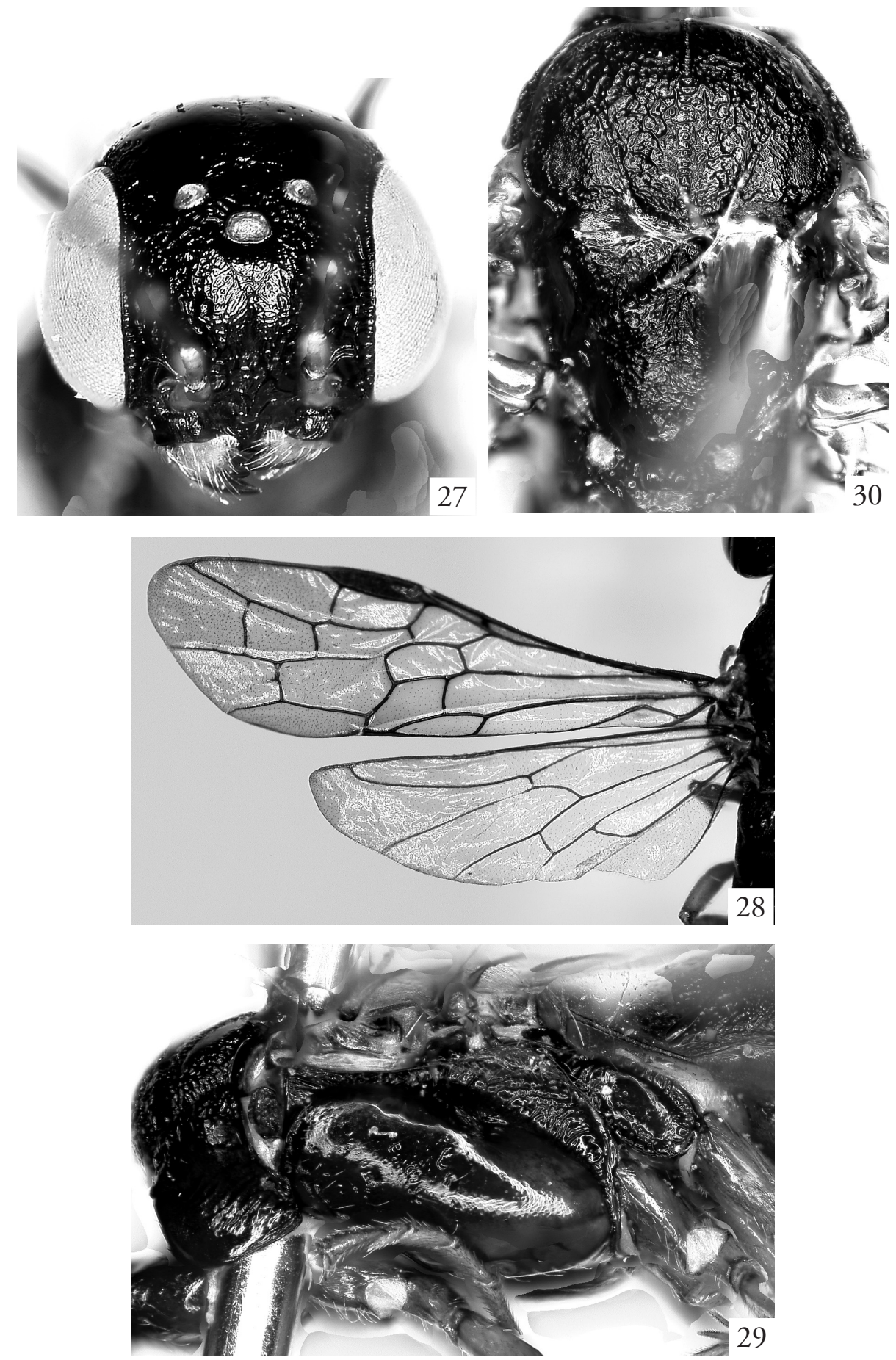

Figs 27-30: Lissoxiphyda tripotini. 27 Head, front. 28 Wings. 29 Thorax, lateral. 30 Thorax, dorsal. 

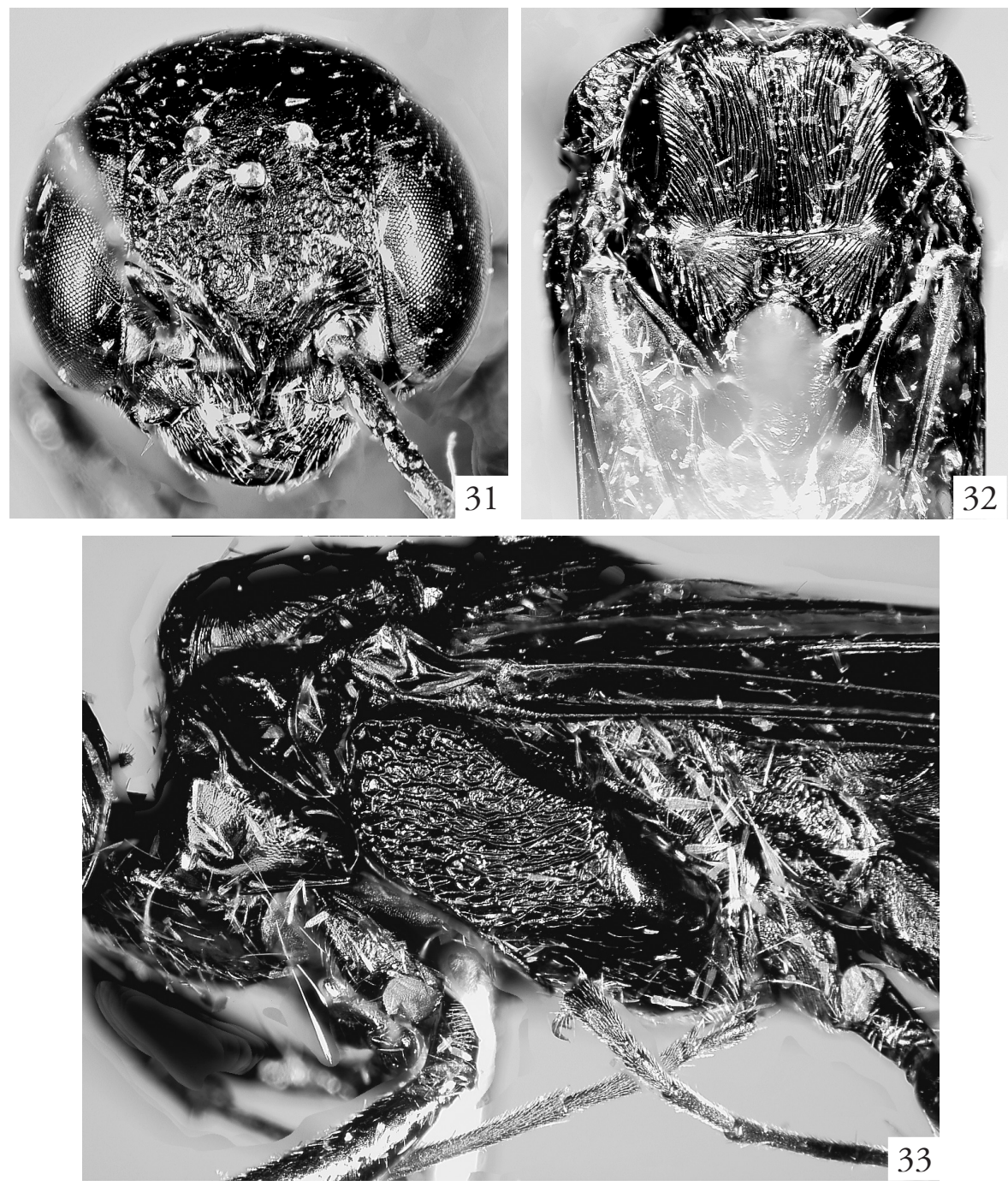

Figs 31-33: Calexiphyda caledonia, holotype. 31 Head, front. 32 Thorax, dorsal. 33 Thorax, lateral. 

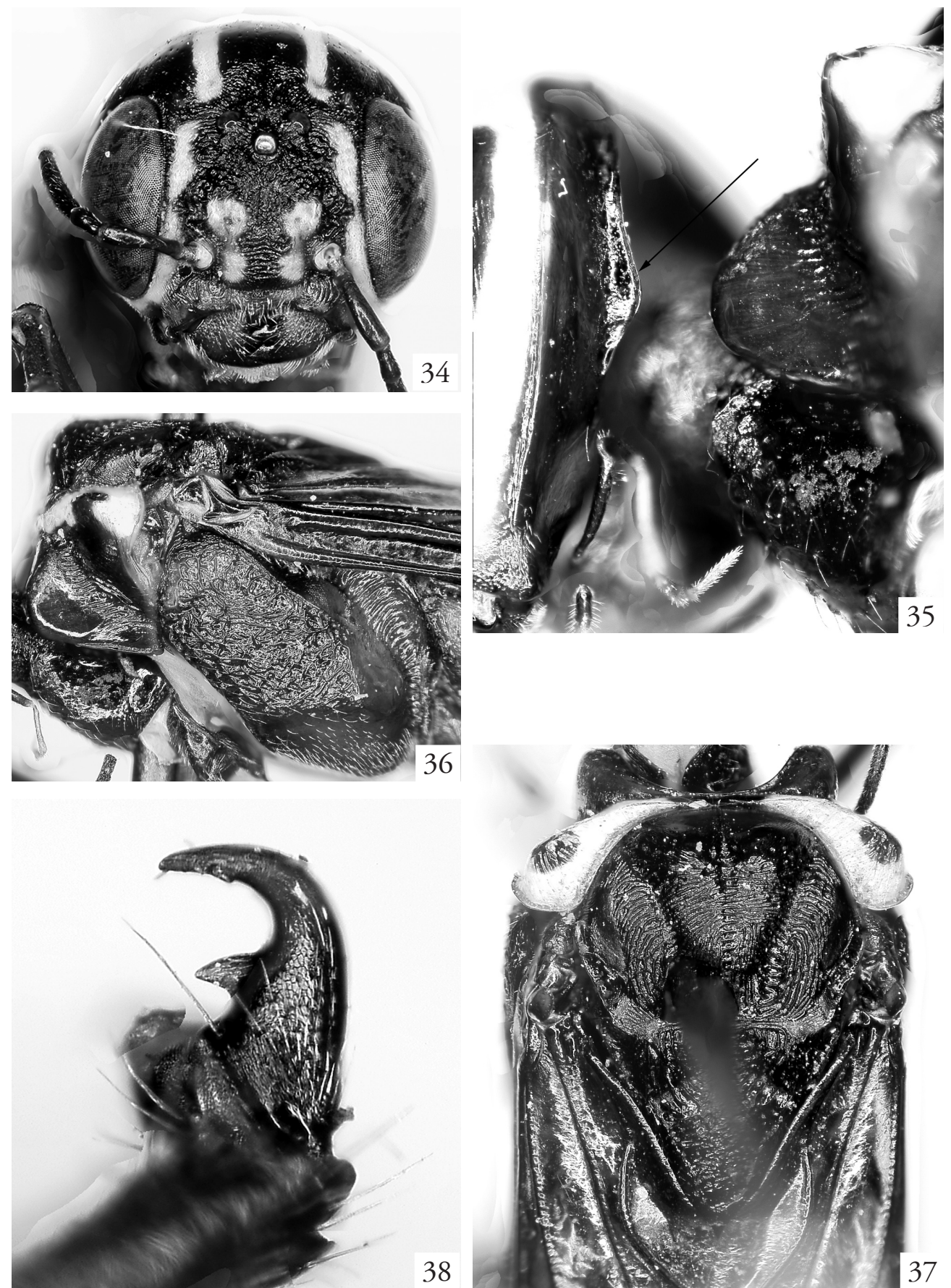

Figs 34-38: Calexiphyda blanki, holotype. 34 Head, front. 35 Head, posterolateral, showing enlarged occipital carina laterally (arrow). 36 Thorax, lateral. 37 Thorax, dorsal. 38 Hind tarsal claw. 

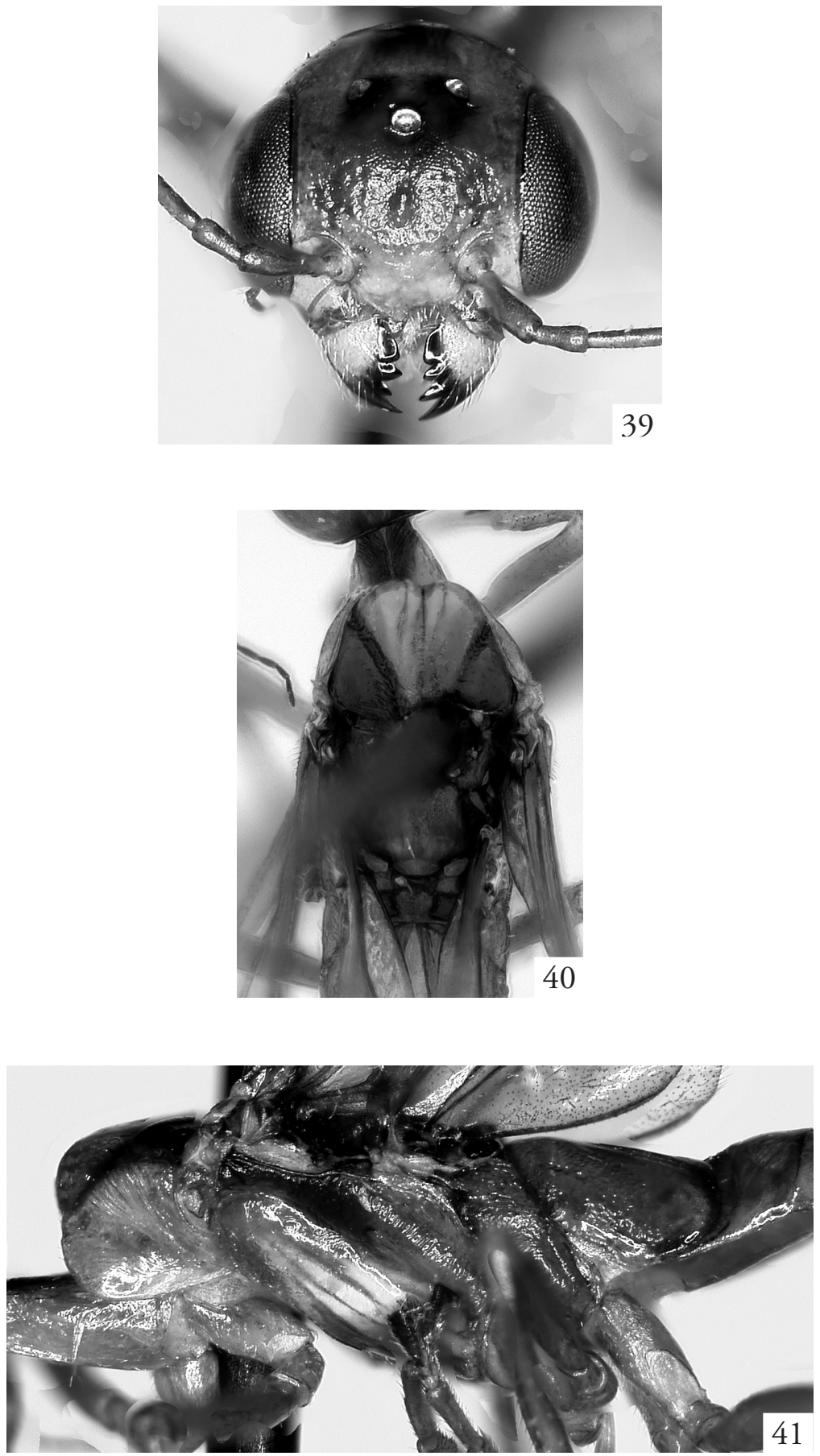

Figs 39-41: Calexiphyda crocea, holotype. 39 Head, front. 40 Thorax, dorsal. 41 Thorax, lateral. 

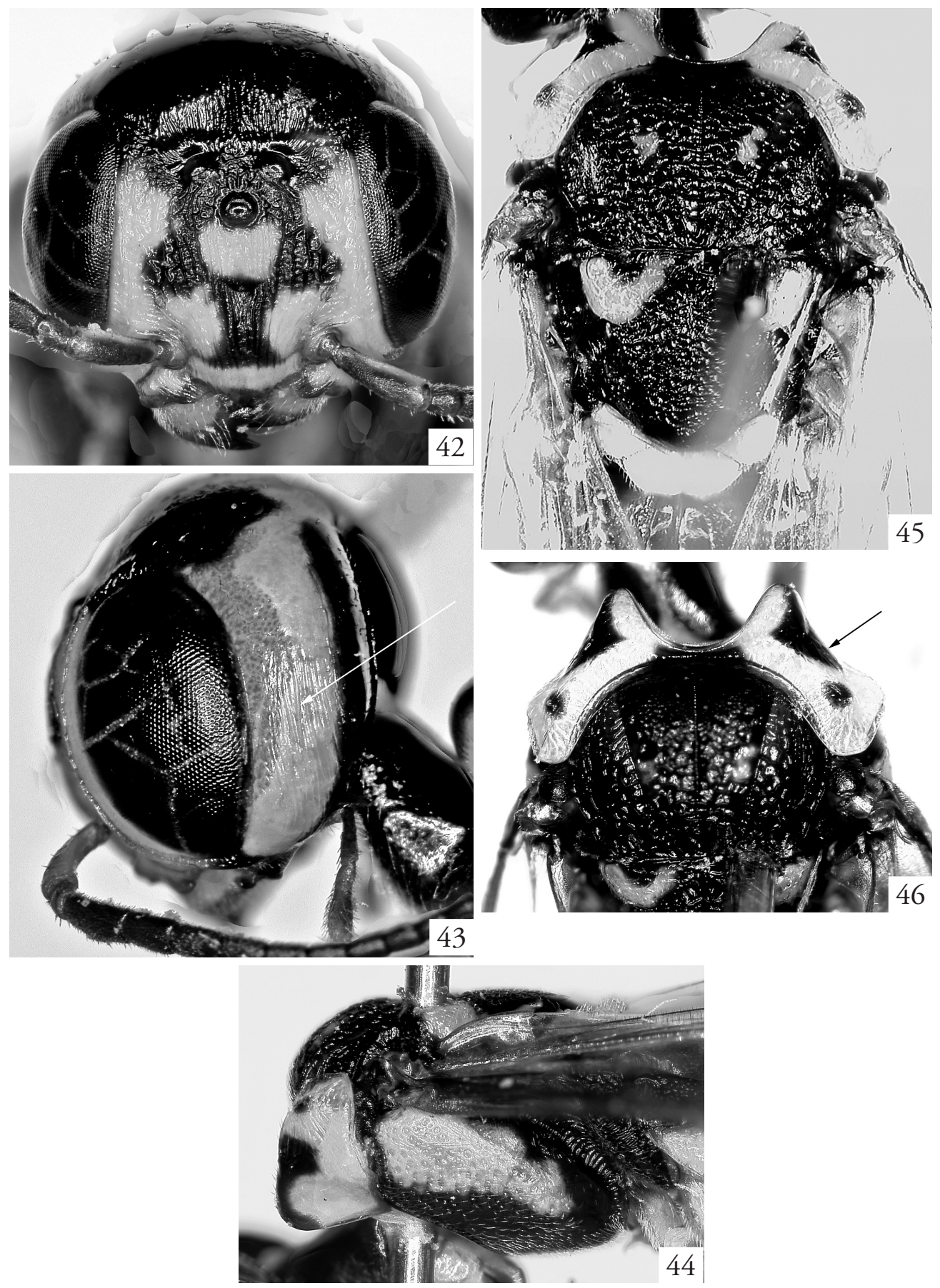

Figs 42-46: Indoxiphia darlingi, holotype. $42 \mathrm{Head}$, front. $43 \mathrm{Head}$, posterolateral, showing carina on gena. 44 Thorax, lateral. 45 Thorax, dorsal. 46 Thorax, dorsal, angled anteriorly to show pronotal collar. 

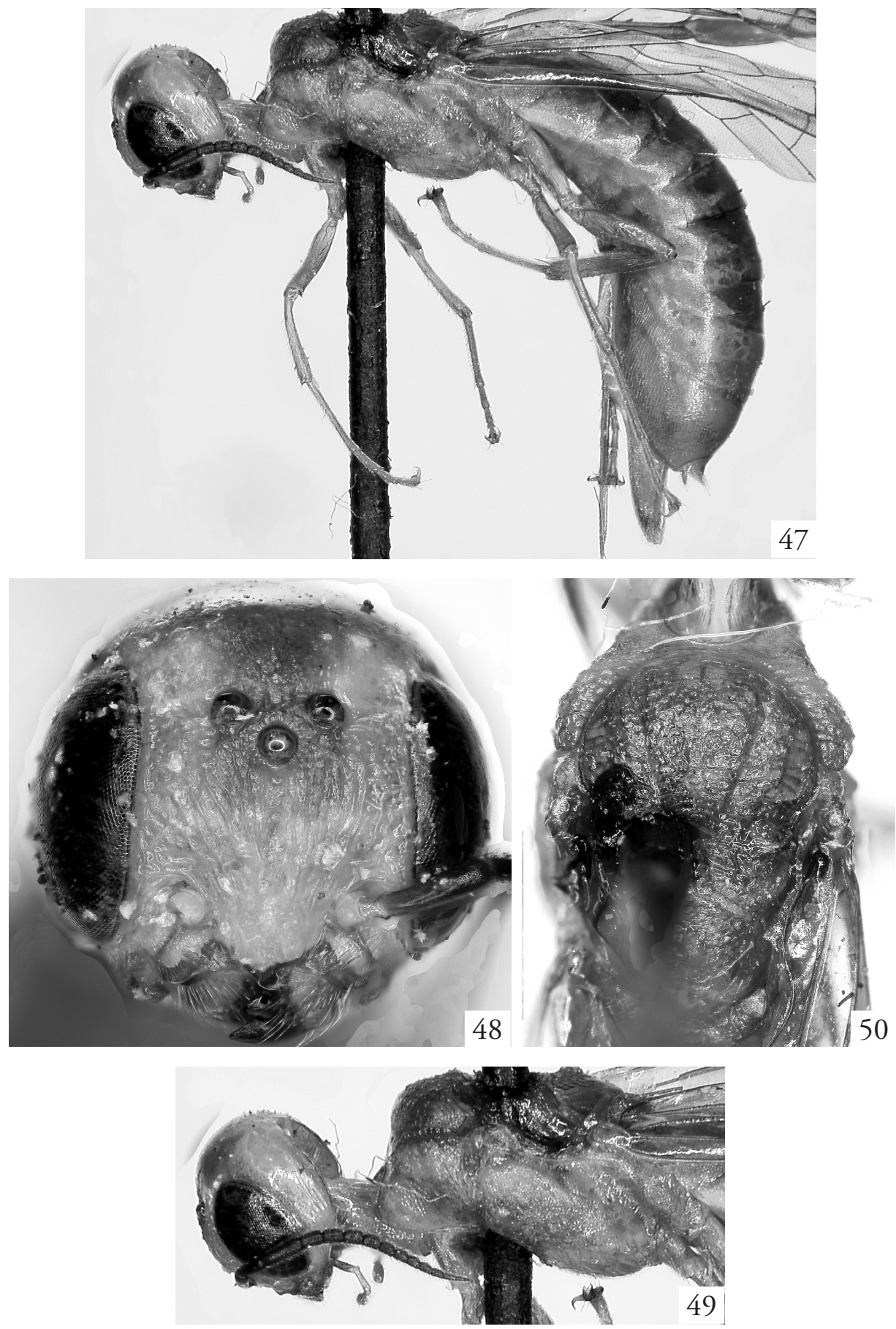

Figs 47-50: Indoxiphia falcata, holotype. 47 Lateral. $48 \mathrm{Head}$, front. $49 \mathrm{Head}$ and thorax, lateral. 50 Thorax, dorsal. 

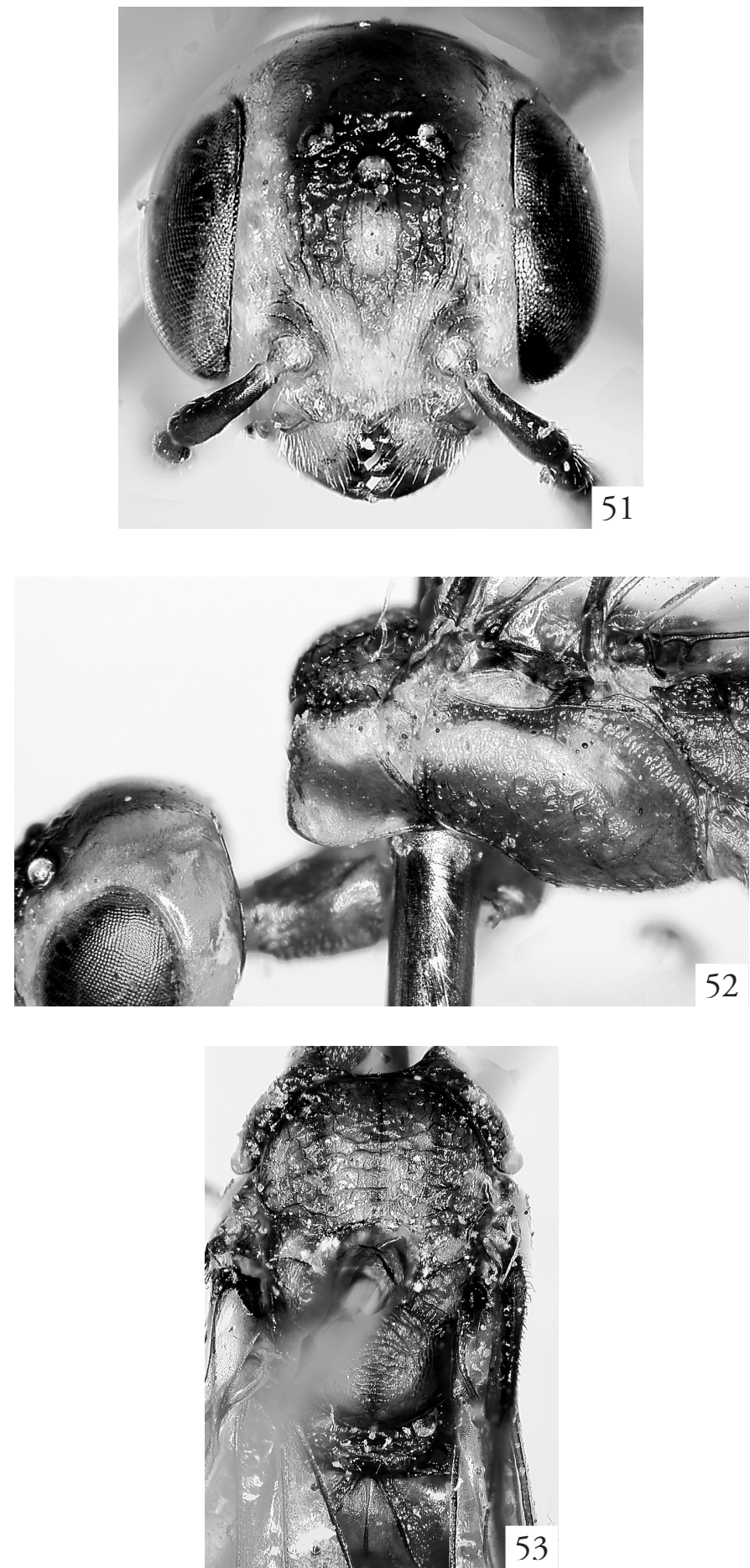

Figs 51-53: Indoxiphia fijiensis, holotype. $51 \mathrm{Head}$, front. $52 \mathrm{Head}$ and thorax, lateral. 53 Thorax, dorsal. 

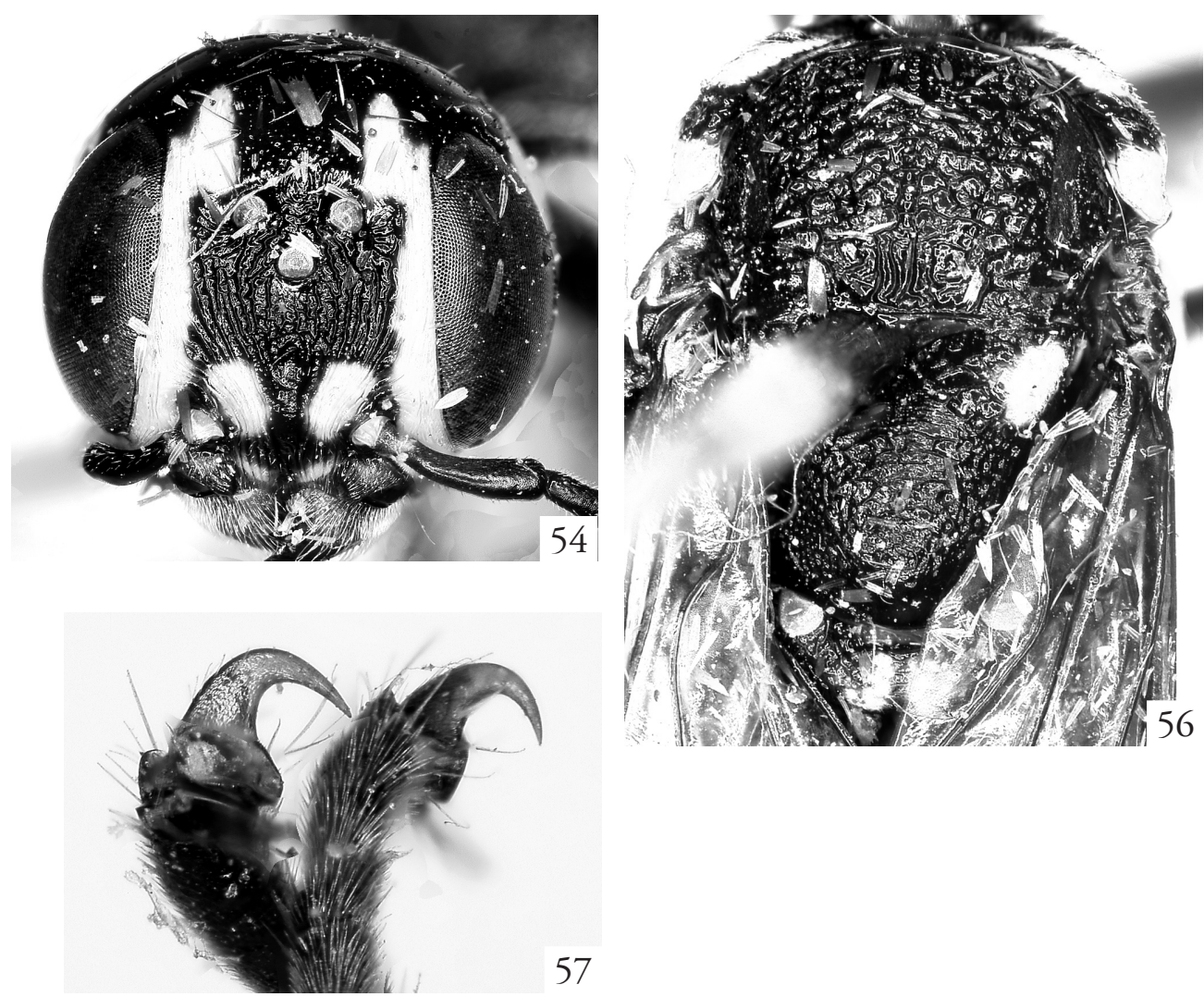

57

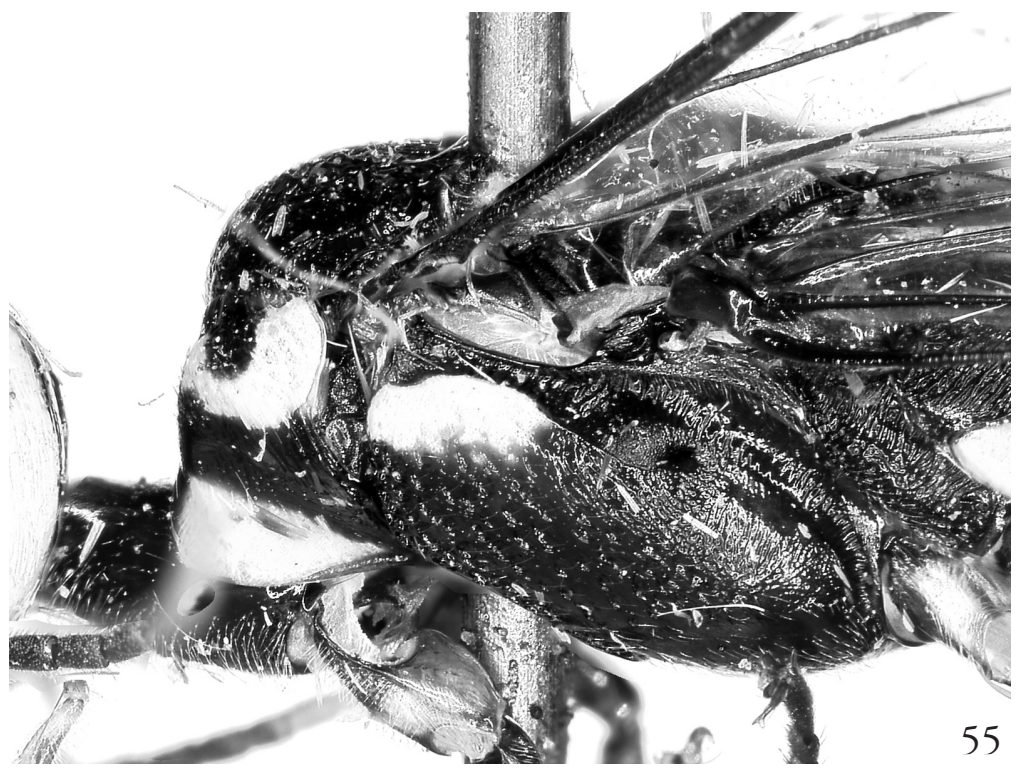

Figs 54-57: Indoxiphia laeviceps, holotype. 54 Head, front. 55 Thorax, lateral. 56 Thorax, dorsal. 57 Hind tarsal claws. 

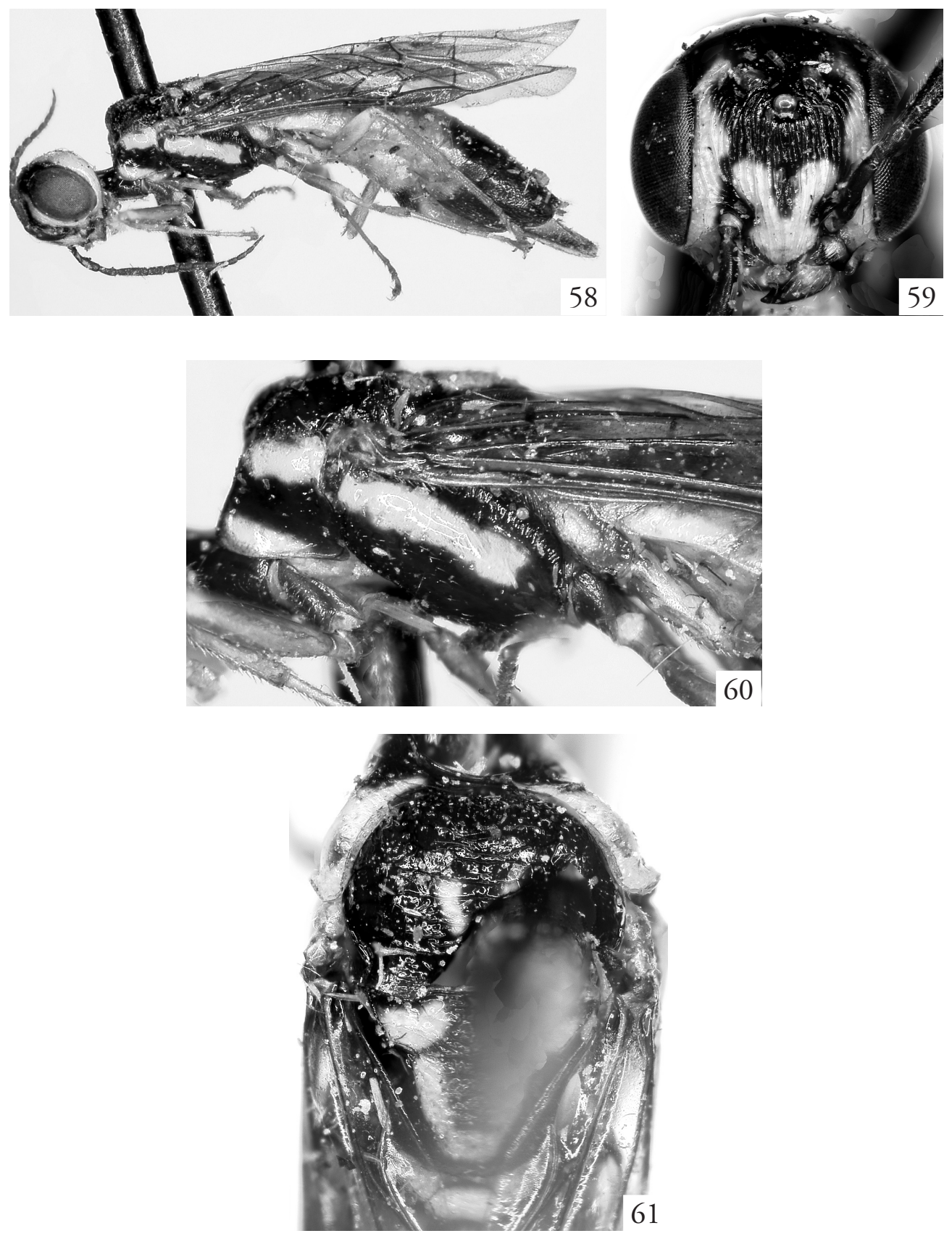

Figs 58-61: Indoxiphia maai, holotype. 58 Lateral. 59 Head, front. 60 Thorax, lateral. 61 Thorax, dorsal. 

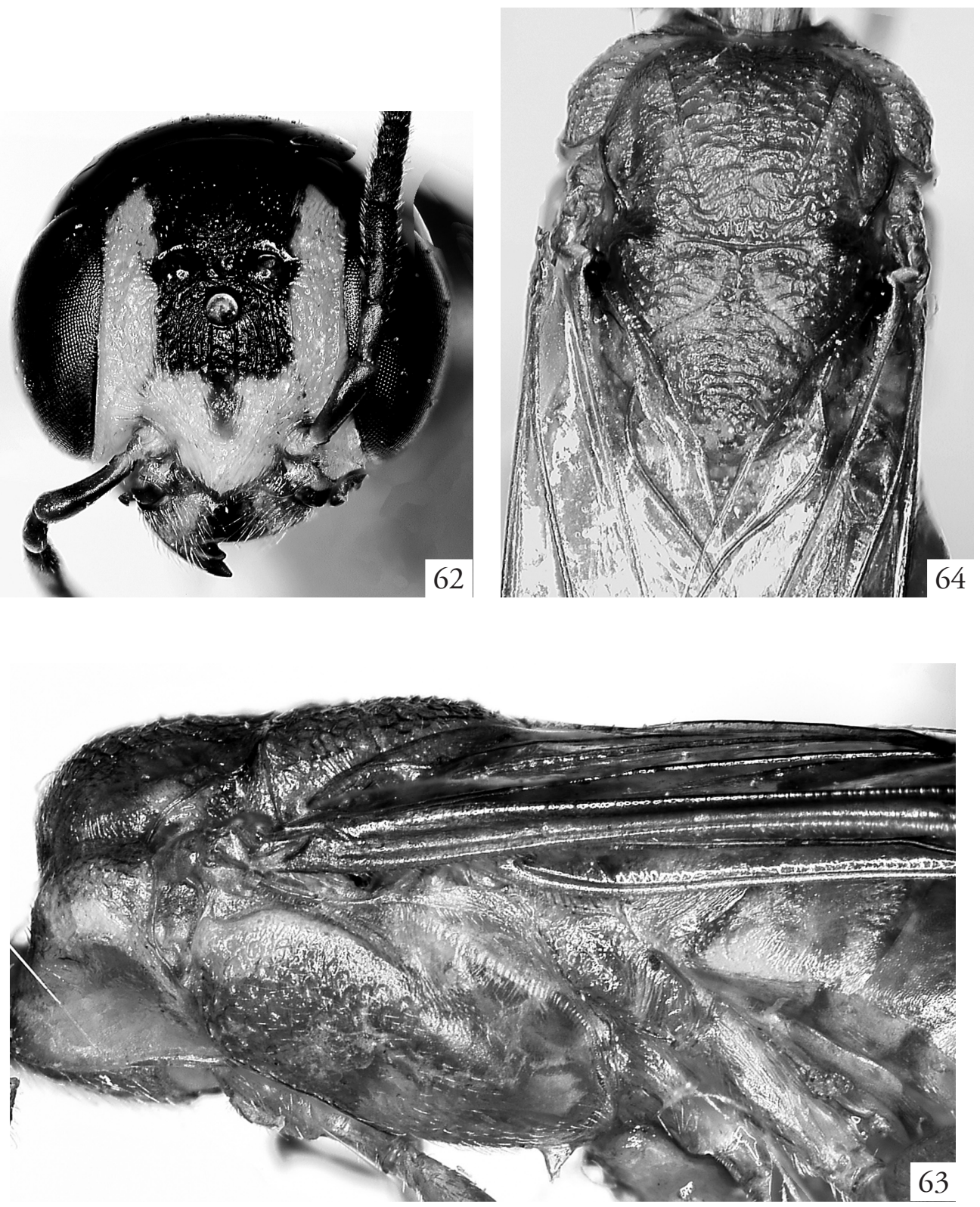

Figs 62-64: Indoxiphia papuaensis, holotype. $62 \mathrm{Head}$, front. 63 Thorax, lateral. 64 Thorax, dorsal. 

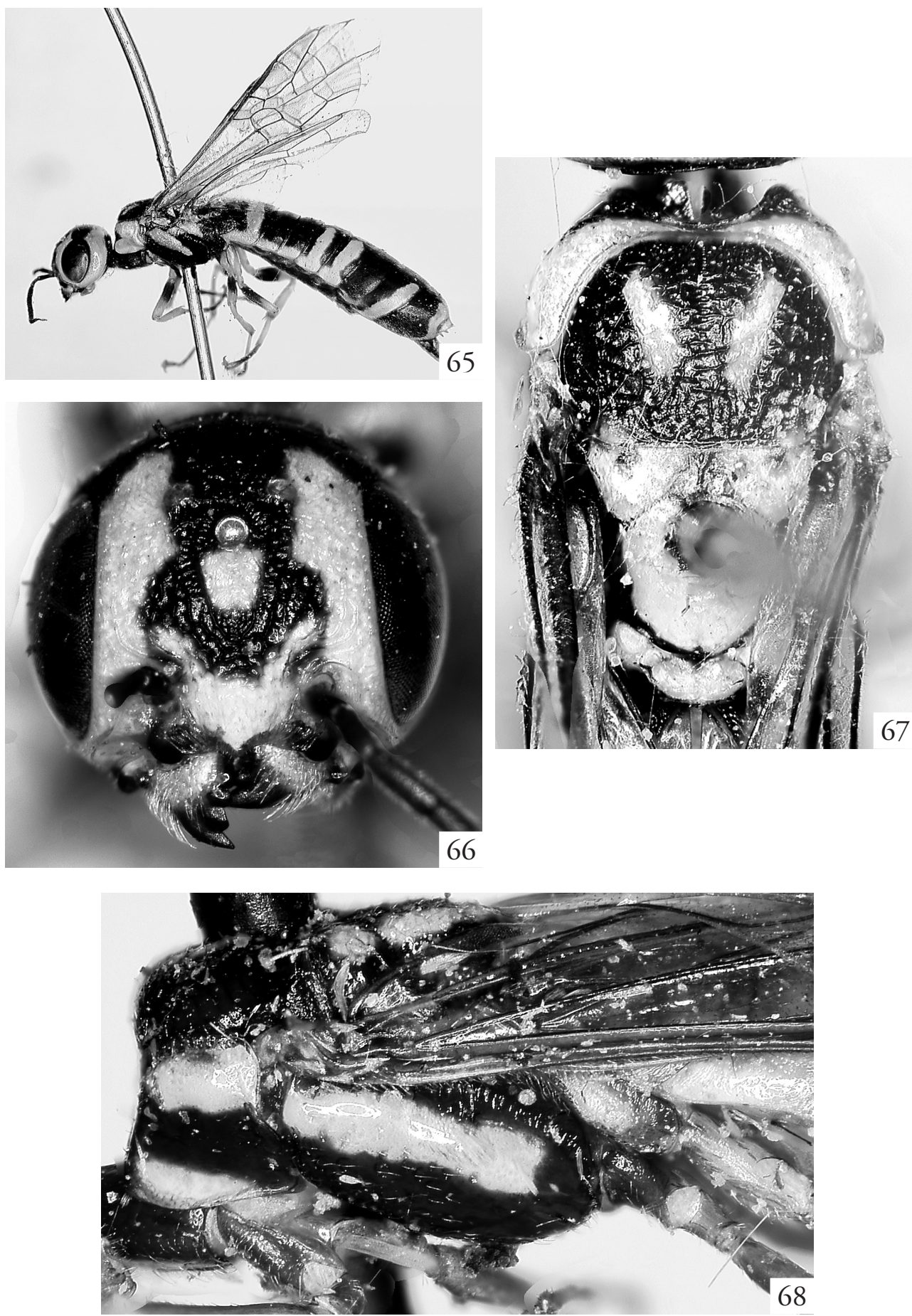

Figs 65-68: Indoxiphia quadricincta, holotype. 65 Lateral. 66 Head, front. 67 Thorax, dorsal. 68 Thorax, lateral. 

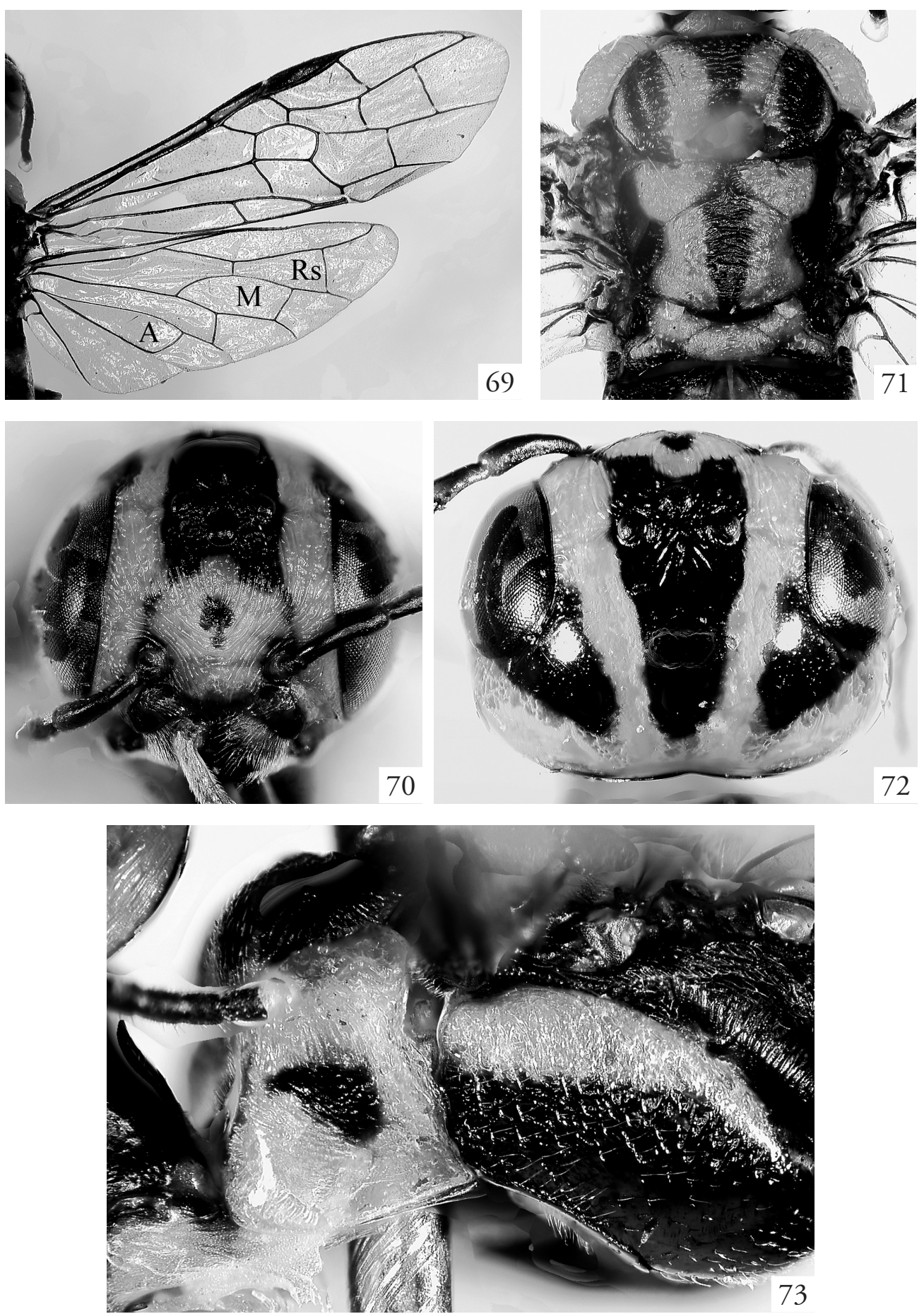

Figs 69-73: Indoxiphia schiffi, holotype. 69 Wings. $70 \mathrm{Head}$, front. 71 Thorax, dorsal. $72 \mathrm{Head}$, dorsal. 73 Thorax, lateral. 

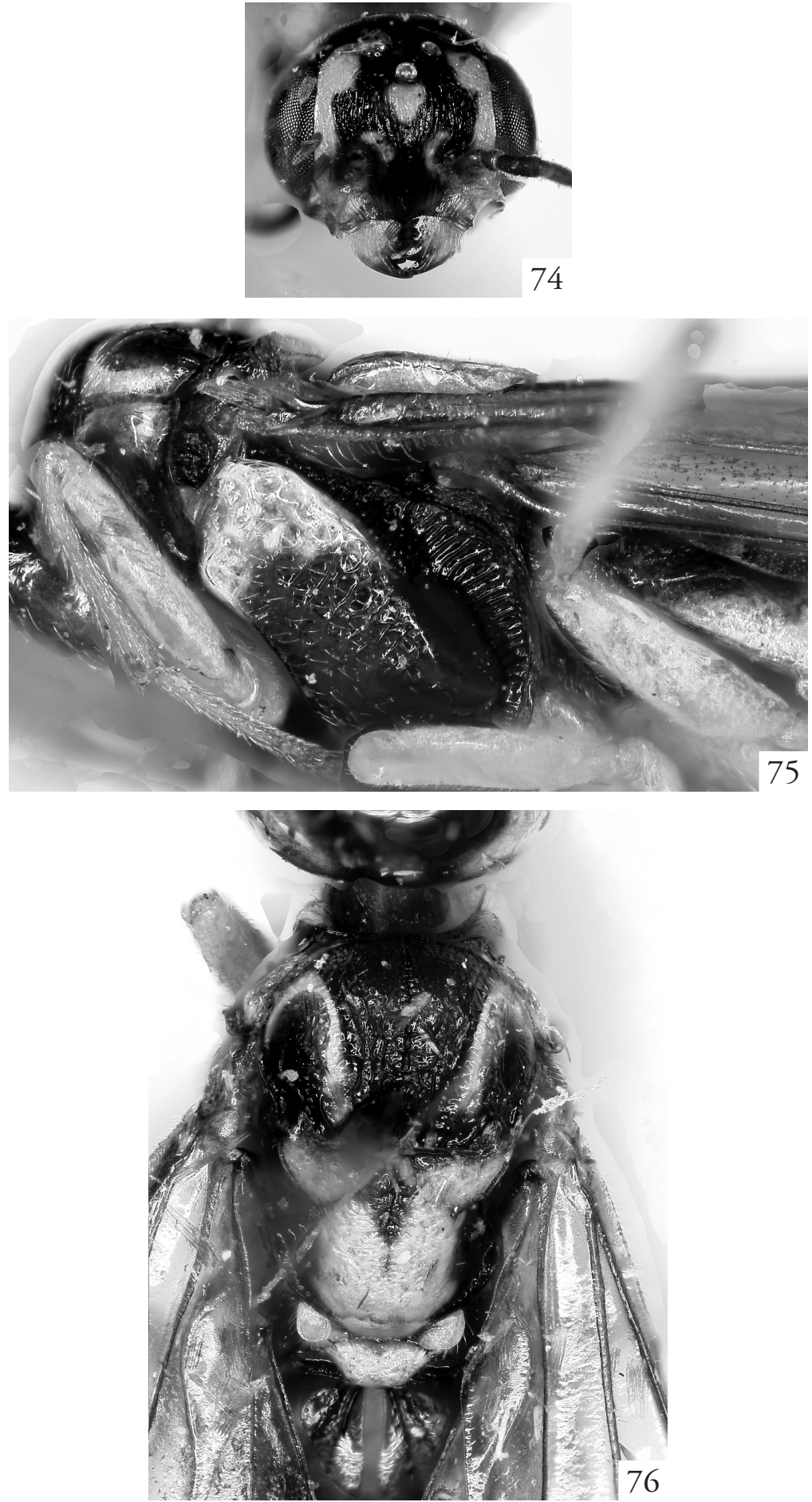

Figs 74-76: Indoxiphia sumatra, holotype. $74 \mathrm{Head}$, front. 75 Thorax, lateral. 76 Thorax, dorsal. 

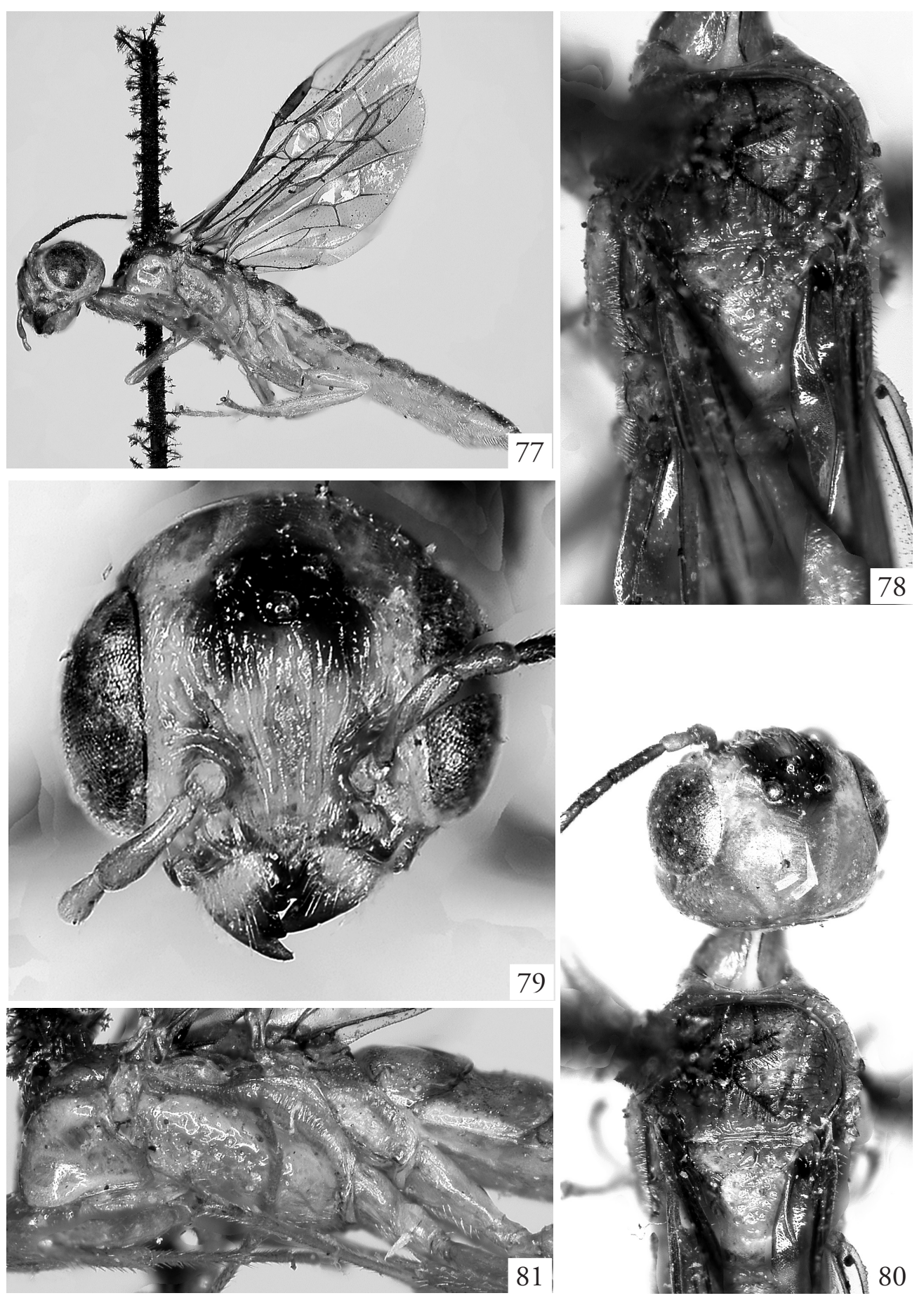

Figs 77-81: Indoxiphia testacea, holotype. 77 Lateral. 78 Thorax, dorsal. 79 Head, front. 80 Head and thorax, dorsal. 81 Thorax, lateral. 

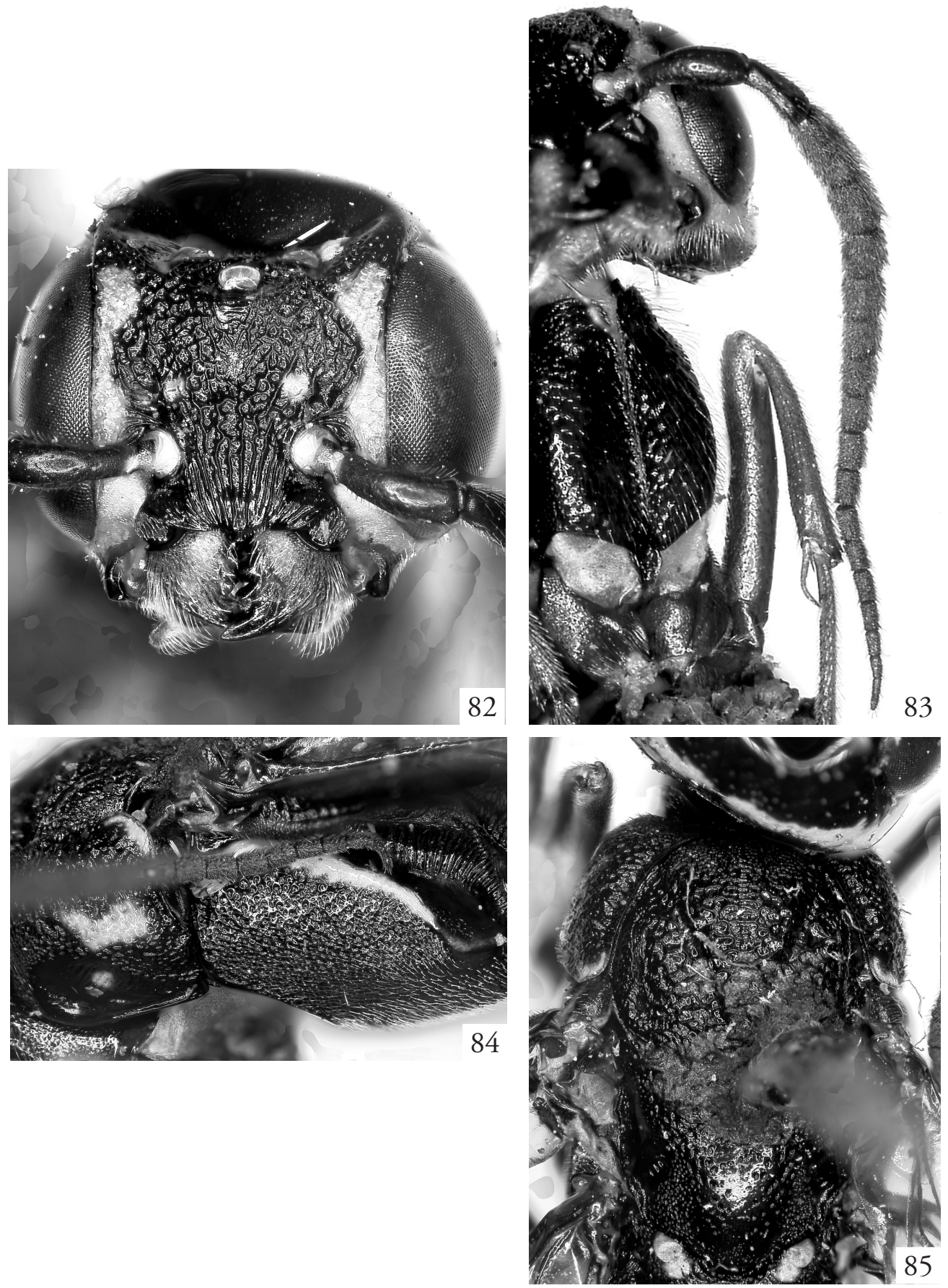

Figs 82-85: Obesaxiphyda banahao, holotype. 82 Head, front. 83 Antenna. 84 Thorax, lateral. 85 Thorax, dorsal. 

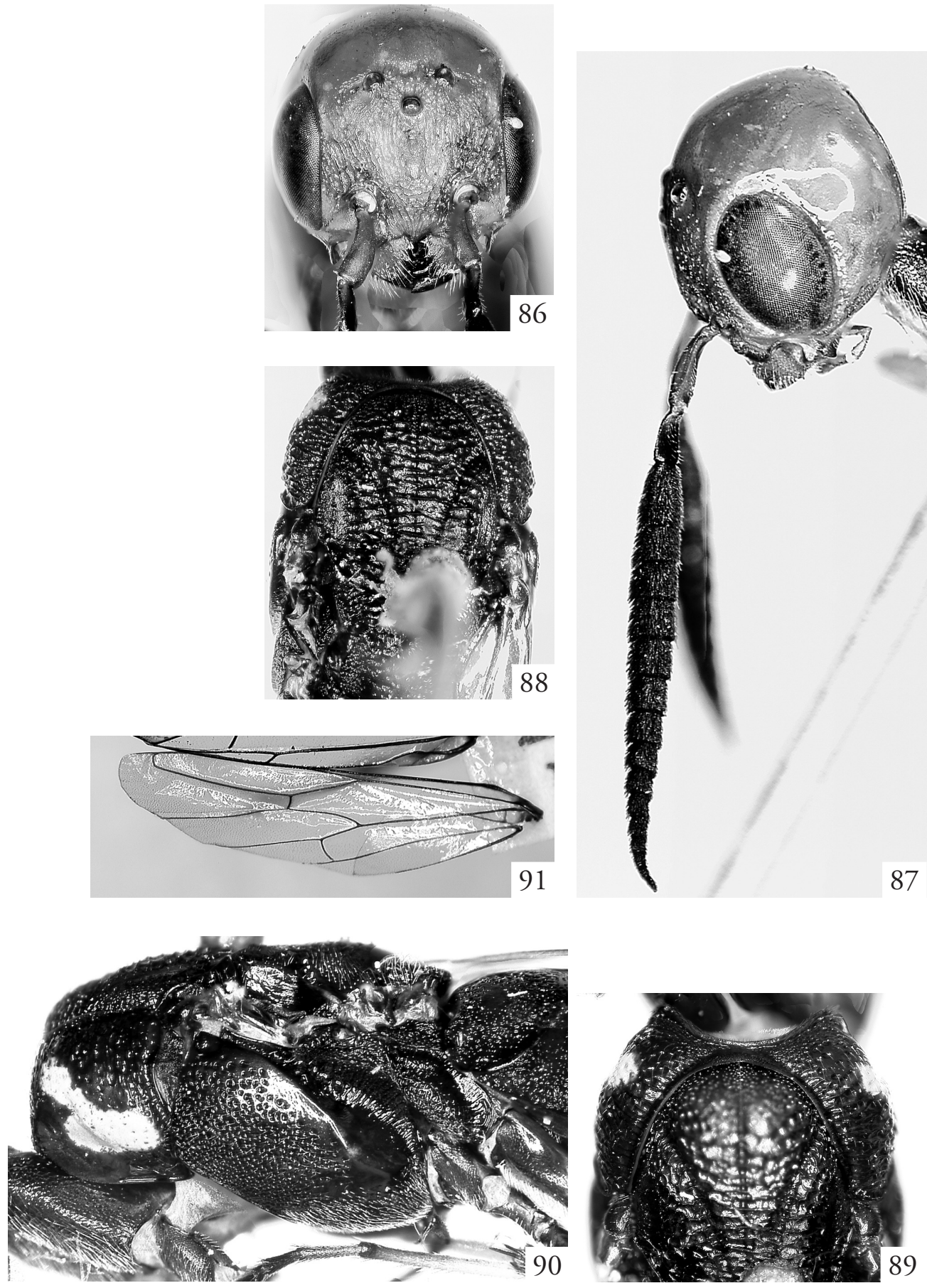

Figs 86-91: Obesaxiphyda borneensis, holotype 86 Head, front. 87 Head and antennae, lateral. 88 Thorax, dorsal. 89 Thorax, anterodorsal, showing pronotal collar. 90 Thorax lateral. 91 Hind wing. 

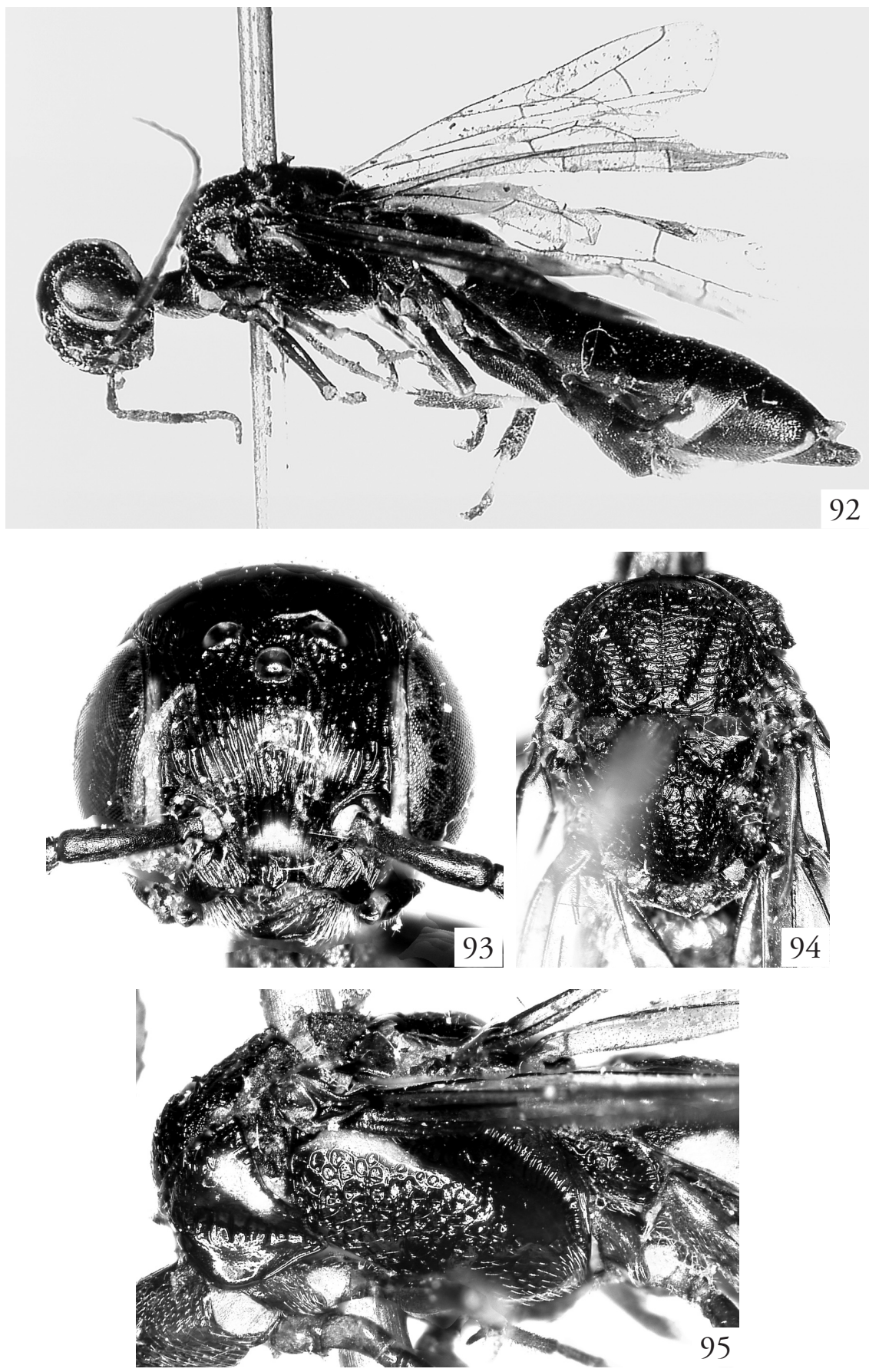

Figs 92-95: Hyperxiphia cyanea, holotype. 92 Lateral. 93 Head, front. 94 Thorax, dorsal. 95 Thorax, lateral. 

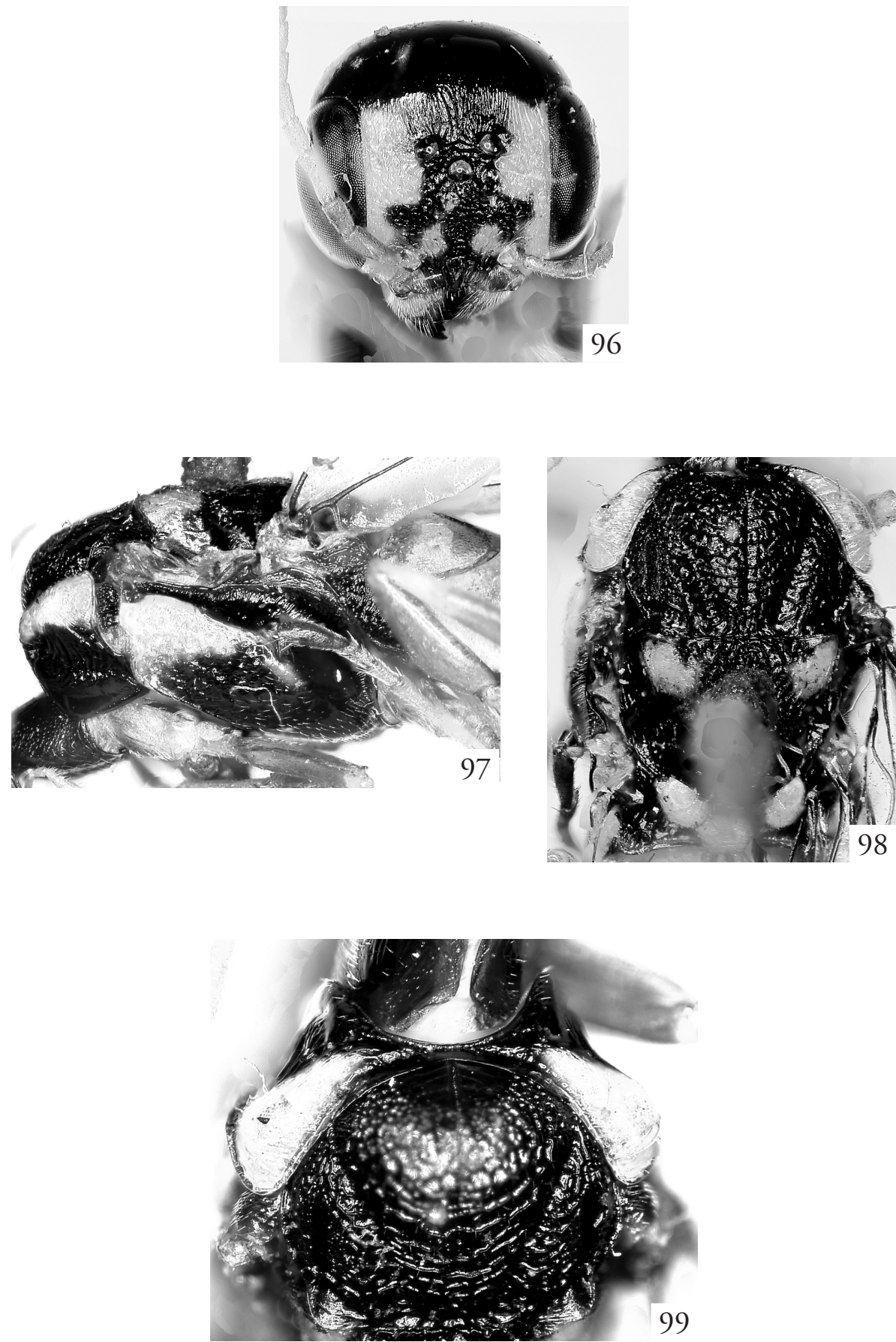

Figs 96-99: Hyperxiphia flavicornis, holotype. 96 Head, front. 97 Thorax, lateral. 98 Thorax, dorsal. 99 Thorax anterodorsal, showing pronotal collar. 

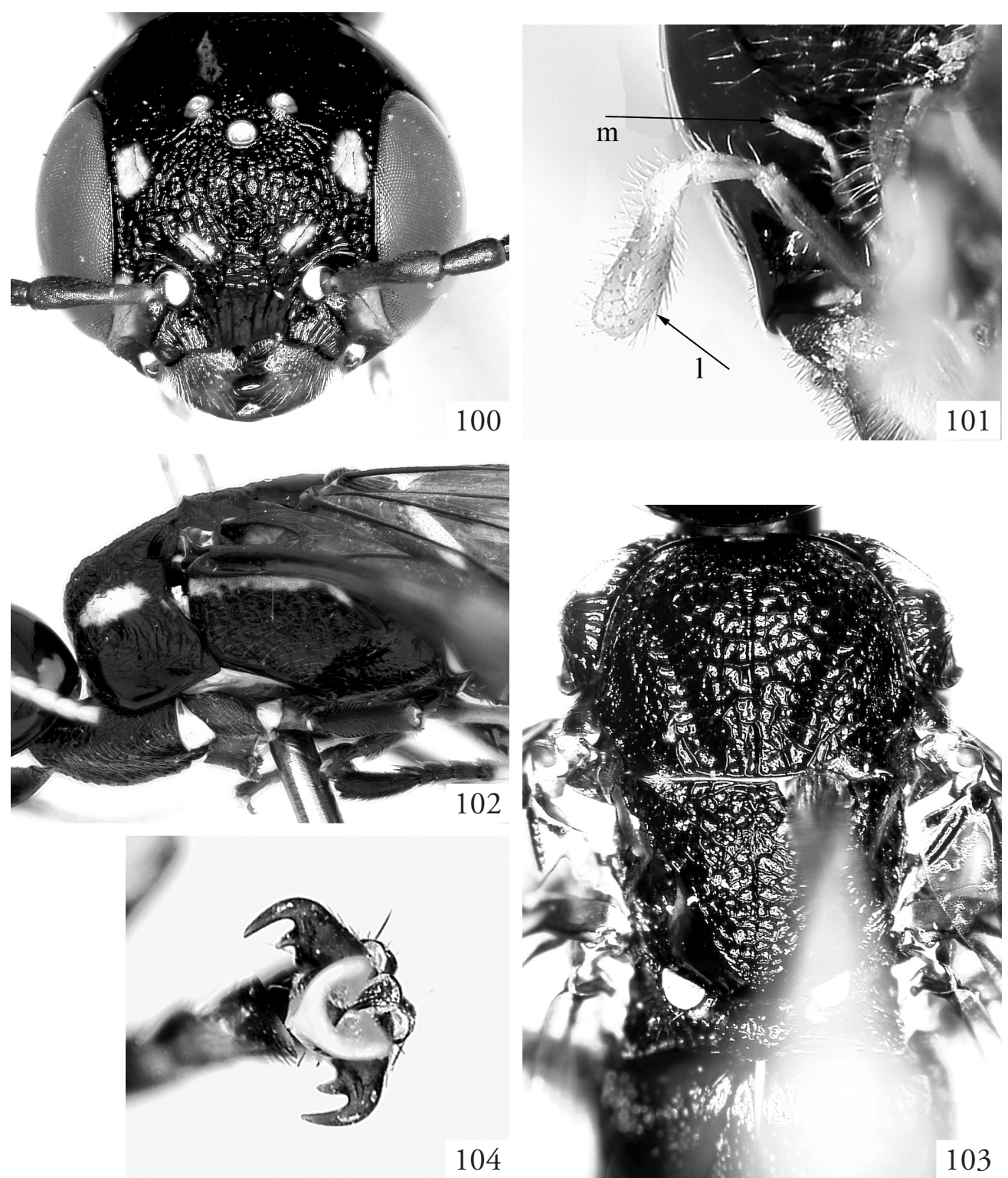

Figs 100-104: Hyperxiphia sulawesi, holotype. 100 Head, front. 101 Mouthparts, maxillary palpus above, labial palpus below. 102 Thorax, lateral. 103 Thorax, dorsal. 104 Hind tarsal claws. 


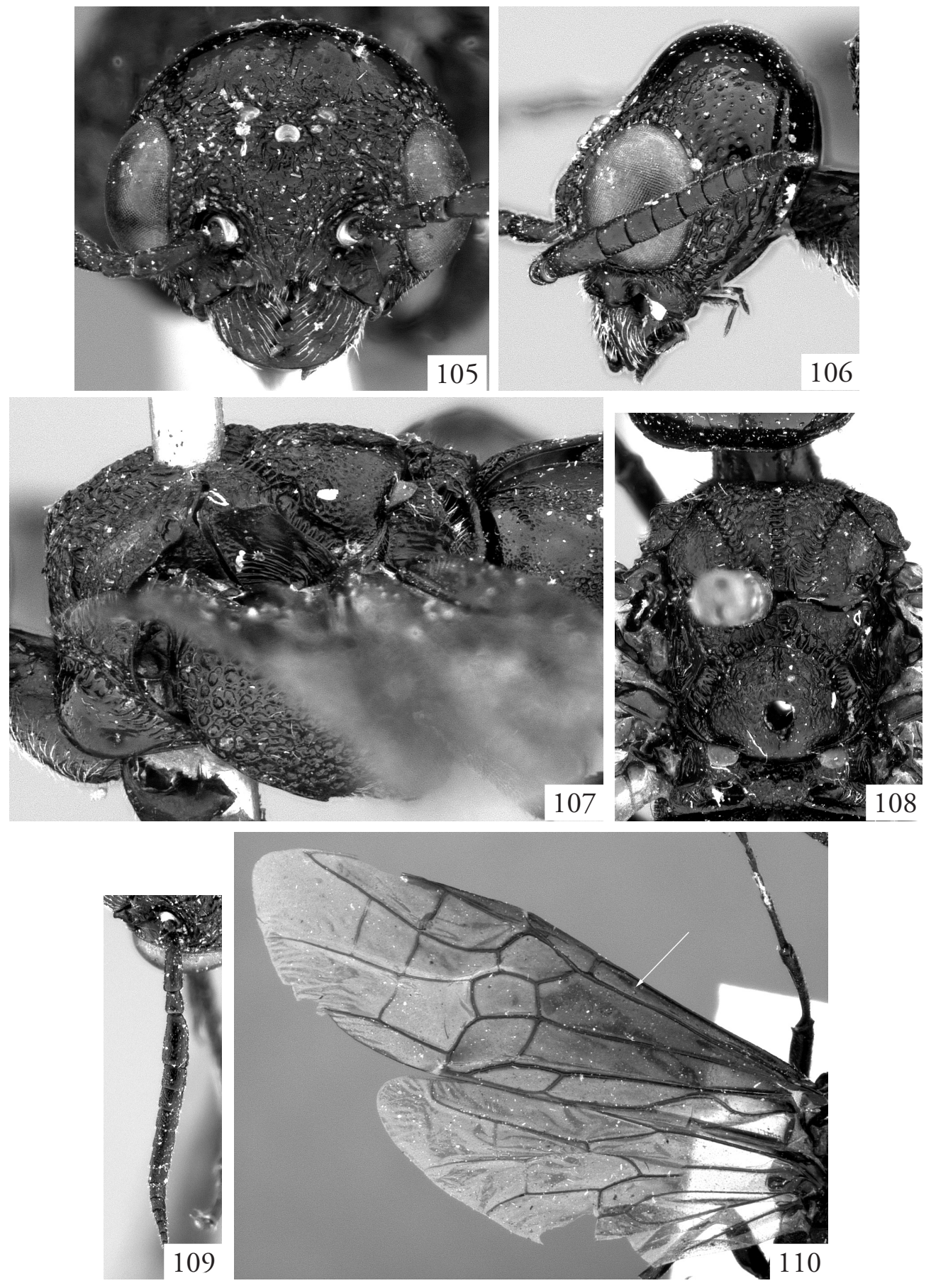

Figs 105-110: Lataxiphyda erythropus, holotype of X. melanopus. $105 \mathrm{Head}$, front. $106 \mathrm{Head}$ and pronotum, lateral. 107 Thorax, lateral. 108 Thorax, dorsal. 109 Female antenna. 110 Wings; arrow points to costal cell. 

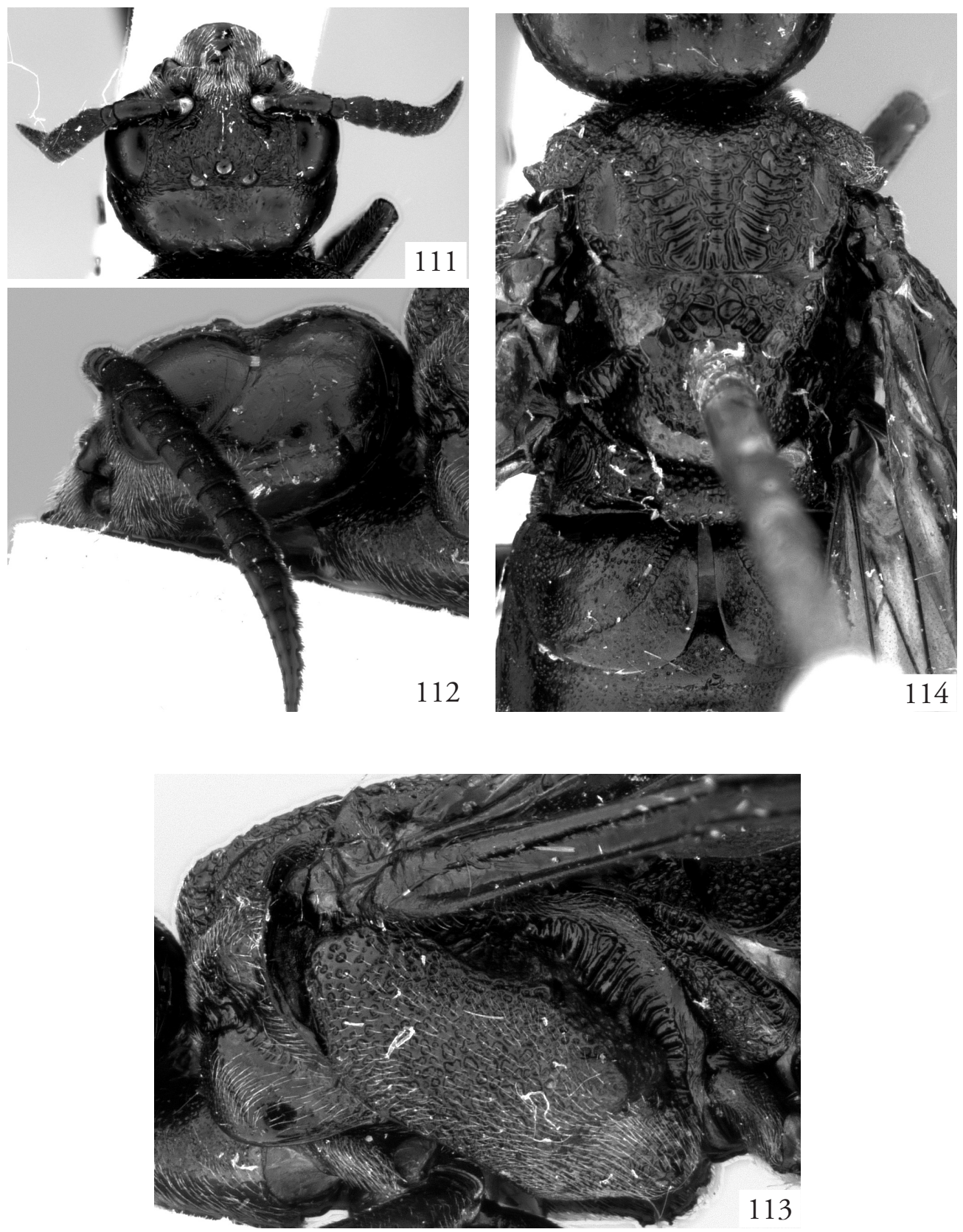

Figs 111-114: Lataxiphyda paraerythropus. 111 Head, front. 112 Head, lateral. 113 Thorax, lateral. 114 Thorax, dorsal. 

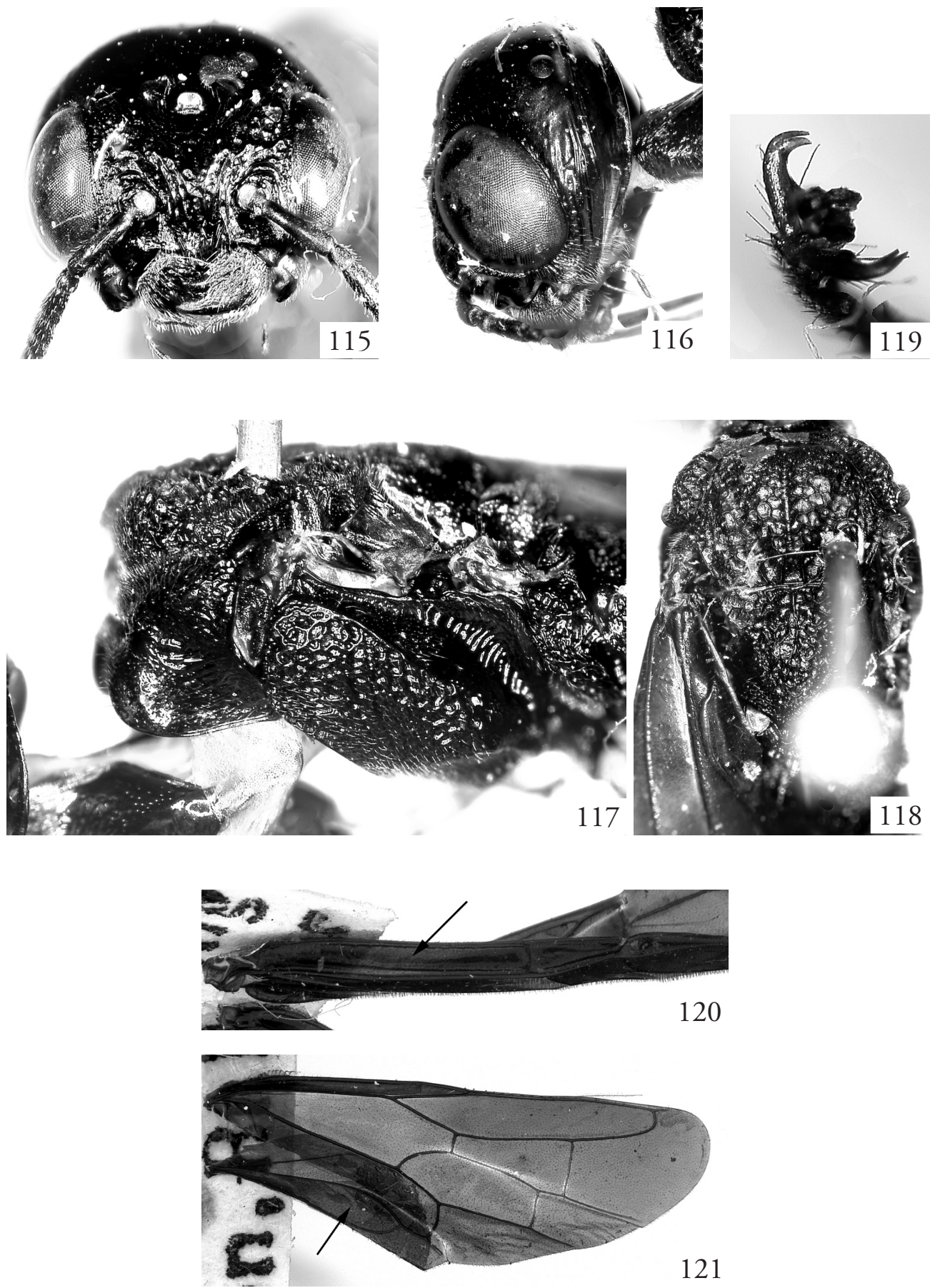

Figs 115-121: Lataxiphyda pyrura, holotype. 115 Head, front. 116 Head, lateral. 117 Thorax, lateral. 118 Thorax, dorsal. 119 Hind tarsal claws. 120 Anterior of forewing, showing broad costal cell (rest of wing folded under). 121 Hind wing; arrow points to costal cell. 